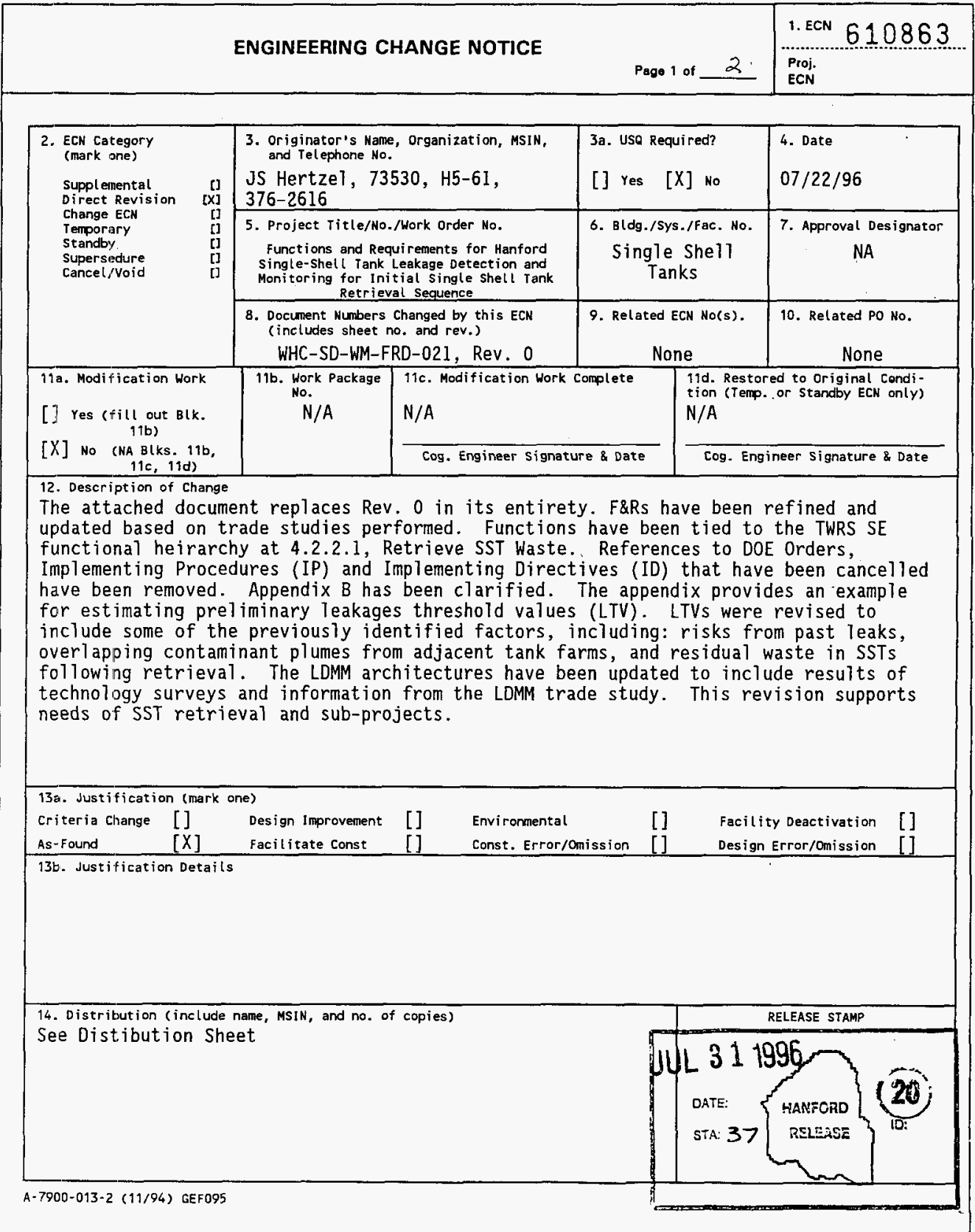




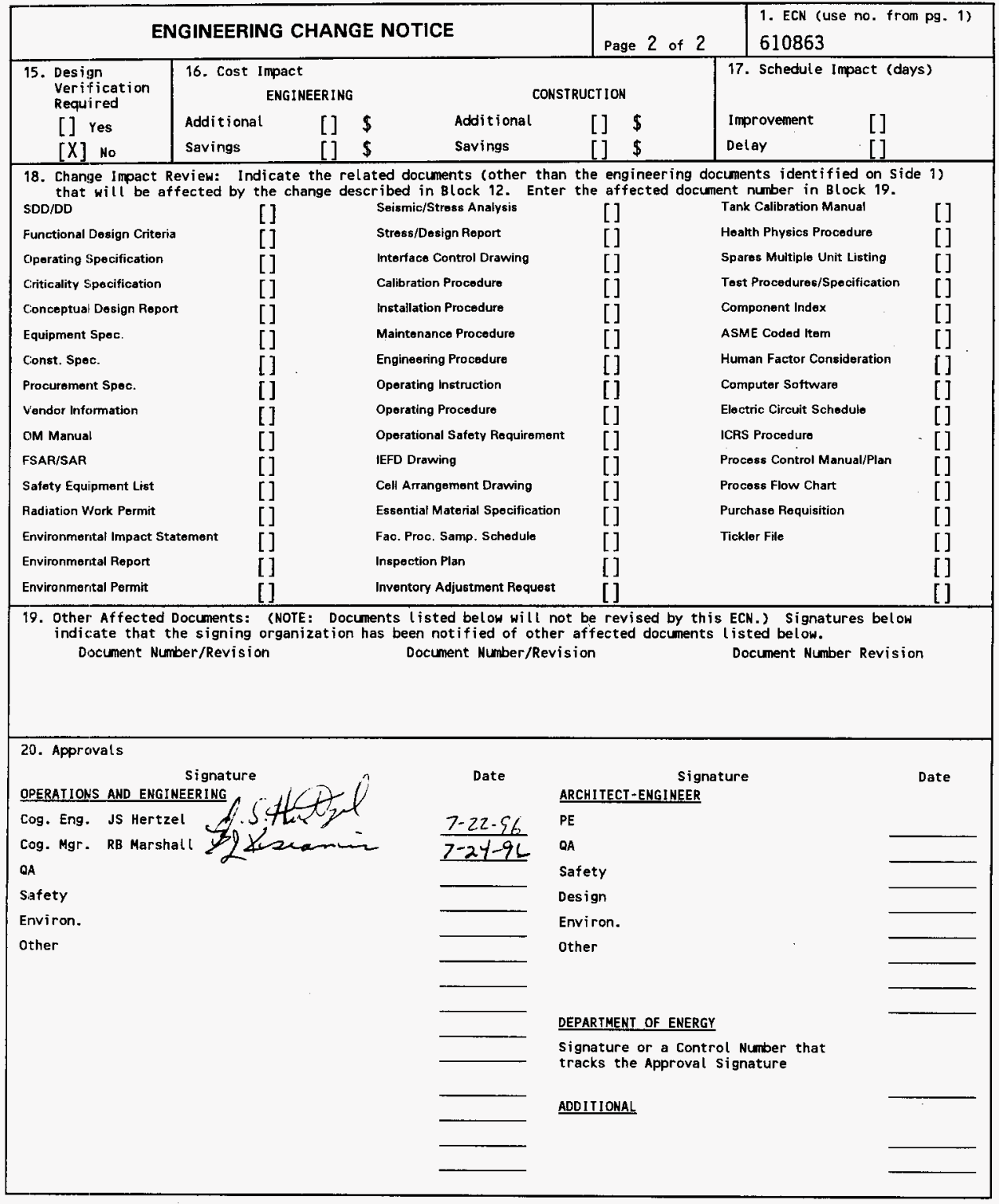




\title{
Functions and Requirements for Hanford Single- Shell Tank Leakage Detection and Monitoring
}

\author{
D.F. Iwatate \\ Westinghouse Hanford Company, Richland, WA 99352 \\ U.S. Department of Energy Contract DE-ACO6-87RL10930
EDT/ECN: $610863 \quad$ UC: 2030
Org Code: 74410 Charge Code: D2045
B\&R Code: EW3130010 Total Pages: 113

Key Words: Functions, Requirements, Initial Single-She11 Tank Retrieval Sequence, Systems engineering

Abstract: This document applies the System Engineering process to define the functions and requirements for single shel1 tank (SST) leakage detection, monitoring and mitigation during the initial SST retrieval sequence.

TRADEMARK DISCLAIMER. Reference herein to any specific comercial product, process, or service by trade name, trademark, manufacturer, or otherwise, does not necessarily constitute or imply its endorsement, recomendation, or favoring by the United States Government or any agency thereof or its contractors or subcontractors.

Printed in the United States of America. To obtain copies of this document, contact: WHC/BCS Document Control Services, P.O. Box 1970, Mailstop H6-08, Richland WA 99352, Phone (509) 372-2420; Fax (509) 376-4989.
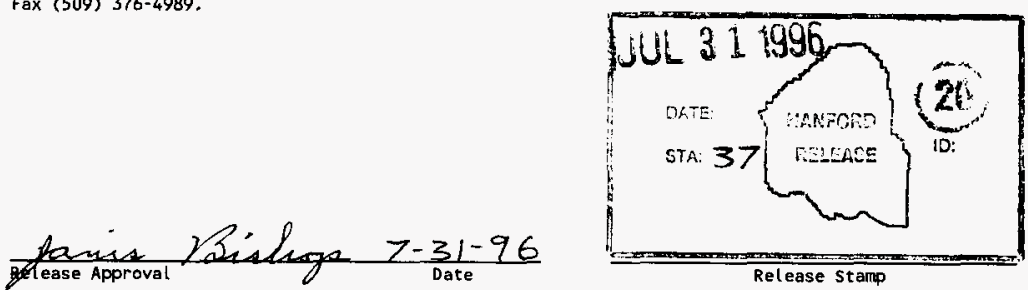

\section{Approved for Public Release}


(2) Title

Functions and Requirements for Hanford Single-shel1 Tank Leakage Detection and Monitoring for Initial Single-shell Tank Retrieval Sequence

CHANGE CONTROL RECORD

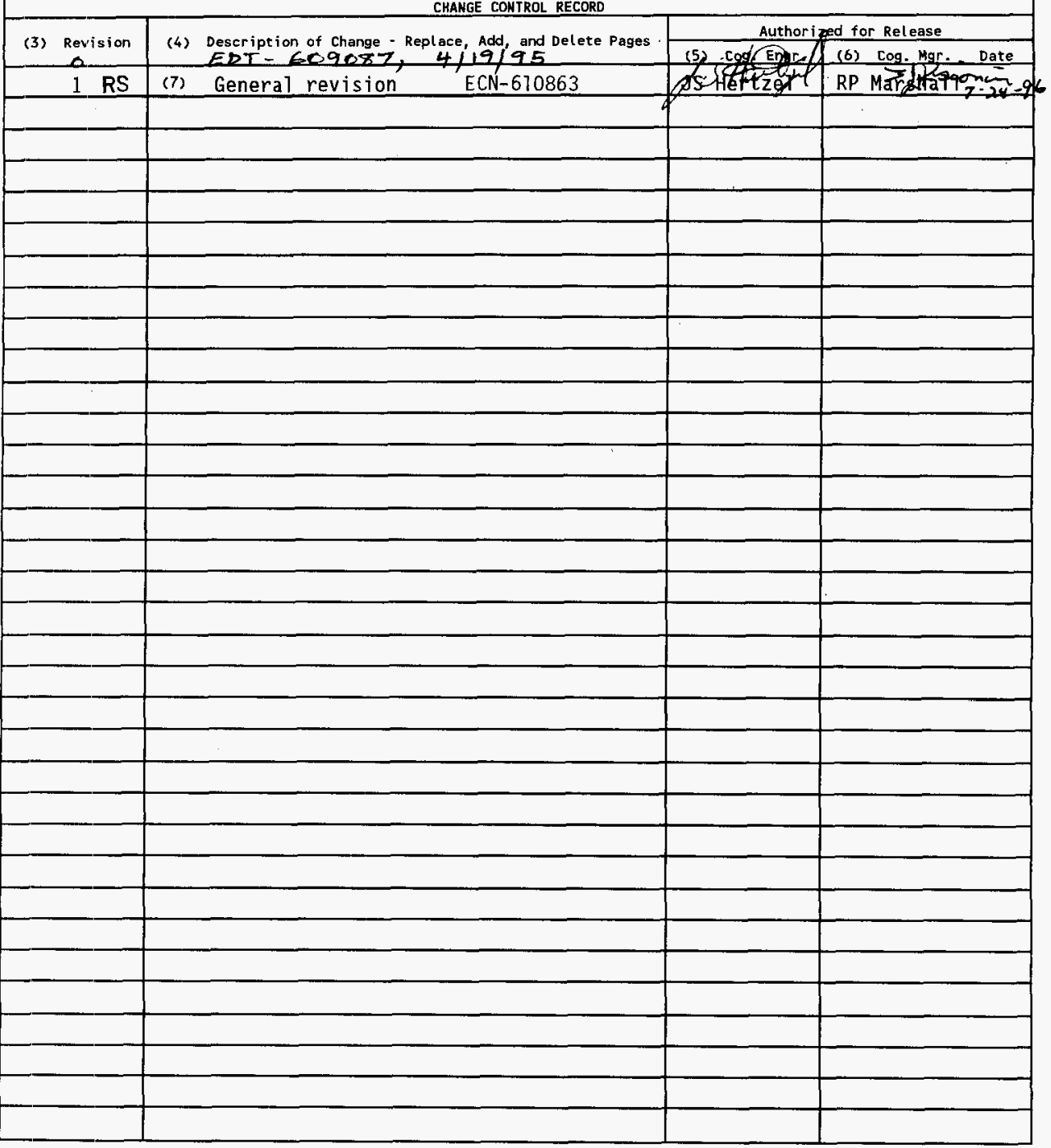




\section{Functions and Requirements for Hanford Single-Shell Tank Leakage Detection and Monitoring}

WHC-SD-WM-FRD-021

Revision 1

April 1996

Prepared for

Westinghouse Hanford Company

Tank Waste Remediation System

Task 015 of Order No. MGK-SVV-186918

Prepared by

Foster Wheeler Environmental Corporation

1981 Snyder Road, Suite 3

Richland, WA 99352 
WHC-SD-WM-FRD-021 REV. 1

This page intentionally left blank. 


\section{CONTENTS}

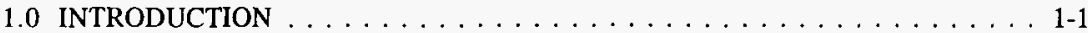

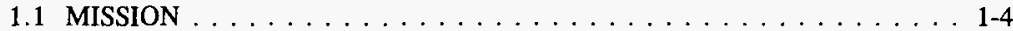

1.2 SCOPE . . . . . . . . . . . . . . . . 1-5

1.3 BACKGROUND INFORMATION $\ldots \ldots \ldots \ldots \ldots \ldots \ldots \ldots \ldots$

1.3.1 Single-Shell Tank Physical Description $\ldots \ldots \ldots \ldots \ldots \ldots$ 1-7

1.3.2 Single-Shell Tank Waste Description . . . . . . . . . . . 1-8

1.3.3 Hanford Site Geology . . . . . . . . . . . . . . . . . . . . . 1-9

1.4 FUNCTIONS AND REQUTREMENTS DOCUMENT . . . . . . . . . 1-10

2.0 FUNCTIONS AND REQUIREMENTS $\ldots \ldots \ldots \ldots \ldots \ldots \ldots \ldots \ldots$ 2-1

2.1 FUNCTION HIERARCHY $\ldots \ldots \ldots \ldots \ldots \ldots \ldots \ldots \ldots . \ldots \ldots . \ldots \ldots$

2.2 FUNCTION DESCRIPTION SHEETS $\ldots \ldots \ldots \ldots \ldots \ldots \ldots$. . . . . . . .

3.0 ARCHITECTURE . . . . . . . . . . . . . . . . . . 3-1

3.1 ARCHITECTURE HIERARCHY . . . . . . . . . . . . 3-1

3.2 ARCHITECTURE DESCRIPTION SHEETS $\ldots \ldots \ldots \ldots \ldots \ldots$. . . . . . .

4.0 REFERENCES . . . . . . . . . . . . . . . . . 4-1

\section{APPENDICES}

A GENERAL REQUIREMENTS APPLICABLE TO TANK FARMS $\ldots \ldots \ldots \ldots$ A-i

B EXAMPLE RISK-BASED LEAKAGE THRESHOLDS FOR

HANFORD SITE SINGLE-SHELL TANKS $\ldots \ldots \ldots \ldots \ldots \ldots \ldots$. $\ldots \ldots$-i

C ITEMS NEEDING FURTHER RESOLUTION $\ldots \ldots \ldots \ldots \ldots \ldots \ldots \ldots$ C-i 


\section{LIST OF FIGURES}

1-1 SST Leakage Detection and Monitoring Zones $\ldots \ldots \ldots \ldots \ldots$. . . . . . . . . .

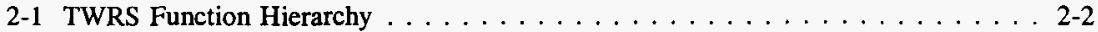

2-2 SST Waste Retrieval LDMM Function Hierarchy $\ldots \ldots \ldots \ldots \ldots . \ldots . . . . . .2-3$

3-1 SST Waste Retrieval LDMM Architecture Hierarchy . . . . . . . . . . . 3-2

\section{LIST OF TABLES}

2-1 SST Leakage Detection, Monitoring, and Mitigation Requirements Allocation . . . 2-4 
WHC-SD-WM-FRD-021 REV. 1

\section{LIST OF TERMS}

$\begin{array}{ll}\text { ALARA } & \text { as low as reasonably achievable } \\ \text { ARAR } & \text { Applicable or Relevant and Appropriate Requirement } \\ \text { CERCLA } & \text { Comprehensive Environmental Response, Compensation, and Liability Act } \\ \text { COC } & \text { constituent of concern } \\ \text { CY } & \text { calendar year } \\ \text { DOE } & \text { U.S. Department of Energy } \\ \text { DST } & \text { double-shell tank } \\ \text { Ecology } & \text { Washington State Department of Ecology } \\ \text { ENRAF } & \text { Automatic Level Gauge - Enraf-Nonius } \\ \text { EPA } & \text { U.S. Environmental Protection Agency } \\ \text { ERT } & \text { electrical resistivity tomography } \\ \text { FIC } & \text { Automatic Level Gauge - Food Instrument Corp. } \\ \text { HI } & \text { hazard index } \\ \text { ID } & \text { identification } \\ \text { ISSTRS } & \text { Initial Single-Shell Tank Retrieval System } \\ \text { LDMM } & \text { leakage detection, monitoring, and mitigation } \\ \text { LTV } & \text { leakage threshold value } \\ \text { MCL } & \text { maximum contaminant level } \\ \text { MTCA } & \text { Model Toxics Control Act } \\ \text { NRC } & \text { U.S. Nuclear Regulatory Commission } \\ \text { PP/EP } & \text { Plio-Pleistocene/early Palouse } \\ \text { RCRA } & \text { Resource Conservation and Recovery Act } \\ \text { RL } & \text { U.S. Department of Energy, Richland Operations Office } \\ \text { RQ } & \text { reportable quantity } \\ \text { SST } & \text { single-shell tank } \\ \text { TBD } & \text { to be determined } \\ \text { TC } & \text { toxicity characteristic } \\ \text { TDR } & \text { time domain reflectometry } \\ \text { Tri-Party } & \\ \text { Agreement } & \text { Hanford Federal Facility Agreement and Consent Order } \\ \text { TSD } & \text { treatment, storage, and disposal } \\ \text { TWRS } & \text { Tank Waste Remediation System } \\ \text { WHC } & \text { Westinghouse Hanford Company } \\ & \end{array}$


WHC-SD-WM-FRD-021 REV. 1

This page intentionally left blank. 


\subsection{INTRODUCTION}

This document applies the Systems Engineering process to define the functions and requirements for single-shell tank (SST) leakage detection, monitoring, and mitigation (LDMM) during SST waste retrieval. A function is defined as the system of accomplishments required to meet the overall mission; a requirement is defined as a qualitative or quantitative statement of how well a function must be performed. Within the Tank Waste Remediation System (TWRS), requirements may be either constraints or performance requirements. Constraints are imposed on the function by the external environment (e.g., U.S. Congress, U.S. Environmental Protection Agency (EPA), Washington State Department of Ecology (Ecology), or U.S. Department of Energy (DOE) Orders. Performance requirements are imposed on the function by the TWRS program and may be traded with respect to other performance requirements to optimize overall performance.

This document does not present the "final" version for incorporation into the TWRS systems engineering process. The process that will prepare this information for formal entry into the systems engineering database will use this document as a primary reference. The functional analysis and requirements analysis results, when verified and approved, will be placed under Configuration Management as part of the TWRS program integrated baseline. All information associated with functional analysis and requirements analysis will be entered into the Requirements Management and Assured Compliance System (RMACS). RMACS, the primary systems engineering tool, will be used as the central repository for all functions, requirements, architectures, and supporting data. It will be used to generate specifications and test requirements and is used to provide top-to-bottom traceability of functions, requirements, architectures, and components (Peck 1996). Only minor changes in the content of this document are expected at that time, in order to ensure that LDMM is addressed in the context of all TWRS systems engineering interfaces. The information in this document also supports design information needs for the Initial Single Shell Tank Retrieval System (ISSTRS) and completion of a Hanford Federal Facility Agreement and Consent Order (Tri-Party Agreement) target date deliverable "T02" in the M45 series of TriParty Agreement TPA milestones (M45-08-T02, due April 1997).

\section{Changes in This Revision}

This document revision (Revision 1) is a major update of the Revision 0 Functions and Requirements for Hanford Single-Shell Tank Leakage Detection and Monitoring (Cruse et al. 1995). This revision supports the needs of the SST Retrieval System and subprojects. The previous revision included functions and requirements for leakage detection and monitoring related to waste storage, tank closure, and waste retrieval. Revision 1 now includes only functions and requirements for waste retrieval. This revision also incorporates functions and requirements for SST leakage mitigation that were adapted from Functional Requirements for Single-Shell Tank Leakage Mitigation (Cruse 1994). The functions and requirements hierarchy was updated to match the current TWRS functions and requirements. 
The LDMM architecture provided in Section 3 was updated to include the results of two technology surveys (Lewis and Teel 1994; Lewis et al. 1995) and an LDMM trade study (Foster Wheeler 1996). Based on information needs identified in these studies, additional performance requirements were added to Section 2 .

The previous revision included an example calculation of risk-based SST leakage threshold values (LTVs) that could be used to evaluate LDMM technologies and set performance guidelines. These LTVs are one way to determine a leakage value that can be provided to Retrieval Operations as a pre-operations, risk-based decision-making tool. The LTVs are not intended to be used as a method of restricting retrieval, but rather they are intended as a tool for determining parameters within which to work during retrieval. In the previous revision, three considerations were identified (but not pursued) as necessary to make the LTVs more defensible. These included (1) quality checks of the tank inventory and concentration data, (2) inclusion of additional risks associated with sources other than new leakage (e.g., residual waste in tanks following retrieval, waste that has advected into the SST concrete structure, and past leaks), and (3) the presence of overlapping contaminant plumes from other sources (e.g., nearby tank farms, cribs, trenches, and ponds).

In this new revision, the LTVs were revised to include some of the previously identified factors, including: risks from past leaks, overlapping contaminant plumes from adjacent tank farms, and residual waste in the SSTs following retrieval. Factors that were not considered in this revision include waste that has advected into the concrete structure and contaminant plumes from cribs, trenches, and ponds.

\section{Conclusions}

The analysis of functions and requirements and related work performed to date supports the following conclusions regarding LDMM.

- The TWRS baseline LDMM system is composed of technologies that are both available and deployable. The leakage detection component consists of liquid/waste level measurement devices inside the tank (i.e., mass balance) and leakage detection pits (where available). The leakage monitoring component consists of borehole logging. Improved equipment and operational, procedural, and administrative methods will be used to mitigate leakage during past-practice sluicing.

- The effects of transport time and lateral migration and the resultant mixing and/or superposition of contaminant plumes will render data obtained from the unsaturated and/or groundwater zones to be of very limited value for leakage detection during sluicing. 


\section{Issues Requiring Resolution}

- The tank closure strategy should include development of leakage thresholds based on a more comprehensive risk assessment and a decision logic to be implemented if the established thresholds are exceeded.

- The applicability of leakage detection technology depends on its sensitivity to detecting and measuring the volume of leakage, regardless of leakage location and size. The trade study of LDMM technologies to support SST waste retrieval (Foster Wheeler 1996) evaluated minimum and maximum leakage detection limits for sets of conditions most advantageous to detection and least advantageous to detection. Wide ranges of leak detection sensitivities were found for the LDMM technologies evaluated. Minimum leakage detection sensitivities appeared attractive in many cases but maximum leakage detection sensitivities were often unacceptably high. No attempt was made to evaluate the probabilities of various leakage locations, sizes, and probabilities to enable prediction of a most-likely leakage detection volume. It was suggested that design-basis leakage conditions be established, including probabilities of occurrence. The probability-weighted effectiveness of the technologies should then be determined and compared to the effectiveness of the baseline LDMM system.

- An example determination of risk-based SST LTVs are provided in Appendix $B$ and are intended only for use in initial technology evaluations. The values

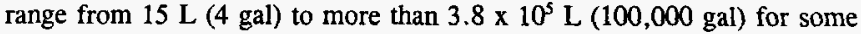
tanks. The criteria and approach used in this example calculation need to be refined and peer-reviewed before submittal to the regulators as proposed allowable leakage volume criteria. Alternative approaches to calculation of LTVs could include different points of compliance, different bases for allowable public and worker risk, different assumptions regarding probable tank farm closure, or different assumptions regarding the exposed individual or population.

An example of an alternate approach is to base LTVs on the risk resulting to an individual that uses the Columbia River as a source for drinking water. The LTVs resulting from such a scenario may be less restrictive than those provided in Appendix B (which involved an individual using groundwater from beneath the tanks farms for drinking, crop irrigation, and animal watering).

The LTVs developed in Appendix B are suitable for initial technology evaluations; however, final LTVs developed for SST waste retrieval activities must be made case-by-case and revised as waste retrieval proceeds in each tank farm. Some areas that should be further evaluated to develop LTVs for SST waste retrieval include the following. 
1. The LTV calculations were based on the assumption that all leakage from the SSTs would contain constituents of concern at concentrations equal to the composition of the tank-specific interstitial liquor. These data were developed for individual tanks based on tank-specific characterization data and simplifying assumptions. The LTVs for all of the SSTs in the B, BX, and BY Tank Farms are quite low and definitely below the leakage detection limits for the baseline LDMM system, indicating that sensitive leakage detection would be required if these values were to be applied as operational ceilings for leakage. The LTVs should be evaluated on a case-by-case basis after waste retrieval operations are underway; e.g., if the tank farm LTV was originally calculated based on the assumption that six tanks would leak and only four tanks actually leaked during retrieval, the LTV would need to be recalculated.

2. Further analyses of drainable liquid samples are required to reduce uncertainty and conservatism. The sample data reported in Van Vleet (1993) were used as a primary source for this document; however, Van Vleet (1993) is considered to be outdated and contains several errors. Accordingly, the next phase of evaluation should include work to ensure the correctness and completeness of the sample data supporting the leakage thresholds.

3. The inventories of COCs associated with sources other than new leakage (e.g., residual waste in tanks following retrieval, waste that has advected into the SST concrete structure, and past leaks) should be reviewed to ensure assumed inventories are consistent with current data.

4. The presence of overlapping contaminant plumes from other sources may increase risk. These sources, including nearby cribs, trenches, and ponds, should be considered to help establish the appropriate allocation of risk from each source.

\subsection{MISSION}

The mission of the TWRS program is to store, treat, and immobilize highly radioactive Hanford waste in an environmentally sound, safe, and cost-effective manner. The scope of the TWRS program includes project and program activities for receiving, storing, maintaining, treating, and disposing onsite, or packaging for offsite disposal, all Hanford Site tank waste. Hanford Site tank waste includes the contents of 149 SSTs and 28 double-shell tanks (DSTs), any new waste added to these facilities, and all encapsulated cesium and 
strontium stored onsite and returned from users offsite. A key element of the TWRS program is retrieval of the waste in the SSTs. The waste stored in these underground tanks must be removed in order to minimize environmental, safety, and health risks associated with continued waste storage.

Past-practice hydraulic sluicing is the first choice reference retrieval technology where tank leakage is not a problem (Gibbons et al. 1993). The sluicing operations will typically add some level of working liquid to the tank to mobilize the solidified saltcakes and sludges. 'The design life of the tanks has expired and the integrity of the tank containment boundaries is questionable. Historically, tank wastes have been released to the ground from cascade tank discharges, leaks from SSTs and associated transfer lines, and other miscellaneous spills. According to the Tank Farm Surveillance and Waste Status Summary Report for October 1995,67 SSTs are assumed to have leaked a total volume of approximately 2,271 to 3,407 $\mathrm{m}^{3}$ (600,000 to $900,000 \mathrm{gal}$ ) (Hanlon 1996).

The Hanford Site SST farms were constructed from 1943 to 1964 . Retrieval of waste from the SSTs currently is scheduled for a 15-year processing campaign beginning in 2003 and ending in 2018, except Tank 241-C-106, which is planned for retrieval in 1997 to provide a demonstration of retrieval technology. Accordingly, the SSTs will be 60 to 75 years old at the initiation of retrieval. Detection and mitigation of new leakage and monitoring of existing leaks during the waste retrieval will be required to ensure that a goal of minimal achievable leakage can be achieved.

\subsection{SCOPE}

Leakage detection, monitoring, and mitigation is invoked in the TWRS program in four third-level functions: (1) manage tank waste, (2) retrieve tank waste, (3) process waste, and (4) dispose waste (as identified in Tank Waste Remediation System Functions and Requirements Document [WHC 1996]). The functions and requirements in this document apply to detection, monitoring, and mitigation of belowground leaks from SST containment boundaries and the resulting soil contamination during the retrieval phase.

The SST LDMM activities generally apply to three zones of influence in the environment surrounding a given tank farm: (1) near-field, (2) unsaturated, and (3) groundwater. Figure 1-1 depicts each zone and definitions are provided below.

- Near-Field Zone. The near-field zone is a cylindrical volume with a vertical centerline corresponding to the tank vertical centerline. This zone includes the internal tank volume, the tank liner, and the tank concrete shell. The nearfield zone extends from the exterior surfaces of the tank and/or ancillary equipment structures radially outward to include the existing drywells. The top of the cylinder is at grade level and the bottom extends downward to include any backfilled soil, lateral drywells, or leakage detection pits. The tank bottoms are approximately $15 \mathrm{~m}(50 \mathrm{ft})$ belowgrade. Allowing another 


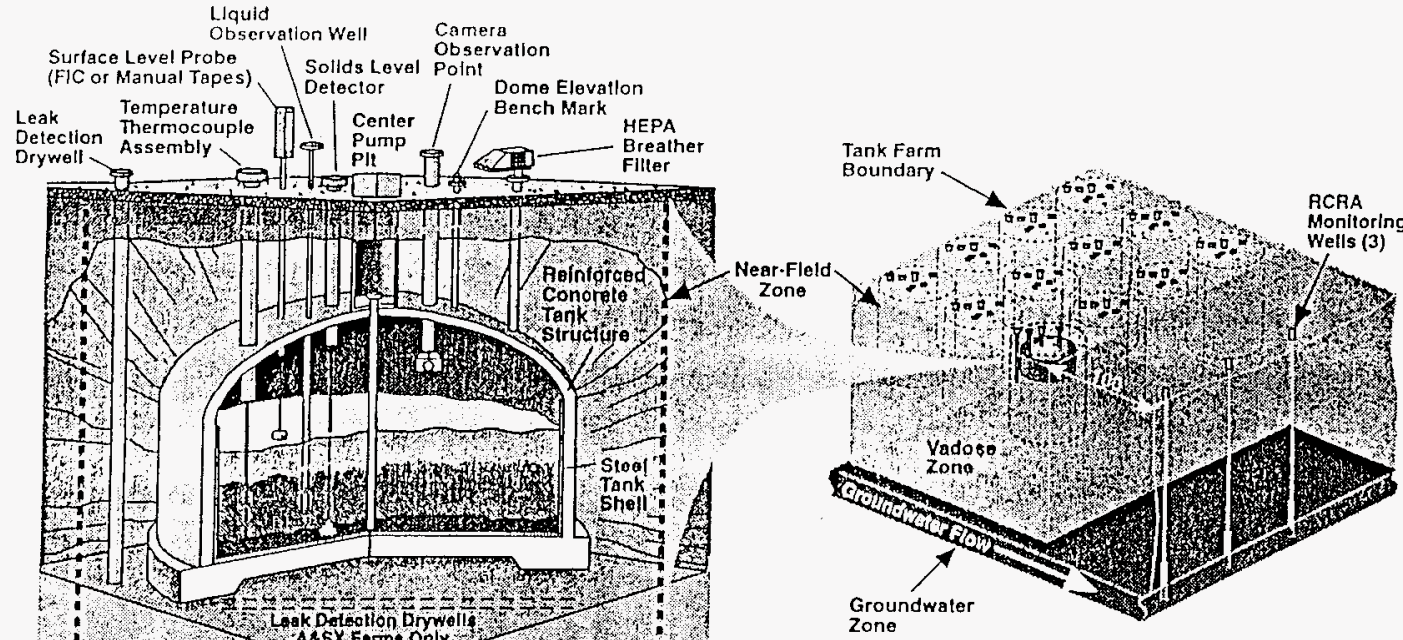

Figure 1-1. SST Leakage Detection and Monitoring Zones. 
$8 \mathrm{~m}(25 \mathrm{ft})$ to encompass any laterals or leakage detection pits gives a value of $23 \mathrm{~m}$ (75 ft) belowgrade for the bottom of the near-field zone. The diameter of the cylinder formed by the tank plus the volume needed to encompass the nearest drywells is typically $30 \mathrm{~m}(90 \mathrm{ft})$.

- Unsaturated Zone. The unsaturated zone is a soil volume formed by projecting the tank farm boundary from grade level downward to the unconfined aquifer, excluding the near-field zone. The distance from the tank bottoms to the groundwater is typically $80 \mathrm{~m}(240 \mathrm{ft})$.

- Groundwater Zone. The groundwater zone is any portion of the groundwater below the tank farm and/or downgradient of the tank farm that is potentially impacted by leakage from the tanks within the tank farm. The Resource Conservation and Recovery Act (RCRA) groundwater monitoring wells are installed, at a minimum, one upgradient and two downgradient from the major tank farm groups and are located a minimum of $33 \mathrm{~m}(100 \mathrm{ft})$ from the nearest tank farm boundary.

\subsection{BACKGROUND INFORMATION}

The waste status for the waste stored in underground tanks on the Hanford Site is provided in Hanlon (1996). This report is issued monthly and provides data on each of the underground waste storage tanks, and supplemental information regarding tank surveillance anomalies and ongoing investigations.

The geology of the Hanford Site is complex. Significant variations exist both locally and across the site as a whole. The most current descriptions and interpretations of the Hanford Site geology are provided in Delaney et al. (1991), Lindsey et al. (1992a), Lindsey et al. (1992b), and Reidel et al. (1992).

\subsubsection{Single-Shell Tank Physical Description}

There are 149 SSTs on the Hanford Site that contain radioactive and hazardous waste from the reprocessing of irradiated fuel elements that began in 1944. These underground storage tanks are grouped in 12 tank farms located in the 200 East and 200 West Areas.

There are 133 SSTs classified as 100 series tanks. Tanks in this series are $23 \mathrm{~m}(75 \mathrm{ft})$ in diameter with dome tops. Tank volumes are either $1,900 \mathrm{~m}^{3}(500,000 \mathrm{gal}), 2,800 \mathrm{~m}^{3}$ $(750,000 \mathrm{gal})$, or $3,800 \mathrm{~m}^{3}\left(1 \times 10^{6} \mathrm{gal}\right)$. These tanks have a minimum of $1.8 \mathrm{~m}(6 \mathrm{ft})$ of soil cover on the dome and a belowgrade invert elevation of $11 \mathrm{~m}$ to $15 \mathrm{~m} \mathrm{(37} \mathrm{to} 50 \mathrm{ft}$ ). The $1,900-\mathrm{m}^{3}(500,000-\mathrm{gal})$ and $2,800-\mathrm{m}^{3}(750,000-\mathrm{gal})$ tanks were originally arranged in cascades of three, four, or six tanks such that when the first tank in a cascade filled it overflowed to the next tank, and so on. The cascade arrangement allowed for overflow to 
the soil column. Tank farms with this arrangement include the B, BX, BY, C, S, T, TX, $T Y$, and $U$ Tank Farms. The $3,800-\mathrm{m}^{3}\left(1 \times 10^{6}\right.$-gal $)$ tanks are located in the $A, A X$, and SX Tank Farms.

The remaining 16 SSTs are classified as 200 series tanks. These tanks are $6 \mathrm{~m} \mathrm{(20} \mathrm{ft)} \mathrm{in}$ diameter with flat tops. Tank capacities are all $200 \mathrm{~m}^{3}(55,000 \mathrm{gal})$. The tanks all have a

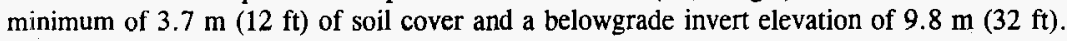
The tanks are arranged in groups of four and located in the B, C, T, and U Tank Farms.

Many of the SSTs have leaked or are assumed to have leaked in the past. An interim stabilization program to reduce the drainable liquid volumes from all SSTs is ongoing. To the extent possible, free liquid is pumped out of the SSTs to minimize the potential environmental impact in the event of a tank leak. Status of each of the SSTs and estimates of the leaked volumes are provided in Hanlon (1996).

\subsubsection{Single-Shell Tank Waste Description}

A total of $140,000 \mathrm{~m}^{3}\left(3.6 \times 10^{7} \mathrm{gal}\right)$ of waste is stored in the SSTs. About $2,300 \mathrm{~m}^{3}$ $(600,000 \mathrm{gal})$ is supernatant, $87,000 \mathrm{~m}^{3}\left(2.3 \times 10^{7} \mathrm{gal}\right)$ is salt cake, and $46,000 \mathrm{~m}^{3}$ $\left(1.2 \times 10^{7} \mathrm{gal}\right)$ is sludge (Hanlon 1996). The salt cake consists of the various salts formed from the evaporation of alkaline waste and is approximately $93 \mathrm{wt} \%$ sodium nitrate and sodium nitrite. The sludge consists of the solids (hydrous metal oxides) precipitated from the neutralization of acid waste before being transferred to the SSTs. On transfer of the evaporator slurry into the SSTs, some of the salt precipitated. As a result, roughly $50 \%$ of the reported sludge volume is salt cake. The liquid solution exists as supernatant and interstitial liquid in the tanks. An estimated $23,000 \mathrm{~m}^{3}\left(6 \times 10^{6} \mathrm{gal}\right)$ of drainable interstitial liquid is present in the SST salt cake and sludge (Hanlon 1996).

The SSTs primarily contain inorganic waste, although relatively small amounts of organic solvents were entrained during fuel reprocessing and some SSTs are on an organic watch list. Also, water-soluble complexing agents and citric acids added in the 221-B Plant fractionation process are in some SST wastes. A listing of all nonradioactive chemicals known to have been used at production plants and support facilities that transferred waste to the SSTs is documented in Inventory of Chemicals Used at Hanford Production Plants and Support Operations (1944-1980) (Klem 1990). Specific chemicals that may have been transferred to the SSTs and that appear on the "Dangerous Waste Sources List," WAC 173-303-9904, include carbon tetrachloride, methylene chloride, hexone, acetone, and ethyl ether. Chemical reactions (e.g., oxidation-reduction, neutralization, precipitation) and radiolysis may have converted many of these chemicals into other compounds with different physical and chemical properties (Camaioni et al. 1994).

Core samples have not yet been taken from all of the 149 SSTs. Hanford Federal Facility Agreement and Consent Order (Tri-Party Agreement) milestones have been established for characterizing the contents of the SSTs. Future funding plans give priority to waste 
characterization efforts. The transport of contaminants in the soil column to the groundwater depends on the soil chemistry and the mobility of key waste components will vary greatly under different conditions (e.g., alkaline, acidic, or organic).

\subsubsection{Hanford Site Geology}

The geology of the vadose zone beneath the tank farms is highly variable. In the 200 East Area the most important suprabasalt stratigraphic unit underlying the tank farms is the Hanford formation, Hanford formation strata also form an important part of the vadose zone beneath the tank farms in the 200 West Area. However, a significant part of the vadose zone in the 200 West Area also consists of units underlying the Hanford formation, the PlioPleistocene/early Palouse (PP/EP) interval and the Ringold Formation.

Throughout the 200 East and West Areas the Hanford formation is the uppermost stratigraphic unit underlying the tank farms. Hanford formation strata consist of uncemented gravel, sand, and silt deposited by Pleistocene cataclysmic flood waters. The Hanford formation varies from 60 to $90 \mathrm{~m} \mathrm{(200} \mathrm{to} 300 \mathrm{ft}$ ) thick in the 200 East Area and 30 to $45 \mathrm{~m}$ ( 100 to $150 \mathrm{ft}$ ) thick in the 200 West Area. Hanford deposits are divided into three facies that are gradational with each other and summarized as follows:

- Gravel-dominated facies: Generally consists of cross stratified, coarsegrained sand, and granule to boulder gravel that contain minor intercalated siltrich horizons. This facies generally is uncemented and matrix-poor, displays an open-framework texture, and has high saturated hydraulic conductivities.

- Sand-dominated facies: Well stratified, fine- to coarse-grained sand and granule to pebble gravel dominate. Silt content is variable, but where it is low an open-framework texture is common. Lenticular pebble gravel and silt interbeds may be present. Hydraulic conductivity values for this facies are dependant on silt content and as such are variable.

- Silt-dominated facies: Interbedded silt and fine- to coarse-grained sand forming well stratified fining upwards beds are characteristic. Perched water is common where this facies occurs because of the abundance of low hydraulic conductivity silt horizons.

In addition to the three facies, clastic dikes are also commonly found in the Hanford formation as well as locally in other sedimentary units in the Pasco Basin. These clastic dikes are structures that generally cross-cut bedding, although they do locally parallel bedding. The dikes usually consist of thin, alternating vertical to subvertical layers of silt, sand, and granules that can combine to form a dike several feet across. Where the dikes intersect the ground surface a feature known as patterned ground may be observed. Clastic dikes may act as both barriers to lateral flow as well as conduits for vertical flow depending on their composition. 
Strata comprising the PP/EP interval and the Ringold Formation form the lower half of the vadose zone in the 200 West Area. In addition, Ringold Formation deposits locally comprise the lowermost few tens of feet of the vadose zone in the 200 East Area. The PP/EP interval underlies the Hanford formation beneath most of the 200 West Area. It is up to approximately $12 \mathrm{~m} \mathrm{(40} \mathrm{ft)} \mathrm{thick} \mathrm{and} \mathrm{consists} \mathrm{of} \mathrm{(1)} \mathrm{lenticular} \mathrm{beds} \mathrm{of} \mathrm{uncemented} \mathrm{silt,} \mathrm{sand,}$ and gravel, (2) calcium carbonate lenses and concretions, and (3) calcium carbonate and silica cemented sands and gravels. Perched water can occur locally on silt-rich and cemented zones within the PP/EP interval.

Ringold Formation strata in the 200 East and West Areas are dominated by partially consolidated to cemented, clast to matrix supported, pebble to cobble gravels with a fine- to coarse-grained sand matrix. Localized sand-rich intervals also occur in the Ringold Formation. Silt content in Ringold gravels and sands generally is low $(<5 \%)$, although the presence of cementation and local silt-rich zones may produce perched water conditions. About 15 to $27 \mathrm{~m}$ (50 to $90 \mathrm{ft}$ ) of Ringold strata occur in the vadose zone in the 200 West Area.

\subsection{FUNCTIONS AND REQUIREMENTS DOCUMENT}

Functions are specific actions or processes that achieve or support the achievement of objectives (i.e., what must be done). Requirements are criteria that set acceptable limits on functions and their products (i.e., how well a function must be performed). Architectures represent a strategy, a process, or a piece of the actual physical system that satisfies a corresponding requirement (i.e., how a function will be performed).

A mission analysis defines the function that a system as a whole must perform. This toplevel function can be decomposed into subfunctions that are both necessary and sufficient to accomplish the mission. Requirements may be general in nature and apply to an entire system, or they may themselves be decomposed and allocated to subfunctions at a lower level.

This document describes the functions to be performed by SST LDMM systems based on their role in supporting retrieval of the SST wastes, and to identify the requirements that constrain their application. These functions and requirements together define the functional baseline for SST LDMM systems. 


\subsection{FUNCTIONS AND REQUIREMENTS}

The TWRS Systems Engineering fifth-level function of Remove Limited SST Waste (as of January 19, 1996) was broken down into its component functions, which are described in the following sections. These functions, requirements, and interfaces will be used to facilitate further development of alternative design concepts. This further development is described in Section 3, Architecture.

The TWRS Systems Engineering process includes identifying functions, identifying requirements, identifying possible architectures (alternatives), and performing trade studies. As each step in the process is completed, the other steps are reevaluated in an iterative manner, and revised if necessary, to maintain continuity with the overall TWRS functions and requirements. This process is completed when the final architecture meets all requirements for the identified functions, and is approved.

The functions and requirements defined in the following sections are intended to focus on function-specific items. The items address requirements for safe conduct of operations, as low as reasonably achievable (ALARA) radiation protection, environmental and regulatory compliance, design of systems, and other items applicable to SST Retrieval LDMM operations in the Hanford Site tank farms. General requirements regarding development and implementation of new systems (i.e., regardless of function) in the tank farms are not included to avoid unnecessary repetition. Appendix A provides a summary of the applicable general requirements. Appendix $\mathbf{C}$ is a list of the items needing further resolution.

\subsection{FUNCTION HIERARCHY}

Each function identified for SST Retrieval LDMM is given a unique number to represent the function's position in the TWRS Function Hierarchy. Figure 2-1 shows the hierarchy of the TWRS functions to the fourth level. Figure 2-2 illustrates the hierarchy of the SST Retrieval LDMM functions, as decomposed from the higher level TWRS functions. Table 2-1 provides the requirements allocation, arranged by requirement.

\subsection{FUNCTION DESCRIPTION SHEETS}

A Function description sheet is provided for each of the functions identified for SST Retrieval LDMM during retrieval. The function description sheets provide the function definitions, enabling assumptions, interfaces, and function requirements. The function description sheets provide discussion of performance requirements for alternatives to establish - a basis for evaluation. 


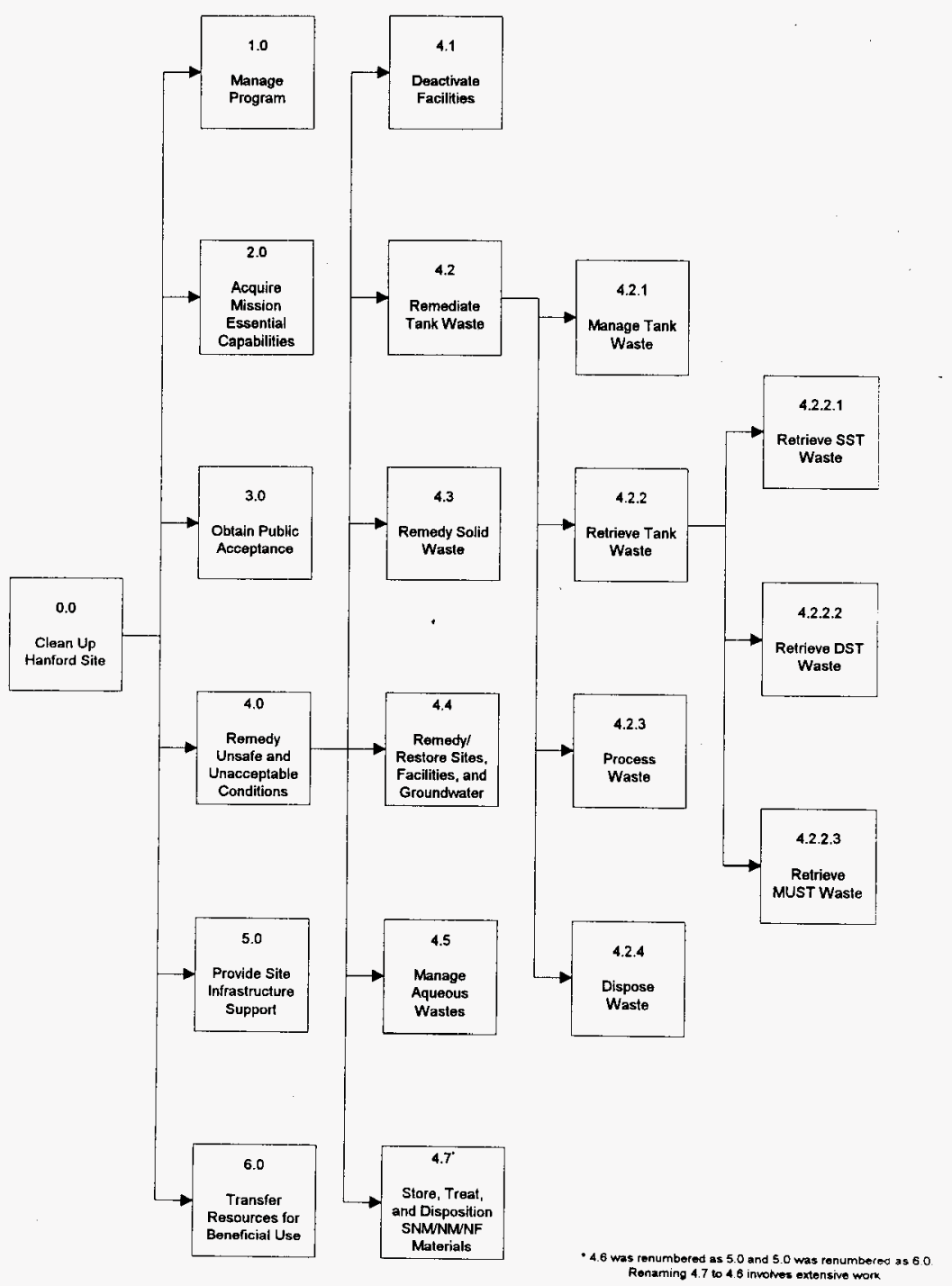

Figure 2-1. TWRS Function Hierarchy. 


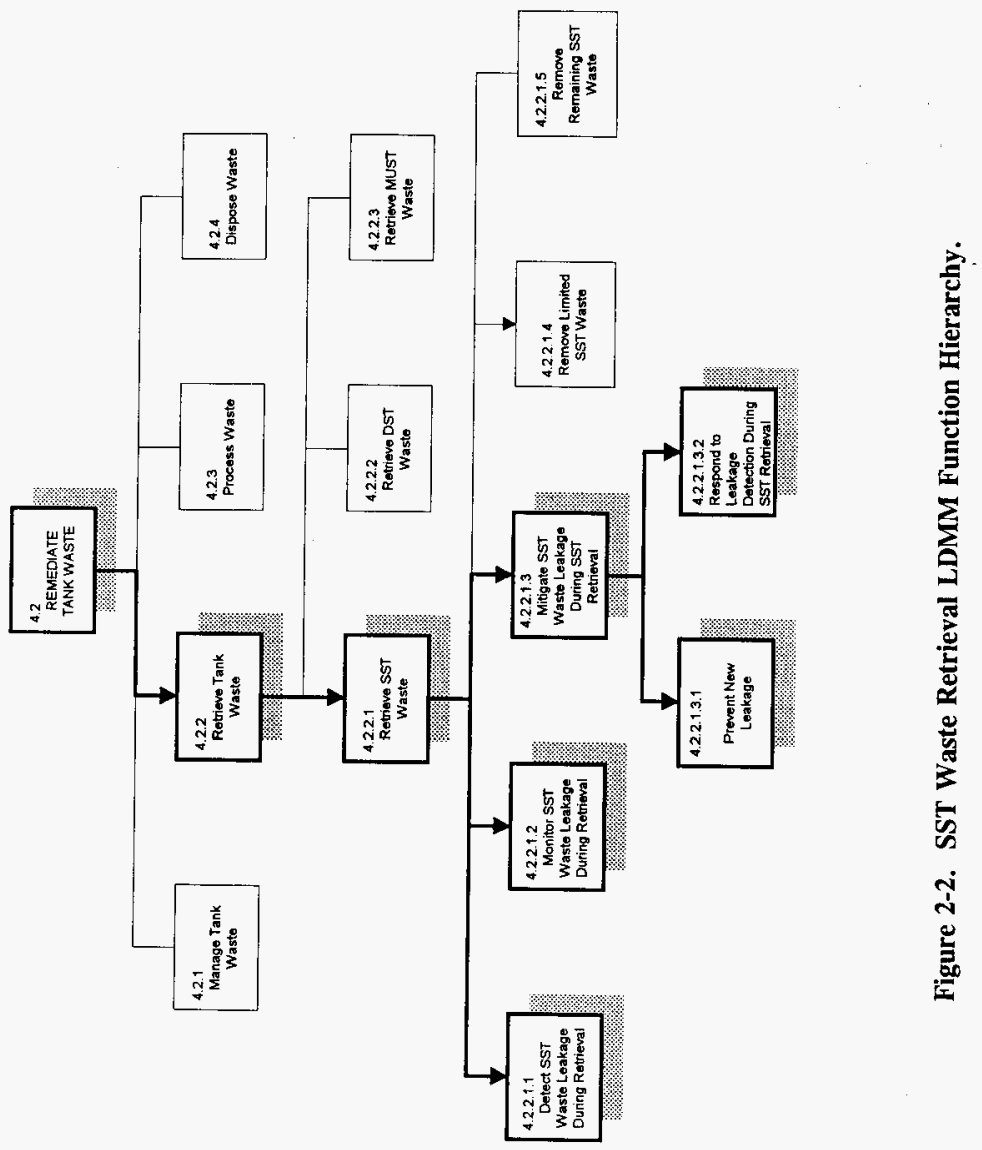


Table 2-1. SST Leakage Detection and Monitoring Requirements Allocation.

\begin{tabular}{|c|c|c|c|}
\hline Requirement & Subject & Function & Interface \\
\hline 40 CFR 302.6 & Notification Requirements & $\begin{array}{l}4.2 .2 .1 .1 \\
4.2 .2 .1 .2 \\
4.2 .2 .1 .3 \\
\end{array}$ & TBD \\
\hline 40 CFR 141.15 and 141.16 & Maximum Contaminant Levels & 4.2.2.1.3 & TBD \\
\hline DOE 5400.1, Chapter IV, 5b & Environmental Surveillance & $\begin{array}{l}4.2 .2 .1 .2 \\
4.2 .2 .1 .3\end{array}$ & TBD \\
\hline DOE 5400.5, Chapter II, 1d(3) & Impacts on Other Systems & 4.2.2.1.3 & TBD \\
\hline DOE 5400.5, Chapter II, 3c(2) & Discharge of Other Liquids & $\begin{array}{l}4.2 .2 .1 .1 \\
4.2 .2 .1 .2 \\
4.2 .2 .1 .3 \\
\end{array}$ & TBD \\
\hline DOE 5820.2A, Chapter I, 3c(3)(a) & Monitoring and Surveillance & \begin{tabular}{|l|}
4.2 .2 .1 .2 \\
4.2 .2 .1 .3 \\
\end{tabular} & TBD \\
\hline DOE 5820.2A, Chapter I, 3c(3)(b) & Integrity Assessment & $\begin{array}{l}4.2 .2 .1 .1 \\
4.2 .2 .1 .3 \\
\end{array}$ & TBD \\
\hline DOE 5820.2A, Chapter I, 3c(3)(c) & Emergency Power & 4.2 .2 .1 .3 & TBD \\
\hline DOE 5820.2A, Chapter I, 3c(3)(d) & Monitoring Wells & $\begin{array}{l}4.2 .2 .1 .2 \\
4.2 .2 .1 .3 \\
\end{array}$ & TBD \\
\hline DOE 5820.2A, Chapter I, 3c(4)(a) & Contingency Plan & 4.2 .2 .1 .3 & TBD \\
\hline DOE 5820.2A, Chapter I, 3c(4)(b) & Leakage Mitigation & 4.2.2.1.3 & TBD \\
\hline DOE 5820.2A, Chapter I, 3c(4)(c) & Emergency Equipment & 4.2.2.1.3 & TBD \\
\hline DOE 5820.2A, Chapter III, 3k & Environmental Monitoring & \begin{tabular}{|l|}
4.2 .2 .1 .2 \\
4.2 .2 .1 .3
\end{tabular} & TBD \\
\hline WAC $173-160-020$ & $\begin{array}{l}\text { Minimum Standards for Construction } \\
\text { and Maintenance of Wells - General }\end{array}$ & \begin{tabular}{|l|}
4.2 .2 .1 .2 \\
4.2 .2 .1 .3 \\
\end{tabular} & TBD \\
\hline WAC $173-303-640(4)(e)(i)$ & External Liner Systems & 4.2.2.1.3 & TBD \\
\hline WAC $173-303-640(4)(\mathrm{g})$ & Variance & 4.2 .2 .1 .3 & TBD \\
\hline WAC 173-303-640(6)(a) and (b) & Inspections & $\begin{array}{l}4.2 .2 .1 .1 \\
4.2 .2 .1 .2 \\
4.2 .2 .1 .3\end{array}$ & TBD \\
\hline WAC $173 \cdot 303-640(7)(c)(i)$ & $\begin{array}{l}\text { Migration of Leaks for Tank Systems in } \\
\text { Interim Status }\end{array}$ & 4.2 .2 .1 .3 & TBD \\
\hline WAC $173-303-640(7)(d)$ & Notifications, Reports & \begin{tabular}{|l|}
4.2 .2 .1 .1 \\
4.2 .2 .1 .3 \\
\end{tabular} & TBD \\
\hline WHC-IP-0842, Section $\overline{4.6 .2}$ & $\begin{array}{l}\text { Occurrence Reporting and Processing of } \\
\text { Operations Information }\end{array}$ & $\begin{array}{l}4.2 .2 .1 .1 \\
4.2 .2 .1 .2\end{array}$ & TBD \\
\hline
\end{tabular}

CFR - Code of Federal Regulations

TBD - to be determined

DOE - U.S. Department of Energy Order

WAC - Washington Administrative Code

SST - single-shell tank 


\section{FUNCTION ID NUMBER: 4.2 .2 .1 .1}

I. FUNCTION TITLE: Detect SST Waste Leakage During Retrieval

III. FUNCTION DEFINITION:

Detect and confirm leakage of waste from SSTs and ancillary components during retrieval of SST waste.

Detect leakage in the near-field zone by acquiring and evaluating the following data:

- $\quad$ Potential leakage conditions within the SST structure

- Waste inventory in the retrieval system

- Detect changes in the size and location of new and existing contaminant plumes.

Leakage detection during SST retrieval will be conducted as required to support the other functions and associated regulatory requirements until all of the SSTs have been retrieved.

IV. ENABLING ASSUMPTIONS:

No enabling assumptions were identified.

\section{INTERFACES}

A. Inputs

\subsection{I1 Raw Materials for SST Waste Leakage Detection During Retrieval}

From: External

Any material or services (e.g., steam, water, air, process chemicals, or electricity) needed from outside TWRS for leak detection during the retrieval of SST waste.

\subsection{Retrieval Operations Information for Leak Detection}

From: 4.2.2.1

Retrieval operations information consisting of general monitoring and surveillance data that includes waste level measurements, information related to the structure of the tank, and its safety status. 


\subsection{I3 SST Integrity Data}

From: 4.2.1.1.4

Information about the structural integrity of the SSTs prior to the start of retrieval. This information includes maximum and minimum allowable loads, waste temperatures, and leak potential estimates.

\subsection{I4 SST Waste Leakage Monitoring Information to SST Waste Leakage Detection}

From: 4.2 .2 .1 .2

SST waste retrieval leakage monitoring information, consisting of plans, data, and other information gathered by the SST Leakage Monitoring function and . provided to other functions. The information may be in paper or electronic form.

\subsection{I5 SST Waste Leakage Mitigation Information to SST Waste Leakage Detection}

From: 4.2 .2 .1 .3

SST waste retrieval leakage mitigation information, consisting of plans and other information gathered by the SST Leakage Mitigation function and provided to other functions. The information may be in paper or electronic form.

\section{B. Outputs}

\subsection{O1 SST Retrieval Radioactive Solid Waste}

Radioactive and radioactive dangerous solid waste generated from the Retrieve SST Waste function that has been segregated, packaged, assayed, and certified for transfer to Hanford Site Function 4.3, Remedy Solid Waste, for management and disposal.

\subsection{O2 SST Waste Leakage Detection Information to SST Waste Leakage Monitoring}

To: 4.2 .2 .1 .2

SST waste retrieval leakage detection information, consisting of data and other information gathered by the SST Leakage Detection function and provided to other functions. The information may be in paper or electronic form.

\subsection{O3 SST Waste Leakage Detection Information to SST Waste Leakage Mitigation}

To: 4.2 .2 .1 .3 
SST waste retrieval leakage detection information, consisting of data and other information gathered by the SST Leakage Detection function and provided to other functions. The information may be in paper or electronic form.

\section{FUNCTION REQUIREMENTS}

\section{A. Performance Requirements}

4.2.2.1.1 P1 Time Leakage Detection Frame The leakage detection system shall be capable of detecting the failure of either the primary containment structure (indirectly implied by indications of liquid movement out of the structure) or the presence of any hazardous waste or accumulated liquid (in the soil region/environment immediately exterior to the structure) within a time frame that allows for operational response, regardless of leak location. The time frame during which leakage detection must be accomplished will be "tank specific," and will include consideration of such factors as type of waste, amount, indications of degree of hazard to the environment, and retrieval operations schedule (overall sluicing time). Estimates for time required to sluice range from a few days to several months.

[WHC-SD-WM-ES-379, Section 5]

4.2.2.1.1 P2 Leakage Detection Reliability The leak detection system shall be capable of detecting the leak rate with an acceptable probability of detection and a minimal probability of false alarm, regardless of leak location. Parameters for "acceptability" and "minimal probability" will be tank specific, and will include consideration of such factors as type of waste, amount, and indications of degree of hazard to the environment.

[WHC-SD-WM-ES-379, Section 5]

4.2.2.1.1 P3 In-Tank Leakage Detection Deployment Deployment of the system shall not interfere with normal, ongoing, or planned functions or operations within the target tank. If deployed in-tank, the leakage detection system shall be capable of deployment remotely through access ports (risers) in the top of the SSTs. The existing risers are pipes of 4 to 12 in. in diameter, extending from the ground surface into the tank head space. Additional risers can be installed, pursuant to the structural limitations of the tank.

[WHC-SD-WM-ES-379, Section 5]

4.2.2.1.1 P4 External Leakage Detection Deployment If system deployment is external to the tank, the leakage detection system shall be capable of deployment in the soils surrounding the SSTs. Deployment shall not breach or impact the tank or any underground piping. Deployment of the system shall not interfere with normal, ongoing, or planned functions or operations external to the target tank.

[WHC-SD-WM-ES-379, Section 5] 
4.2.2.1.1 P5 In-Tank Leakage Detection Operation If deployed in the tank, the leakage detection system must be capable of surviving/functioning under current and planned in-tank physical conditions. Operation of the system shall not interfere with normal, ongoing, or planned functions or operations within the target tank. The leakage detection system shall be capable of withstanding the physical and radiological conditions (including temperatures ranging from $60^{\circ} \mathrm{F}$ to $200^{\circ} \mathrm{F}$, and various chemical compositions with high corrosivity) within the SSTs. Equipment placed within the tank shall be retractable to the top of the tank or be able to withstand the impact of water from a high-pressure sluicing nozzle. Equipment and instrumentation placed within the tank shall withstand exposure of penetrating radiation without significant degradation of performance in the time frame of sluicing.

[WHC-SD-WM-ES-379, Section 5]

4.2.2.1.1 P6 External Leakage Detection Operation If deployed external to the tank, the leakage detection system shall be capable of withstanding the physical and radiological conditions of the subsurface environment. Equipment and instruments placed in the soils surrounding the SSTs shall remain functional without significant degradation during the time frame of sluicing. Operation of the system shall not interfere with normal, ongoing, or planned functions or operations within the target tank.

[WHC-SD-WM-ES-379, Section 5]

4.2.2.1.1 P7 Impact of Leakage Detection Technology on Other TWRS Functions Relative to the TWRS baseline, any enhancements or alternatives proposed for SST leakage detection will be required to be supportive of and not impede SST waste tank safety, tank farm safety, storage, retrieval, and closure readiness activities.

[WHC-SD-WM-ES-379, Section 5]

\subsection{P8 Worker Safety/ALARA for Leakage Detection Technology General} requirements for worker safety requirements applicable to tank farm operations are included in Appendix A. The TWRS program is committed to continuing improvement in worker safety performance. Accordingly, worker safety will be a key consideration in evaluating proposed enhancements or alternatives to the baseline SST Retrieval LDMM systems.

[WHC-EP-0750, 11.9.10]

[DOE 6430.1A, Section 1300-1.3]

\section{B. Constraints}

\subsection{C1 Occurrence Reporting and Processing of Operations Information} Notification and reporting will be performed on indications that specification limits have been exceeded via Westinghouse Hanford Company (WHC) Occurrence Notification procedures.

[WHC-1P-0842, Section 4.6.2] 
4.2.2.1.1 C2 Notification Requirements (a) Any person in charge of a vessel or an offshore or an onshore facility shall, as soon as he has knowledge of any release (other than a federally permitted release or application of a pesticide) of a hazardous substance from such vessel or facility in a quantity equal to or exceeding the reportable quantity determined by this part in any 24-hour period, immediately notify the National Response Center ((800) 424-8802; in Washington D.C. (202) 4262675).

[40 CFR 302.6]

4.2.2.1.1 C3 Discharge of Other Liquids Liquid discharges, even though uncontaminated, are prohibited in inactive release areas to prevent the further spread of radionuclides previously deposited.

[DOE 5400.5, Chapter II, 3c(2)]

4.2.2.1.1 C4 Integrity Assessment (b) A method for periodically assessing waste storage tank integrity (e.g., coupons, photographic inspections, leak detectors, liquid level devices) shall be established and documented.

[DOE 5820.2A, Chapter I, 3c(3)(b)]

4.2.2.1.1 C5 Inspections (a) The owner or operator must develop and follow a schedule and procedure for inspecting overfill controls. (b) The owner or operator must inspect at least once each operating day: (i) Aboveground portions of the tank system, if any, to detect corrosion or releases of waste; (ii) Data gathered from monitoring any leak detection equipment (e.g., pressure or temperature gauges, monitoring wells) to ensure that the tank system is being operated according to its design; and (iii) The construction materials and the area immediately surrounding the externally accessible portion of the tank system, including the secondary containment system (e.g., dikes) to detect erosion or signs of releases of dangerous waste (e.g., wet spots, dead vegetation).

$[W A C$ 173-303-640(6)(a) and (b)]

4.2.2.1.1 C6 Notifications, Reports (i) Any release to the environment, except as provided in (d)(ii) of this subsection, must be reported to the department within twenty-four hours of its detection. Any release above the "reportable quantity" must also be reported to the National Response Center pursuant to 40 CFR Part 302. (ii) A leak or spill of dangerous waste is exempted from the requirements of (d) of this subsection if it is: (A) Less than or equal to a quantity of one pound, or the "Reportable Quantity" (RQ) established in 40 CFR Part 302, whichever is less; and (B) Immediately contained and cleaned-up. (iii) Within thirty days of detection a release to the environment, a report containing the following information must be submitted to the department: (A) Likely route of migration of the release; (B) Characteristics of the surrounding soil (soil composition, geology, hydrogeology, climate); (C) Results of any monitoring or sampling conducted in connection with the release (if available). If sampling or monitoring data relating to the release are not available within thirty days, these data must be submitted to the department as soon as 
they become available; (D) Proximity to downgradient drinking water, surface water, and populated areas; and (E) Description of response actions taken or planned.

[WAC 173-303-640(7)(d)] 


\section{FUNCTION ID NUMBER: 4.2 .2 .1 .2}

II. FUNCTION TITLE: Monitor SST Waste Leakage During Retrieval

\section{FUNCTION DEFINITION:}

The waste leakage from retrieval of SST waste is monitored to obtain data that will be used to determine waste plume volume, location, and plume migration direction.

Monitoring includes obtaining, transmitting, receiving, recording, and displaying the leakage data.

\section{ENABLING ASSUMPTIONS:}

No enabling assumptions were identified.

\section{INTERFACES}

A. Inputs

\subsection{I1 Raw Materials for SST Waste Leakage Monitoring During Retrieval} From: External

Any material or services (e.g., steam, water, air, process chemicals, or electricity) needed from outside TWRS for leak monitoring during the retrieval of SST waste.

\subsection{Retrieval Operations Information for Leak Monitoring}

From: 4.2.2.1

Retrieval operations information consisting of general tank monitoring and surveillance data that includes waste level measurements, information related to the structure of the tank, and its safety status.

\subsection{I3 Tank Farm Geological Data}

From: External

Information about the tank farm geology, including soil properties, lithology, history, and hydrology.

\subsection{I4 SST Waste Leakage Detection Information to SST Waste Leakage Monitoring}

From: 4.2 .2 .1 .1

SST waste retrieval leakage detection information, consisting of plans, data, and other information gathered by the SST Leakage Detection function and provided to other functions. The information may be in paper or electronic form. 


\subsection{I5 SST Waste Leakage Mitigation Information to SST Waste Leakage Monitoring}

From: 4.2.2.1.3

SST waste retrieval leakage mitigation information, consisting of plans, data, and other information gathered by the SST Leakage Mitigation function and provided to other functions. The information may be in paper or electronic form.

B. Outputs

\subsection{O1 SST Retrieval Radioactive Solid Waste}

To: 4.3

Radioactive and radioactive dangerous solid waste generated from the Retrieve SST Waste function that has been segregated, packaged, assayed, and certified for transfer to Hanford Site Function 4.3 Remedy Solid Waste, for management and disposal.

\subsection{O2 SST Waste Leakage Monitoring Information to SST Waste Leakage Detection}

To: 4.2 .2 .1 .1

SST waste retrieval leakage monitoring information, consisting of plans, data, and other information gathered by the SST Leakage Monitoring function and provided to other functions. The information may be in paper or electronic form.

\subsection{O3 SST Waste Leakage Monitoring Information to SST Waste Leakage Mitigation}

To: 4.2 .2 .1 .3

SST waste retrieval leakage monitoring information, consisting of plans, data, and other information gathered by the SST Leakage Monitoring function and provided to other functions. The information may be in paper or electronic form.

\section{FUNCTION REQUIREMENTS}

\section{A. Performance Requirements}

4.2.2.1.2 P1 Leakage Monitoring The leakage monitoring system shall be capable of providing surveillance data to identify the location and migration direction of leakage plumes. The system shall be capable of providing this information by interrogation of the entire soil mass of interest, surrounding the target tank. [WHC-SD-WM-ES-379, Section 5]

4.2.2.1.2 P2 Leakage Monitoring Reliability The leakage monitoring system shall be capable of providing surveillance data to identify the location and migration 
direction of leakage plumes with an acceptable probability of accuracy and a minimal probability of false data. Parameters for "acceptability" and "minimal probability" will be tank specific, and will include consideration of such factors as type of waste, amount, and indications of degree of hazard to the environment.

[WHC-SD-WM-ES-379, Section 5]

4.2.2.1.2 P3 Leakage Monitoring Deployment The leakage monitoring system shall be capable of deployment in the soils surrounding the SSTs. Deployment shall not breach or impact the tank or any underground piping. Deployment of the system shall not interfere with normal, ongoing, or planned functions or operations external/outside of the target tank.

[WHC-SD-WM-ES-379, Section 5]

4.2.2.1.2 P4 Leakage Monitoring Operation The leakage monitoring system shall be capable of withstanding the physical and radiological conditions of the subsurface environment. Equipment and instruments placed in the soils surrounding the SSTs shall remain functional without significant degradation during the time frame of sluicing. Operation of the system shall not interfere with normal, ongoing, or planed functions or operations within the target tank.

[WHC-SD-WM-ES-379, Section 5]

\subsection{P5 Impact of Leakage Monitoring Technology on Other TWRS}

Functions Relative to the TWRS baseline, any enhancements or alternatives proposed for SST leakage monitoring will be required to be supportive of and not impede SST waste tank safety, storage, retrieval, and closure readiness activities.

[WHC-SD-WM-ES-379, Section 5]

\subsection{P6 Worker Safety/ALARA for Leakage Monitoring Technology}

General requirements for worker safety requirements applicable to tank farm

operations are included in Appendix A. The TWRS program is committed to continuing improvement in worker safety performance. Accordingly, worker safety will be a key consideration in evaluating proposed enhancements or alternatives to the baseline SST leakage detection and monitoring systems.

[WHC-EP-0750, 11.9.10]

[DOE 6430.1A, Section 1300-1.3]

\section{B. Constraints}

\subsection{C1 Occurrence Reporting and Processing of Operations Information} Notification and reporting are performed upon indications that specification limits have been exceeded via WHC Occurrence Notification procedures.

[WHC-IP-0842, Section 4.6.2]

4.2.2.1.2 C2 Notification Requirements (a) Any person in charge of a vessel or an offshore or an onshore facility shall, as soon as he has knowledge of any release 
(other than a federally permitted release or application of a pesticide) of a hazardous substance from such vessel or facility in a quantity equal to or exceeding the reportable quantity determined by this part in any 24-hour period, immediately notify the National Response Center ((800) 424-8802; in Washington D.C. (202) 4262675).

[40 CFR 302.6]

4.2.2.1.2 C3 Environmental Surveillance (1) Environmental surveillance shall be conducted to monitor the effects, if any, of DOE activities on onsite and offsite environmental and natural resources. An environmental surveillance screening program shall be undertaken at DOE sites to determine the need for a permanent surveillance program. Environmental surveillance shall be designed to satisfy one or more of the following program objectives: (a) Verify compliance with applicable environmental laws and regulations; (b) Verify compliance with environmental commitments made in Environmental Impact Statements, Environmental Assessments, Safety Analysis Reports, or other official DOE documents; (c) Characterize and define trends in the physical, chemical and biological condition of environmental media; (d) Establish baselines of environmental quality; (e) Provide a continuing assessment of pollution abatement programs; (f) Identify and quantify new or existing environmental quality problems. (2) Environmental surveillance programs and components should be determined on a site-specific basis by the field organization. Programs should reflect facility characteristics, applicable regulations, hazard potential, quantities and concentrations of materials released, the extent and use of affected air, land, and water, and specific local public interest or concern.

Surveillance programs are likely to include one or more of the following: (a) Monitoring stations; (b) Sampling and analysis; and (c) Monitoring data recordkeeping.

[DOE 5400.1, Chapter IV, 5b]

4.2.2.1.2 C4 Discharge of Other Liquids Liquid discharges, even though uncontaminated, are prohibited in inactive release areas to prevent the further spread of radionuclides previously deposited.

[DOE 5400.5, Chapter II, 3c(2)]

4.2.2.1.2 C5 Monitoring and Surveillance Monitoring and surveillance capability shall exist to provide liquid volume, waste inventory data, and identification of failed containment.

[DOE 5820.2A, Chapter I, 3c(3)(a)]

4.2.2.1.2 C6 Monitoring Wells A system of ground water or vadose zone monitoring wells meeting the Resource Conservation and Recovery Act requirements per 40 CFR 264 shall be installed, as a minimum, around clusters of liquid waste storage tanks.

[DOE 5820.2A, Chapter I, 3c(3)(d)] 
4.2.2.1.2 C7 Environmental Monitoring (1) Each operational or non-operational low-level waste treatment, storage, and disposal facility shall be monitored by an environmental monitoring program that conforms with DOE 5484.1 and, at a minimum, meet the requirements of paragraph $3 K(2)$ through $3 K(4)$. (2) The environmental monitoring program shall be designed to measure: (a) operational effluent releases; (b) migration of radionuclides; (c) disposal unit subsidence; and (d) changes in disposal facility and disposal site parameters which may affect long-term site performance. (3) Based on the characteristics of the facility being monitored, the environmental monitoring program may include, but not necessarily be limited to, monitoring surface soil, air, surface water, and, in the subsurface, soil and water, both in the saturated and the unsaturated zones. (4) The monitoring program shall be capable of detecting changing trends in performance sufficiently in advance to allow application of any necessary corrective action prior to exceeding performance objectives. The monitoring program shall be able to ascertain whether or not effluents from each treatment, storage, or disposal facility or disposal site meet the requirements of applicable EH Orders.

[DOE 5820.2A, Chapter III, 3k]

\subsection{C8 Minimum Standards for Construction and Maintenance of Wells -} General The following minimum standards shall apply to all wells constructed in the state of Washington. It is the responsibility of the water well contractor and the property owner to take whatever measures are necessary to guard against waste and contamination of the ground water resources.

[WAC 173-160-020]

4.2.2.1.2 C9 Inspections (a) The owner or operator must develop and follow a schedule and procedure for inspecting overfill controls. (b) The owner or operator must inspect at least once each operating day: (i) Aboveground portions of the tank system, if any, to detect corrosion or releases of waste; (ii) Data gathered from monitoring any leak detection equipment (e.g., pressure or temperature gauges, monitoring wells) to ensure that the tank system is being operated according to its design; and (iii) The construction materials and the area immediately surrounding the externally accessible portion of the tank system, including the secondary containment system (e.g., dikes) to detect erosion or signs of releases of dangerous waste (e.g., wet spots, dead vegetation).

[WAC 173-303-640(6)(a) and (b)] 
WHC-SD-WM-FRD-021 REV. 1

This page intentionally left blank. 


\section{FUNCTION ID NUMBER: 4.2.2.1.3}

II. FUNCTION TITLE: Mitigate SST Waste Leakage During SST Waste Retrieval

III. FUNCTION DEFINITION:

Leakage mitigation includes any and all actions that might be undertaken, at any time prior to, during, or after sluicing, to eliminate the possibility of leakage or to reduce leakage if it should occur.

\section{ENABLING ASSUMPTIONS:}

No enabling assumptions were identified.

\section{INTERFACES}

A. Inputs

\subsection{I1 SST Leak Monitoring Information}

From: 4.2.2.1.2

General tank monitoring information consists of plans, data, and other information gathered by the SST Leakage Monitoring functions and provided to other functions. The information may be in paper or electronic form.

\subsection{I2 SST Integrity Data}

From: 4.2.1.1.4

Information about the structural integrity of the SSTs prior to the start of the retrieval. This information includes maximum and minimum allowable loads, waste temperatures, and leak potential estimates.

\subsection{I3 Tank Farm Geological Data}

From: External

Information about the tank farm geology, including soil properties, lithology, history, and hydrology.

\subsection{I4 Raw Materials for SST Waste Leakage Mitigation During Retrieval From: External}

Any material or services (e.g., steam, water, air, process chemicals, electricity) needed from outside TWRS for the mitigation of leakage during the retrieval of SST waste. 


\subsection{I5 Historical SST Leakage Information}

From: External

Historical information about past SST leakage and soil contamination plumes. This information consists of migration paths, leakage volumes, leakage depths, etc.

\subsection{I6 SST Waste Leakage Detection Information to SST Waste Leakage Mitigation}

From: 4.2.2.1.1

SST waste retrieval leakage detection information, consisting of plans, data, and other information gathered by the SST Leakage Detection function and provided to other functions. The information may be in paper or electronic form.

\subsection{I7 SST Waste Leakage Monitoring Information to SST Waste Leakage Mitigation}

From: 4.2.2.1.2

SST waste retrieval leakage monitoring information, consisting of plans, data, and other information gathered by the SST Leakage Monitoring function and provided to other functions. The information may be in paper or electronic form.

\section{B. Outputs}

\subsection{O1 SST Retrieval Radioactive Solid Waste}

To: 4.3

Radioactive and radioactive dangerous solid waste generated from the Retrieve SST Waste function that has been segregated, packaged, assayed, and certified for transfer to Hanford Site Function 4.3, Remedy Solid Waste, for management and disposal.

\subsection{O2 SST Waste Leakage Mitigation Information to SST Waste Leakage Detection}

To: 4.2.2.1.1

SST waste retrieval leakage mitigation information, consisting of plans, data, and other information gathered by the SST Leakage Mitigation function and provided to other functions. The information may be in paper or electronic form. 


\subsection{O3 SST Waste Leakage Mitigation Information to SST Waste Leakage Monitoring}

To: 4.2 .2 .1 .2

SST waste retrieval leakage mitigation information, consisting of plans, data, and other information gathered by the SST Leakage Mitigation function and provided to other functions. The information may be in paper or electronic form.

\section{FUNCTION REQUIREMENTS}

\section{A. Performance Requirements}

4.2.2.1.3 P1 In-Tank Leakage Mitigation Deployment If deployed in-tank, the leakage mitigation system or operational response shall be capable of deployment remotely through access ports (risers) in the top of the SSTs. The existing risers are pipes of 4 to 12 in. in diameter, extending from the ground surface into the tank head space. Additional risers can be installed, pursuant to the structural limitations of the tank.

[WHC-SD-WM-ES-379, Section 5]

4.2.2.1.3 P2 External Leakage Mitigation Deployment If system deployment is external to the tank, the leakage mitigation system or operational response shall be capable of deployment in the soils surrounding the SSTs. Deployment shall not breach or impact the tank or any underground piping.

[WHC-SD-WM-ES-379, Section 5]

4.2.2.1.3 P3 In-Tank Leakage Mitigation Operation If deployed in the tank, the leakage mitigation system or operational response shall be capable of withstanding the physical and radiological conditions of the SSTs. Equipment and instrumentation placed within the tank shall withstand exposure of penetrating radiation at an exposure rate without significant degradation of performance.

[WHC-SD-WM-ES-379, Section 5]

4.2.2.1.3 P4 External Leakage Mitigation Operation If deployed external to the tank, the leakage mitigation system or operational response shall be capable of withstanding the physical and radiological conditions of the subsurface environment. Equipment and instruments placed in the soils surrounding the SSTs shall remain functional without significant degradation.

[WHC-SD-WM-ES-379, Section 5]

4.2.2.1.3 P5 Impact of Leakage Mitigation on Other TWRS Functions Relative to the TWRS baseline, any enhancements or alternatives proposed for SST leakage mitigation will be required to be supportive of and not impede SST waste tank safety, storage, retrieval, and closure readiness activities.

[WHC-SD-WM-ES-379, Section 5] 
4.2.2.1.3 P6 Worker Safety/ALARA for Leakage Mitigation General requirements for worker safety requirements applicable to tank farm operations are included in Appendix A. The TWRS program is committed to continuing improvement in worker safety performance. Accordingly, worker safety will be a key consideration in evaluating proposed enhancements or alternatives to the baseline SST leakage detection and monitoring systems.

[WHC-EP-0750, 11.9.10]

[DOE 6430.1A, Section 1300-1.3]

\section{B. Constraints}

4.2.2.1.3 C1 Impacts on Downstream Water Systems The liquid effluents from DOE activities shall not cause private or public drinking water systems downstream of the facility discharge to exceed the drinking water radiological limits of 40 CFR 141 .

[DOE 5400.5, Chapter II, Id(3)]

\subsection{C2 Maximum Contaminant Levels \$141.15 Maximum contaminant} levels for radium-226, radium-228, and gross alpha particle radioactivity in community water systems. The following are the maximum contaminant levels for radium-226, radium-228, and gross alpha particle radioactivity: (a) Combined radium-226 and radium-228 - $5 \mathrm{pCi} / \mathrm{L}$. (b) Gross alpha particle activity (including radium- 226 but excluding radon and uranium) $-15 \mathrm{pCi} / \mathrm{L}$.

$\$ 141.16$ Maximum contaminant levels for beta particle and photon radioactivity from man-made radionuclides in community water systems. (a) The average annual concentration of beta particle and photon radioactivity from man-made radionuclides in drinking water shall not produce an annual dose equivalent to the total body or any internal organ greater than $4 \mathrm{mrem} /$ year.

[40 CFR 141.15 and 141.16(a)]

\subsection{C3 Migration of Leaks for Tank Systems in Interim Status (i) Prevent further migration of the leak or spill to soils or surface water.}

[WAC 173-303-640(7)(c)(i)]

4.2.2.1.3 C4 Environmental Surveillance (1) Environmental surveillance shall be conducted to monitor the effects, if any, of DOE activities on onsite and offsite environmental and natural resources. An environmental surveillance screening program shall be undertaken at DOE sites to determine the need for a permanent surveillance program. Environmental surveillance shall be designed to satisfy one or more of the following program objectives: (a) Verify compliance with applicable environmental laws and regulations; (b) Verify compliance with environmental commitments made in Environmental Impact Statements, Environmental Assessments, Safety Analysis Reports, or other official DOE documents; (c) Characterize and define trends in the physical, chemical and biological condition of environmental media; (d) Establish baselines of environmental quality; (e) Provide a continuing 
assessment of pollution abatement programs;(f) Identify and quantify new or existing environmental quality problems. (2) Environmental surveillance programs and components should be determined on a site-specific basis by the field organization. Programs should reflect facility characteristics, applicable regulations, hazard potential, quantities and concentrations of materials released, the extent and use of affected air, land, and water, and specific local public interest or concern. Surveillance programs are likely to include one or more of the following: (a) Monitoring stations; (b) Sampling and analysis; and (c) Monitoring data recordkeeping.

[DOE 5400.1, Chapter IV, 5b]

4.2.2.1.3 C5 Discharge of Other Liquids Liquid discharges, even though uncontaminated, are prohibited in inactive release areas to prevent the further spread of radionuclides previously deposited.

[DOE 5400.5, Chapter II, 3c(2)]

4.2.2.1.3 C6 Monitoring and Surveillance Monitoring and surveillance capability shall exist to provide liquid volume, waste inventory data, and identification of failed containment.

[DOE 5820.2A, Chapter I, 3c(3)(a)]

4.2.2.1.3 C7 Integrity Assessment A method for periodically assessing waste storage tank integrity (e.g., coupons, photographic inspections, leak detectors, liquid level devices) shall be established and documented.

[DOE 5820.2A, Chapter $1,3 c(3)(b)]$

4.2.2.1.3 C8 Emergency Power Electrical monitoring and leak detection devices essential to safe operations shall be provided with backup power, as appropriate, to ensure operability under emergency conditions.

[DOE 5820.2A, Chapter I, 3c(3)(c)]

4.2.2.1.3 C9 Monitoring Wells A system of ground water or vadose zone monitoring wells meeting the Resource Conservation and Recovery Act requirements per 40 CFR 264 shall be installed, as a minimum, around clusters of liquid waste storage tanks.

[DOE 5820.2A, Chapter I, 3c(3)(d)]

4.2.2.1.3 C10 Contingency Plan A contingency action plan shall be maintained to respond to spills or leaks and other credible emergencies as identified in the Safety Analysis Reports.

[DOE 5820.2A, Chapter I, 3c(4)(a)] 
4.2.2.1.3 C11 Leakage Mitigation Upon detection of released radioactive materials, steps shall be taken to prevent further migration of the release to soil or surface water. Major contamination in the soil shall be removed or stabilized unless compliance with this requirement would cause greater harm to human health or the environment.

[DOE 5820.2A, Chapter I, 3c(4)(b)]

4.2.2.1.3 C12 Emergency Equipment For emergency situations involving pumpable liquid in singly contained tanks, appropriate equipment (e.g., pumps) shall be maintained to provide removal of liquid.

[DOE 5820.2A, Chapter I, 3c(4)(c)]

4.2.2.1.3 C13 Environmental Monitoring (1) Each operational or non-operationallow-level waste treatment, storage, and disposal facility shall be monitored by an environmental monitoring program that conforms with DOE 5484.1 and, at a minimum, meet the requirements of paragraph $3 K(2)$ through $3 K(4)$. (2) The environmental monitoring program shall be designed to measure: (a) operational effluent releases; (b) migration of radionuclides; (c) disposal unit subsidence; and (d) changes in disposal facility and disposal site parameters which may affect long-term site performance. (3) Based on the characteristics of the facility being monitored, the environmental monitoring program may include, but not necessarily be limited to, monitoring surface soil, air, surface water, and, in the subsurface, soil and water, both in the saturated and the unsaturated zones. (4) The monitoring program shall be capable of detecting changing trends in performance sufficiently in advance to allow application of any necessary corrective action prior to exceeding performance objectives. The monitoring program shall be able to ascertain whether or not effluents from each treatment, storage, or disposal facility or disposal site meet the requirements of applicable EH Orders.

[DOE 5820.2A, Chapter III, 3k]

4.2.2.1.3 C14 Minimum Standards for Construction and Maintenance of Wells General The following minimum standards shall apply to all wells constructed in the state of Washington. It is the responsibility of the water well contractor and the property owner to take whatever measures are necessary to guard against waste and contamination of the ground water resources.

[WAC 173-160-020]

4.2.2.1.3 C15 External Liner Systems External liner systems must be: (A) Designed or operated to contain one hundred percent of the capacity of the largest tank within its boundary; (B) Designed or operated to prevent run-on or infiltration of precipitation into the secondary containment system unless the collection system has sufficient excess capacity to contain run-on or infiltration. Such additional capacity must be sufficient to contain precipitation from a twenty-five-year, twenty-four-hour rainfall event. (C) Free of cracks or gaps; and (D) Designed and installed to surround the tank completely and to cover all surrounding earth likely to come into 
contact with the waste if the waste is released from the tank(s) (i.e., capable of preventing lateral as well as vertical migration of the waste).

[WAC 173-303-640(4)(e)(i)]

4.2.2.1.3 C16 Variance The owner or operator may obtain a variance from the requirements of this subsection if the department finds, as a result of a demonstration by the owner or operator that alternative design and operating practices, together with location characteristics, will prevent the migration of any dangerous waste or dangerous constituents into the ground water, or surface water at least as effectively as secondary containment during the active life of the tank system or that in the event of a release that does migrate to ground water or surface water, no substantial present or potential hazard will be posed to human health or the environment. New underground tank systems may not, per a demonstration in accordance with (g)(ii) of this subsection, be exempted from the secondary containment requirements of this section. (i) In deciding whether to grant a variance based on a demonstration of equivalent protection of ground water and surface water, the department will consider: (A) The nature and quantity of the wastes; (B) The proposed alternate design and operation; (C) The hydrogeologic setting of the facility, including the thickness of soils present between the tank system and ground water; and (D) All other factors that would influence the quality and mobility of the dangerous constituents and the potential for them to migrate to ground water or surface water. (ii) In deciding whether to grant a variance based on a demonstration of no substantial present or potential hazard, the department will consider: (A) The potential adverse effects on ground water, surface water, and land quality taking into account: (I) The physical and chemical characteristics of the waste in the tank system, including its potential for migration; (II) The hydrogeological characteristics of the facility and surrounding land; (III) The potential for health risks caused by human exposure to waste constituents; (IV) The potential for damage to wildlife, crops, vegetation, and physical structures caused by exposure to waste constituents; and (V) The persistence and permanence of the potential adverse effects. (B) The potential adverse effects of a release on ground-water quality, taking into account: (I) The quantity and quality of ground water and the direction of ground-water flow; (II) The proximity and withdrawal rates of ground-water users; (III) The current and future uses of ground water in the area; and (IV) The existing quality of ground water, including other sources of contamination and their cumulative impact on the ground-water quality. (C) The potential adverse effects of a release on surface water quality, taking into account: (I) The quantity and quality of ground water and the direction of ground-water flow; (II) The patterns of rainfall in the region; (III) The proximity of the tank system to surface waters; (IV) The current and future uses of surface waters in the area and any water quality standards established for those surface waters; and (V) The existing quality of surface water, including other sources of contamination and the cumulative impact on surface-water quality. (D) The potential adverse effects of a release on the land surrounding the tank system, taking into account: (I) The patterns of rainfall in the region; and (II) The current and future uses of the surrounding land. (iii) The owner or operator of a tank system, for which a variance 
from secondary containment had been granted in accordance with the requirements of (g)(i) of this subsection, at which a release of dangerous waste has occurred from the primary tank system but has not migrated beyond the zone of engineering control (as established in the variance), must: (A) Comply with the requirements of subsection (7) of this section, except subsection (7)(d) of this section; and (B) Decontaminate or remove contaminated soil to the extent necessary to: (I) Enable the tank system for which the variance was granted to resume operation with the capability for the detection of releases at least equivalent to the capability it had prior to the release; and (II) Prevent the migration of dangerous waste or dangerous constituents to ground water or surface water. (C) If contaminated soil cannot be removed or decontaminated in accordance with (g)(iii)(B) of this subsection, comply with the requirements of subsection (8) of this section. (iv) The owner or operator of a tank system, for which a variance from secondary containment had been granted in accordance with the requirements of $(\mathrm{g})(\mathrm{i})$ of this subsection, at which a release of dangerous waste has occurred from the primary tank system and has migrated beyond the zone of engineering control (as established in the variance), must: (A) Comply with the requirements of subsection (7)(a), (b), (c), and (d) of this section; and (B) Prevent the migration of dangerous waste or dangerous constituents to ground water or surface water, if possible, and decontaminate or remove contaminated soil. If contaminated soil cannot be decontaminated or removed or if ground water has been contaminated, the owner or operator must comply with the requirements of subsection (8)(b) of this section; and (C) If repairing, replacing, or reinstalling the tank system, provide secondary containment in accordance with the requirements of (a) through (f) of this subsection or reapply for a variance from secondary containment and meet the requirements for new tank systems in subsection (3) of this section if the tank system is replaced. The owner or operator must comply with these requirements even if contaminated soil can be decontaminated or removed and ground water or surface water has not been contaminated.

[WAC 173-303-640(4)(g)]

4.2.2.1.3 C17 Inspections (a) The owner or operator must develop and follow a schedule and procedure for inspecting overfill controls. (b) The owner or operator must inspect at least once each operating day: (i) Aboveground portions of the tank system, if any, to detect corrosion or releases of waste; (ii) Data gathered from monitoring any leak detection equipment (e.g., pressure or temperature gauges, monitoring wells) to ensure that the tank system is being operated according to its design; and (iii) The construction materials and the area immediately surrounding the externally accessible portion of the tank system, including the secondary containment system (e.g., dikes) to detect erosion or signs of releases of dangerous waste (e.g., wet spots, dead vegetation).

[WAC 173-303-640(6)(a)]

4.2.2.1.3 C18 Notifications, Reports (i) Any release to the environment, except as provided in (d)(ii) of this subsection, must be reported to the department within twenty-four hours of its detection. Any release above the "reportable quantity" must 
also be reported to the National Response Center pursuant to 40 CFR Part 302. (ii) A leak or spill of dangerous waste is exempted from the requirements of (d) of this subsection if it is: (A) Less than or equal to a quantity of one pound, or the "Reportable Quantity" (RQ) established in 40 CFR Part 302, whichever is less; and (B) Immediately contained and cleaned-up. (iii) Within thirty days of detection of a release to the environment, a report containing the following information must be submitted to the department: (A) Likely route of migration of the release; (B) Characteristics of the surrounding soil (soil composition, geology, hydrogeology, climate); (C) Results of any monitoring or sampling conducted in connection with the release (if available). If sampling or monitoring data relating to the release are not available within thirty days, these data must be submitted to the department as soon as they become available; (D) Proximity to downgradient drinking water, surface water, and populated areas; and (E) Description of response actions taken or planned. 
WHC-SD-WM-FRD-021 REV. 1

This page intentionally left blank. 
I. FUNCTION ID NUMBER: 4.2.2.1.3.1

II. FUNCTION TITLE: SST Leakage Mitigation - Prevent New Leakage

III. FUNCTION DEFINITION:

Prevent new leakage during retrieval of limited SST waste through use of operational, procedural, and administrative methods.

IV. ENABLING ASSUMPTIONS:

No enabling assumptions were identified.

V. INTERFACES

A. Inputs

Same as 4.2.2.1.3

B. Outputs

Same as 4.2.2.1.3

VI. FUNCTION REQUIREMENTS

A. Performance Requirements

4.2.2.1.3.1 P1 Effectiveness The leakage mitigation system shall be capable of preventing or minimizing new waste leakage or the environmental impact of leakage.

[WHC-SD-WM-ES-379]

B. Constraints

Same as 4.2.2.1.3 
WHC-SD-WM-FRD-021 REV. 1

This page intentionally left blank. 


\section{FUNCTION ID NUMBER: 4.2.2.1.3.2}

II. FUNCTION TITLE: Respond to SST Waste Leakage During Retrieval

III. FUNCTION DEFINITION:

Respond to leak detection signal that includes the activation and/or shutdown of appropriate systems and initiating the appropriate actions to mitigate and minimize leakage of waste.

IV. ENABLING ASSUMPTIONS:

No enabling assumptions were identified.

\section{INTERFACES}

\section{A. Inputs}

\subsection{I1 Retrieval Operations Information for Responding to Leak Detection}

From: 4.2.2.1

Retrieval operations information consisting of general tank detection, monitoring and surveillance data that includes waste level measurements, information related to the structure of the tank, its safety status, and status of retrieval operations. This information will be used to minimize/mitigate leakage volumes.

\subsection{I2 SST Waste Leakage Detection Information to SST Waste Leakage Mitigation}

From: 4.2.2.1.1

Detection information consists of plans, data, and other information gathered by the SST Leakage Detection function and provided to other functions. The information may be in paper or electronic form.

\subsection{I3 SST Waste Leakage Monitoring Information to SST Waste Leakage Mitigation}

From: 4.2.2.1.1

Detection information consists of plans, data, and other information gathered by the SST Leakage Monitoring function and provided to other functions. The information may be in paper or electronic form. 


\section{B. Outputs}

\subsection{O1 Retrieval Operations Data}

To: 4.2 .2 .1

Retrieval operations data that contains information on leakage detection and location that impact safety and performance of the retrieval operations. This data may be used to determine the next sequence of events necessary to minimize/mitigate further leakage.

\subsection{O2 Secure/Shutdown System}

To: 4.2.2.1

Actions, whether automatic or operational, to secure/shutdown appropriate retrieval system element(s) as a result of a leakage detection.

\section{FUNCTION REQUIREMENTS}

\section{A. Performance Requirements}

4.2.2.1.3.2 P1 Time Frame The leakage operational response shall begin as soon as reasonably possible after a positive detection of a leak during retrieval.

\section{B. Constraints}

[WHC-SD-WM-ES-379]

Same as 4.2.2.1.3. 


\subsection{ARCHITECTURE}

Architecture represents a strategy, process, or piece of the actual physical system that satisfies a corresponding requirement. Architecture hierarchy is identical to, and derived from, the function hierarchy. The SST Retrieval LDMM function hierarchy is described in Section 2. This section describes the sixth and seventh SST Retrieval LDMM architecture levels. The sixth-level architecture establishes the general aspects of the SST Retrieval LDMM systems. The seventh-level architecture defines the baseline and alternate methods in greater detail.

The architecture descriptions were developed to facilitate better definition of potential system design concepts. As the concepts are further evaluated and decisions are made regarding implementation, the architecture descriptions will be revised.

\subsection{ARCHITECTURE HIERARCHY}

Each architecture identified for SST Retrieval LDMM is given a unique number to represent the architecture's position in the TWRS architecture hierarchy. Figure 3-1 illustrates the hierarchy of the SST Retrieval LDMM architectures, as decomposed from the higher level TWRS architectures. This hierarchy is identical to the TWRS function hierarchy. Figure 2-1 showed the hierarchy of the TWRS functions to the fourth level.

\subsection{ARCHITECTURE DESCRIPTION SHEETS}

An architecture description sheet is provided for each of the architectures identified for SST LDMM during retrieval. The architecture description sheets provide the architecture definitions, alternatives considered, rationale for selection, and other data. The sheets were prepared according to the format used in WHC (1996). 


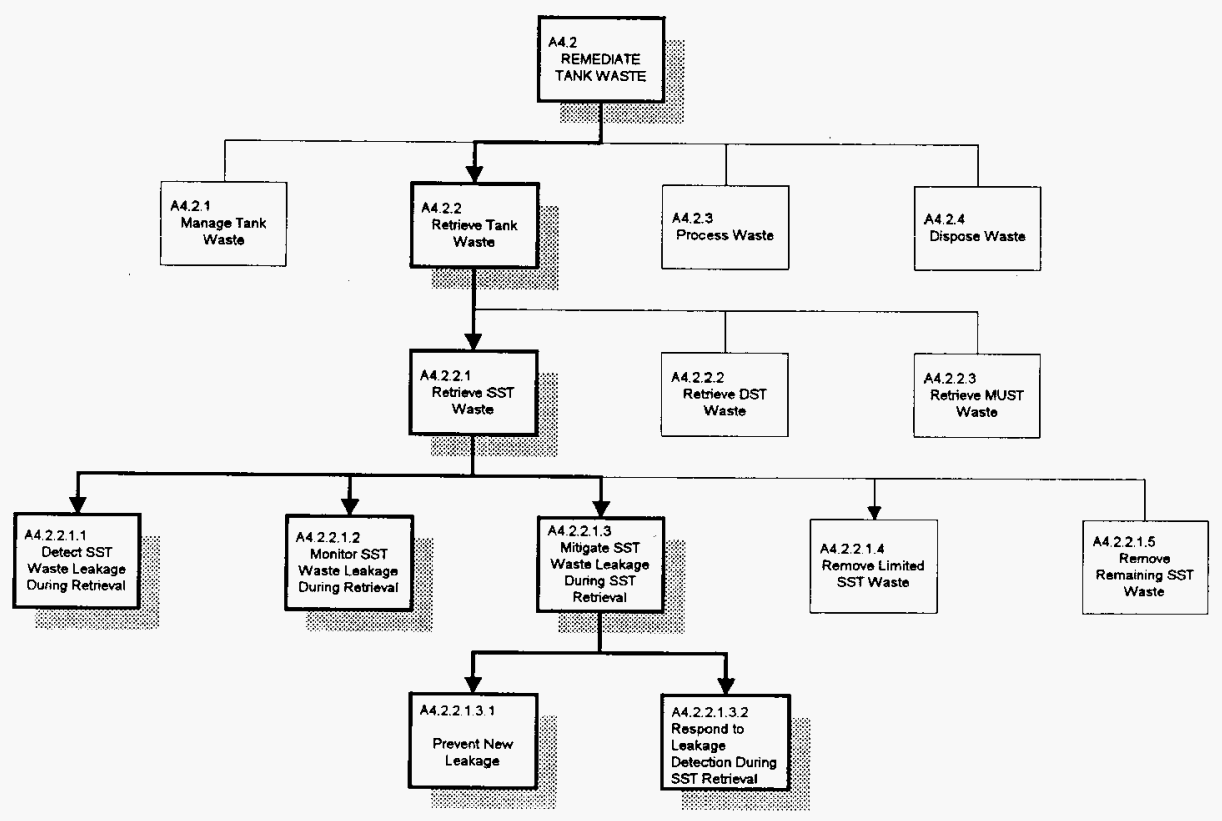

Figure 3-1. SST Waste Retrieval LDMM Architecture Hierarchy. 
I. ARCHITECTURE ID NUMBER: A4.2.2.1.1

II. ARCHITECTURE TITLE: SST Retrieval LDMM - Leakage Detection System

\section{ARCHITECTURE DEFINITION:}

The SST Retrieval LDMM system consists only of technologies that are both available and deployable. The baseline leakage detection system consists of liquid/waste level measurement devices inside the tank (i.e., mass balance) and leakage detection pits (available only on AX Tank Farm tanks) between the primary tank wall and the concrete shell.

\section{ALTERNATIVES CONSIDERED:}

A study by Lewis et al. (1995) identified and screened candidate leakage detection and monitoring technologies that could be applied to SST waste retrieval. This study recommended that six technologies be considered for leakage detection and monitoring application: (1) mass balance using level measurement, (2) tracer gas testing, (3) electrical resistivity tomography (ERT), (4) neutron activation logging, (5) gamma-ray logging, and (6) time domain reflectometry (TDR). An additional detection technology is leak detection pits. The following paragraphs briefly described the alternatives considered.

Mass Balance Using Level Measurement. The mass balance method of leakage detection uses measurements of the liquid level and density in the tank and visual estimates of solids content in the tank to detect changes (leaks) in the mass contained within the overall retrieval system. The primary liquid level and density instrument is the Enraf-Nonius 854 Advanced Technology Gauge (ENRAF). The ENRAF gauge is a liquid level measurement device that consists of a weight (or displacer) at the end of a stainless steel wire. The gauge detects the density or change in the apparent weight of the displacer by buoyancy or by contact with a solid (Schofield 1994). The ENRAF gauge is currently used to collect surface-level readings on 16 of the 149 SSTs, including Tank 241-C-106 (Lewis et al. 1995).

The primary method of measuring the volume of solids remaining in the SST is by visual inspection. Visual inspection is provided by in-tank video. In-tank photography has been used for many years, but only recently has video inspection been used to any extent. Video imaging provides the ability to observe the tank contents during inspection, and allows the viewer to focus in on items of interest as they are detected.

In-tank video is obtained by lowering a camera with a lighting unit into the tank vapor/head space through a riser. The image is displayed on a local screen or monitor and can also be recorded on tape for subsequent viewing and archiving. The ability to determine a solid surface level change from a video image is based on the judgement of the viewer and the presence of reference points in the picture. 
Therefore, the accuracy of solid volume changes determined from video images can range from less than 1 in. to more than 6 in.

The primary advantages of mass balance as a leakage detection and monitoring technology are it is the only system that uses available technologies and it is the only system that has overall acceptance by the compliance agencies as an approved inventory control measure. The primary disadvantages are loss of measurement control during retrieval operations and uncertainties associated with the detection level of the method.

Tracer Gas Testing. Tracer gas testing can potentially detect leaks from SSTs by measuring for the presence of the tracer gas in the soil surrounding the tanks. This technology is the result of combining two mature technologies: tank integrity testing and tracer testing. Tracer gas testing is performed by mixing an inert, volatile chemical concentrate (i.e., a tracer) with a product inside a tank or pipe. The tracer is added to the tank sluice water in very low concentrations (usually a few parts per million). The highly volatile tracer distributes itself throughout the tank, both in the product portion and vapor phase above the product. If a leak occurs, the tracer diffuses from the liquid and disperses into the surrounding soil. The vapor-phase tracer is collected for analysis using a soil vapor extraction system.

The tracer must be specifically selected so that it is compatible with all materials inside the tank but unique to the tank contents and outside environment. The tracer should produce no impact on the physical properties of the tank waste. Low toxicity, nonhazardous, nonbiodegradable, and nonflammable tracers would be used for leak detection (Lewis et al. 1995).

The advantages of tracer gas testing are the improved analytical sensitivity, the direct application during retrieval, and coverage of large monitoring zones. The disadvantage is the delayed response through semi-permeable zones being monitored.

Leak Detection Pits. Leak detection pits are designed to collect any leakage that occurs and migrates along channels in the concrete foundation of the tanks. Four tanks in the AX Tank Farm are equipped with pits to monitor leakage. Radiation detectors, level monitors, and specific gravity instruments are located in the bottom of each pit, and information from this instrumentation is used to detect tank leakage.

The advantage of leak detection pits is the early detection of leakage along the sides and bottom of a tank. The disadvantage is the limited number of pits available for utilization.

Electrical Resistance Tomography. The ERT technology is an innovative leakage detection technology that measures changes in direct current resistivity of the subsurface area or volume. The measurement is made with pairs of electrodes placed into the subsurface, each in electrical contact with the soil formation. Two electrodes are driven by a known current; the resulting voltage difference is measured 
between other pairs of electrodes. Numerical techniques are used to calculate the resistivity distribution in the vicinity of the boreholes and software can be used to construct a two- or three-dimensional map, or tomograph, of the subsurface electrical resistivity/readings. A primary technical concern is the effect of large buried metallic objects located within the area of interrogation (e.g., tank walls, pipes) on the response.

Because most minerals are insulators, current in the subsurface is typically conducted through pore liquids. The formation resistivity is a function of (1) resistivity of the formation water, (2) amount of water present, and (3) pore structure geometry. For leak detection/monitoring, the system will respond primarily to changes in the amount of water present (Lewis et al. 1995).

The advantage of ERT is that it is capable of identifying leakage during operations and retrieval. In addition, the tomographic images have the potential to provide twoand three-dimensional plots of the leak volume and direction of movement. The disadvantage is the potential for electrical interference from buried metallic objects such as tank walls and operating machinery during retrieval.

Borehole Geophysical Logging. Two existing borehole geophysical logging technologies were evaluated and recommended by Lewis et al. (1995) as technologies that could support leakage detection and monitoring: neutron activation logging and gamma-ray logging. These technologies are described in the following sections. Geophysical logging systems typically employ a logging truck, a support crew, and a standard time interval for borehole characterization.

Neutron Activation Logging Neutron activation logging systems can be utilized to monitor tank leak plumes and plume movement by determining the concentration of hydrogen (moisture) in the soil formation by measuring the response to neutron back scatter and measuring the changes in the energy levels. Neutron activation provides a technique to measure moisture content and changes with time for the soil that is in close proximity to the probe.

The advantage of neutron activation logging is that it is easily deployed and can provide a high level of precision for moisture measurements. The disadvantages are that the monitoring is not continuous and the extent of interrogation is short (near field).

Gamma-Ray Logging Gamma-ray logging systems can be utilized to monitor tank leak plumes and plume movement by measuring the radioactive waste that has leaked in the soil. The number and energies of gamma rays emitted are distinctive of the different radionuclides in the waste. Gross gamma detection systems measure the total gamma-ray activity but do not distinguish gamma-ray activity of different energies. Spectral gamma systems measure both the numbers of gamma rays and the energy level of each, permitting a determination of the concentrations of naturally 
occurring and created radionuclides. Plumes are inferred by interpolation between data points.

There are approximately 780 vadose zone monitoring wells in the vicinity of Hanford Site SSTs. These "dry wells" have been utilized by the operating contractors at the Hanford Site for leak detection and plume tracking. These wells have been monitored utilizing gross gamma detection systems to measure and monitor gamma radiation in the soils surrounding the tanks. This leak detection is dependent on radionuclides in the leakage plume. The current success of this system has decreased with the loss of activity of the radionuclides in the soil. An alternative system has been deployed and is currently being evaluated. This alternate system is a spectral gamma logging system and is more sensitive by several orders of magnitude.

The advantages of spectral gamma ray borehole logging are that it can be used to detect leakage, identify the leak source, and track the leakage plume. The major disadvantages are that the monitoring is not continuous and the extent of interrogation is short (near field).

Time Domain Reflectometry. TDR is an established technology for monitoring moisture movement in shallow soils. It can potentially be used to monitor SST tank leaks to the soil in two steps: measuring the propagation velocity of an electromagnetic pulse along a transmission line and converting this measurement to an estimate of soil moisture content (i.e., calibration). The key to this technology is the relative difference in the dielectric constant of most dry geologic materials (approximately 3 to 5) compared to the dielectric constant of water (approximately 80). Precision Moisture Instruments, Inc., produces a 2-m-long (6.6-ft-long) TDR probe that can be driven into the ground surface; this probe has been demonstrated at the Hanford Site as part of the protective barriers program (Lewis et al. 1995).

An advantage of the TDR system is that, properly deployed, it can be used for confirmation of leaks. The disadvantage is that the depth of penetration is short and limited to the vicinity of the sensor (near field).

\section{RATIONALE FOR SELECTION:}

Retrieval of waste from SSTs will create dynamic conditions in the tanks and therefore increase the potential for leakage. Accordingly, enhancements both in operational philosophy and technology are appropriate. The following items will constitute most of the rationale for evaluating and selecting enhancements or alternatives relative to the TWRS baseline.

Public Risk Reduction - Improved detection capability of new SST leakage and improvements in monitoring can reduce public risk by allowing TWRS to take mitigative actions in a timely manner (e.g., avoiding further leakage/migration). The SST leakage or migration that would otherwise occur would eventually impact risk to the public primarily via the groundwater pathway. Accordingly, potential public risk 
reductions will be evaluated using a postulated maximally exposed individual that is exposed via the groundwater pathway. Preliminary risk-based leakage thresholds have been developed for the purpose of ongoing evaluation of technologies (Appendix B).

Worker Risk Reduction - Reductions in worker risk can be achieved by enhancements or alternatives that require less maintenance or operational support in the field. The TWRS program is committed to improving worker safety performance; accordingly, alternatives that reflect this will receive strong consideration.

Cost - The TWRS budget is limited. Enhancements or alternatives will be evaluated in terms of overall cost impact. The evaluation will involve a complete system and life cycle approach.

It is generally expected that the evaluations will favor alternatives that can achieve cost-effective improvements in capability to detect any new SST leakage in the near-field zone. Such capability would allow operations to respond more quickly if actions could be taken to prevent further leakage (e.g., suspend sluicing and remove liquid from the tank). Once leakage occurs and the constituents reach the soil, mitigative actions to prevent further migration become much more difficult and costly than if the leakage could have been prevented. Similarly, once contaminants reach the unsaturated zone or the groundwater zone, mitigative actions can become impossible or cost prohibitive. Therefore, the value of information regarding entrance of new contaminant plumes or further migration of plumes into the unsaturated or groundwater zones is limited.

The SST leakage detection technologies were evaluated by Foster Wheeler (1996). The results from this trade study are presented below. Excluding leakage detection pits that are specific only to the AX Tank Farm, mass balance and ERT leakage detection technologies are applicable or potentially applicable to support past-practice sluicing. Only mass balance can be considered as available and deployable.

Tracer gas is an established leakage detection technology in the petroleum industry but the application of this technology to Hanford Site SSTs has not been developed to a stage that allows any estimate of detection limit. Many issues must be resolved to establish tracer gas as a feasible leakage detection technology for SST applications.

The ERT technology is a leakage detection technology that is in the middle stage of development. It has the potential to achieve low detection limits and to determine leakage volume. Borehole logging and TDR technologies do not meet the functional requirements for leakage detection and are insensitive to leakage in many locations around the tank.

\section{ENABLING ASSUMPTIONS:}

Retrieval of SST waste will be conducted per the current TWRS program baseline using traditional "past-practice" sluicing as the primary approach. 
The SST farms will be closed as landfills with appropriate closure and post-closure supporting activities. The basic closure methodology will consist of structurally stabilizing the tanks (residual remaining in place) followed by installation of a protective surface barrier.

\section{REQUIRED ANALYSES:}

\section{Issue 1 - SST Leakage Threshold Values}

The preliminary SST LTVs provided in Appendix B are intended only as an example for use in initial technology evaluations. As the evaluation process proceeds, a more detailed evaluation of LTVs will be required. Final LTVs should be based on other considerations not addressed in the current evaluation, including:

1. The LTV calculations were based on the assumption that all leakage from the SSTs would contain constituents of concern at concentrations equal to the composition of the tank-specific interstitial liquor. These data were developed for individual tanks based on tank-specific characterization data and simplifying assumptions. The LTVs for all of the SSTs in the B, BX, and BY Tank Farms are quite low and definitely below the leakage detection limits for the baseline LDMM system, indicating that sensitive leakage detection may be advisable in these cases. It was suggested that a risk-based logic be developed for applying LDMM technologies in specific tanks. The logic would be based in part on updated LTVs that reflect risk impacts of adjacent waste sites, and the physical conditions of the tanks and tank farms.

2. Further analyses of drainable liquid samples are required to reduce uncertainty and conservatism. The sample data reported in Van Vleet (1993) were used as a primary source for this document; however, Van Vleet (1993) is considered to be outdated and contains several errors. Accordingly, the next phase of evaluation should include work to ensure the correctness and completeness of the sample data supporting the leakage thresholds.

3. The inventories of COCs associated with sources other than new leakage (e.g., residual waste in tanks following retrieval, waste that has advected into the SST concrete structure, and past leaks) should be reviewed to ensure assumed inventories are consistent with current data.

4. The presence of overlapping contaminant plumes from other sources may increase risk. These sources, including nearby 
cribs, trenches, and ponds, should be considered to help establish the appropriate allocation of risk from each source.

The requirements for SST Retrieval LDMM will have the goal of providing operators with early warning if LTVs are being approached. In addition, the tank closure strategy should include development of leakage thresholds based on a more comprehensive risk assessment and a decision logic to be implemented if/when the established thresholds are exceeded. The risk-based logic for planning what and when LDMM technology should be deployed for individual tanks should be established:

\section{Issue 2 - Design-Basis Leakage Configuration}

The applicability of leakage detection technology depends on its sensitivity to detecting a leak and measuring the volume of leakage. A previous analysis by Lowe et al. (1993) identified a most-likely leak location and quantity. Leakage into the soil may occur from any location on the tank surface below the liquid level, however, resulting in plumes of many possible shapes and sizes.

The LDMM trade study evaluated minimum and maximum leakage detection limits for sets of conditions most advantageous to detection and least advantageous to detection (Foster Wheeler 1996). Wide ranges of leak detection sensitivities were found for the LDMM technologies evaluated. Minimum leakage detection sensitivities appeared attractive in many cases but maximum leakage detection sensitivities were often unacceptably high. No attempt was made to evaluate the probabilities of various leakage locations, sizes, and probabilities to enable prediction of a most-likely leakage detection volume.

Before further work is performed on leakage detection and monitoring technologies, design-basis leakage conditions should be established, including probabilities of occurrence. The probability-weighted effectiveness of the technologies should then be determined and compared to the effectiveness of the baseline LDMM system. This effort may also help to improve leakage detection and monitoring sensor configurations for subsequent testing.

\section{REQUIREMENTS SATISFIED:}

\section{A. Performance Requirements:}

Impact on Other TWRS Functions

In-Tank Deployment

In-Tank Operation

Reliability

Time Frame

Worker Safety/ALARA 


\section{Constraints:}

40 CFR 302.6

DOE 5400.5, Chapter II, 3c(2)

DOE 5820.2A, Chapter I, 3c(3)(b)

WAC 173-303-640(6)(a) and (b)

WAC 173-303-640(7)(d)

WHC-IP-0842, Section 4.6.2 


\section{ARCHITECTURE ID NUMBER: A4.2.2.1.2}
II. ARCHITECTURE TITLE: SST Retrieval LDMM - Leakage Plume Monitoring System

\section{ARCHITECTURE DEFINITION:}

The SST leakage plume monitoring system (near-field zone) consists of drywells and laterals (for some tanks) and the associated sensors deployed to monitor changes in gamma-radiation level and soil moisture level in the soil around the tank.

\section{ALTERNATIVES CONSIDERED:}

TWRS Baseline - The following paragraphs briefly describe the currently available and deployed systems. A more detailed discussion can be found in Technical Bases for the Leak Detection Surveillance of Waste Storage Tanks (Johnson 1995).

Borehole Geophysical Logging. Drywells are vertical boreholes with 6- or 8-in.diameter carbon steel casings, positioned radially around SSTs. A typical drywell installation will extend 50 to $250 \mathrm{ft}$. belowgrade. Drywells do not penetrate to the water table. Monitoring in drywells is generally carried out at a depth of 50 to $150 \mathrm{ft}$. Drywells are used to deploy instruments that can detect changes in gamma-radiation levels over time and moisture content of the soil around the tanks. This information is used, together with primary sensor data, to aid in detecting potential leakage.

Periodic monitoring is performed using four gamma or neutron probes that are lowered into drywells. These instruments provide scan profiles of radiation and moisture in the soil. Tank leakage plume movement is revealed by trending data from successive scans. Probes are lowered to the bottom of the drywell and are withdrawn at a constant rate, while the probe sends a signal to a portable van containing electronics and a cable retrieval system. A profile scan is automatically generated from the data.

The effectiveness of drywell-deployed devices depends, among other things, on the following:

- Proximity of the drywell to the leak

- Proximity of other leaking tanks to the drywell

- Gamma-radioactivity background or moisture level around the drywell

- Liquid migration behavior in the soil (i.e., soil characteristics)

- $\quad$ Radionuclide absorption in the soil

- $\quad$ Size of the leak

- Magnitude of the measured characteristic (i.e., the activity of the radionuclide in the leaked waste solution and the energy of its gamma emission) 
- Sensitivity of the sensing device

- Total measurement precision

- Monitoring frequency.

Because of these limitations, drywells and laterals are no longer used as primary means of leak detection monitoring for a tank.

Leakage Monitoring Laterals. The laterals are similar to drywells but provide a better means of monitoring for the presence of activity in the soil around a tank. Laterals are 4-in.-diameter horizontal steel pipes installed below the concrete tank base, into which 3 -in.-diameter tubing is inserted. The tubes rise to instrument enclosures through vertical caissons adjacent to the tanks. The horizontal portions extend in a fan-like manner 8 to $10 \mathrm{ft}$ beneath the tank (from common caissons) and reach beyond the far side perimeter of the tank. They have been installed under six tanks in the A Tank Farm and under nine of the S Tank Farm tanks. Geiger-Mueller radiation detectors are forced pneumatically from the caisson to the end of the tube, and then retracted by a cable drive mechanism. A radiation profile scan is obtained during withdrawal. Probes deployed into laterals monitor changes in radiation levels of the soil beneath the tanks. Data are gathered by operators in computer-equipped vans and are transmitted to a central computer via the Computer Automated Surveillance System. Graphs of the monitoring data are visually compared to baseline data to determine if changes in radiation levels or profiles have taken place and to detect data trends.

Electrical Resistance Tomography. The ERT technology is an innovative leakage monitoring technology that measures changes in direct current resistivity of the subsurface area or volume. The measurement is made with pairs of electrodes placed into the subsurface, each in electrical contact with the soil formation. Two electrodes are driven by a known current; the resulting voltage difference is measured between other pairs of electrodes. Numerical techniques are used to calculate the resistivity distribution in the vicinity of the boreholes and software can be used to construct a two- or three-dimensional map, or tomograph, of the subsurface electrical resistivity/readings. A primary technical concern is the effect of buried metallic objects located within the area of interrogation (e.g., tank walls, pipes) on the response and the capability to detect low flow, level leakage of the type anticipated during SST retrieval.

Because most minerals are insulators, current in the subsurface is typically conducted through pore liquids. The formation resistivity is a function of (1) resistivity of the formation water, (2) amount of water present, and (3) pore structure geometry. For leak detection/monitoring, the system will respond primarily to changes in the amount of water present (Lewis et al. 1995).

The advantage of ERT is that it is capable of identifying leakage during operations and retrieval. In addition, the tomographic images provide two- and threedimensional plots of the leak volume and direction of movement. The disadvantage is 
the potential for electrical interference from buried metallic objects such as tank walls and operating machinery during retrieval.

Time Domain Reflectometry. TDR is an established technology for monitoring moisture movement in shallow soils. It can potentially be used to monitor SST tank leaks to the soil in two steps: measuring the propagation velocity of an electromagnetic pulse along a transmission line and converting this measurement to an estimate of soil moisture content (i.e., calibration). The key to this technology is the relative difference in the dielectric constant of most dry geologic materials (approximately 3 to 5) compared to the dielectric constant of water (approximately 80). Precision Moisture Instruments, Inc., produces a 2-m-long (6.6-ft-long) TDR probe that can be driven into the ground surface; this probe has been demonstrated at the Hanford Site as part of the protective barriers program (Lewis et al. 1995).

An advantage of the TDR system is that, properly deployed, it can be used for confirmation of leaks. The disadvantage is that the extent of interrogation is short and limited to the vicinity of the sensor (near field).

\section{RATIONALE FOR SELECTION:}

The TWRS baseline retrieval method of "past-practice" sluicing, if implemented, will create dynamic conditions in the tanks and therefore increase the potential for leakage. Accordingly, enhancements both in operational philosophy and technology are appropriate. The following items will constitute most of the rationale for evaluating and selecting enhancements or alternatives relative to the TWRS baseline:

Public Risk Reduction - Improved detection capability of new SST leakage and improvements in monitoring can reduce public risk by allowing TWRS to take mitigative actions in a timely manner (e.g., avoiding further leakage/migration). The SST leakage or migration that would otherwise occur would eventually impact risk to the public primarily via the groundwater pathway. Accordingly, potential public risk reductions will be evaluated using a postulated maximally exposed individual that is exposed via the groundwater pathway. Preliminary risk-based leakage thresholds have been developed for the purpose of ongoing evaluation of technologies (Appendix B).

Worker Risk Reduction - Improvements in worker risk can be achieved by enhancements or alternatives that require less maintenance or operational support in the field. The TWRS program is committed to improving worker safety performance; accordingly, alternatives that reflect this will receive strong consideration.

Cost - The TWRS budget is limited. Enhancements or alternatives will be evaluated in terms of overall cost impact. The evaluation will involve a complete system and life cycle approach.

The SST leakage monitoring technologies were evaluated by Foster Wheeler (1996). There are three technologies that meet or potentially meet the requirements for 
leakage monitoring (specifically the ability to identify the location and movement of a leakage plume). These are ERT, borehole logging, and TDR technologies. Of these, only borehole logging is available and deployable at the Hanford Site.

The ERT in the 8,3 configuration as described in Foster Wheeler (1996) can potentially map and track the three-dimensional movement of a leakage plume over time. This information can be used to quantify the leakage plume. Borehole logging and TDR technologies can only identify and monitor a cross-section or single points within a leakage plume. The successful development and deployment of ERT as both a leakage detection and leakage monitoring tool would provide the additional benefit of addressing the two functions with a single system.

The TDR technology is a commercially available technology; however, its application at the Hanford Site has not been demonstrated. The radius of interrogation is similar to that of borehole logging. The primary benefit derived from the use of TDR technology is the gathering of real-time continuous data using recorders placed outside the tank farms.

\section{ENABLING ASSUMPTIONS:}

Same as A4.2.2.1.1.

VII. REQUIRED ANALYSES:

Same as A4.2.2.1.1.

VIII. REQUIREMENTS SATISFIED:

\section{A. Performance Requirements:}

Deployment

External Operation

Impact on Other TWRS Functions

Monitoring

Reliability

Worker Safety/ALARA

\section{B. Constraints:}

40 CFR 302.6

DOE 5400.1, Chapter IV, 5b

DOE 5400.5, Chapter II, 3c(2)

DOE 5820.2A, Chapter I, 3c(3)(d)

DOE 5820.2A, Chapter III, 3k

DOE 5820.2A, Chapter I, 3c(3)(a)

WAC 173-160-020 


\section{WHC-SD-WM-FRD-021 REV. 1}

WAC 173-303-640(6)(a) and (b)

WHC-IP-0842, Section 4.6.2 
WHC-SD-WM-FRD-021 REV. 1

This page intentionally left blank. 


\section{ARCHITECTURE ID NUMBER: A4.2.2.1.3.}

II. ARCHITECTURE TITLE: SST Retrieval LDMM - Leakage Mitigation System

\section{ARCHITECTURE DEFINITION:}

Leakage can be mitigated by controlling the use and amount of liquid during sluicing. Past-practice sluicing (adding water) will increase the potential for leakage and, therefore, will be carefully managed as part of the leakage mitigation effort. The design of the retrieval system also presents a possibility to provide leakage mitigation potential, by providing equipment and features that allow the retrieval process to go as fast as possible without interruptions. Such features would minimize down time and ensure that backup systems are available when needed. Maintenance of liquid levels as low as possible throughout the sluicing process and reduction of the duration for sluicing to as short as possible further reduce leakage potential. Experience with the sluicing process, as more and more tanks are processed, will develop the "art" of sluicing and increase the operational understanding about what works the best, fastest, and most efficiently.

\section{ALTERNATIVES CONSIDERED:}

Subsurface barriers and other options for mitigating SST leakage that may result from retrieval operations were evaluated by Treat et al. (1995) in support of Tri Party Agreement Milestone M-45-07, "Complete Evaluation of Sub-surface Barrier Feasibility" (September 1994).

A number of alternative architectures were considered for application to this function:

- $\quad$ Optimized past-practice sluicing involves use of past-practice sluicing in sound tanks. No action will be taken to confine soil contamination resulting from previous SST leakage during waste retrieval activities. This is the current architecture.

- Subsurface barriers were considered as an alternative for "New Leakage Prevention;" see A4.2.2.1.1.

- $\quad$ Limited sluicing, robotic sluicing, and mechanical sluicing were considered as alternatives for "Leakage Operational Response;" see A4.2.2.1.3.2.

\section{RATIONALE FOR SELECTION:}

The current TWRS program baseline includes retrieval of SST waste in sound tanks using incremental improvements to past-practice sluicing to mitigate the threat of leakage from SSTs during retrieval activities. However, the potential for large leaks during retrieval still exists. 
The primary approach currently envisioned for retrieval of the SST waste is hydraulic or past-practice sluicing. The sluicing operations will typically add some level of working liquid to the tank to mobilize the solidified salt cakes and sludges. The design life of the tanks has expired and the continued integrity of the tank containment boundaries is in question. Concerns exist regarding additional leakage that may result due to the hydraulic head and fluid dynamic forces impacting the tank shells during retrieval. The robotic arm-based confined sluicing method for retrieval would likely reduce the chances of leakage; however, leakage during retrieval may still occur in areas where the tank containment structure has deteriorated significantly.

External emplacement of subsurface barriers has been considered as a potential leakage mitigation option. Previous studies (Treat et al. 1995) have shown that the use of subsurface barriers around underground storage tanks is not technically mature and the final effect, even if deployment were successful, would only be one of shifting, and possibly concentrating, the leakage front. As a result of the previous studies, subsurface barriers are not considered to be a viable component of the retrieval strategy regarding leakage mitigation or control.

\section{ENABLING ASSUMPTIONS:}

Same as A4.2.1.1.

VII. REQUIRED ANALYSES:

Same as A4.2.1.1.

\section{REQUIREMENTS SATISFIED:}

\section{A. Performance Requirements:}

Impact on Other TWRS Functions

In-Tank Deployment

In-Tank Operation

Worker Safety/ALARA

\section{Constraints:}

40 CFR 141.15 and 141.16

DE 5820.2A, Chapter III, 3k

DOE 5400.1, Chapter IV, 5b

DOE 5400.5, Chapter II, 3c(2)

DOE 5400.5, Chapter II, 1d(3)

DOE 5820.2A, Chapter I, 3c(4)(a)

DOE 5820.2A, Chapter I, 3c(4)(b)

DOE 5820.2A, Chapter I, 3c(4)(c)

DOE 5820.2A, Chapter I, $3 \mathrm{c}(3)$ (d) 
DOE 5820.2A, Chapter I, 3c(3)(c)

DOE 5820.2A, Chapter I, 3c(3)(a)

DOE 5820.2A, Chapter I, 3c(3)(b)

WAC 173-160-020

WAC 173-303-640(4)(e)(i)

WAC 173-303-640(6)(a)

WAC 173-303-640(7)(c)(i)

WAC 173-303-640(7)(d) 
This page intentionally left blank. 
I. ARCHITECTURE ID NUMBER: A4.2.2.1.3.1

1I. ARCHITECTURE TITLE: SST Retrieval LDMM - New Leakage Prevention

III. ARCHITECTURE DEFINITION:

Optimized past-practice sluicing waste retrieval using incremental improvements to past-practice sluicing in sound tanks will be used to mitigate new leakage.

IV. ALTERNATIVES CONSIDERED:

- Optimized past-practice sluicing involves incremental improvements to past-practice sluicing waste retrieval. This is the current architecture.

- Subsurface barriers involves the installation of barrier material into the soil immediately surrounding the tank structure forming a seal. This barrier would prevent new leakage and thereby prevent new soil contamination. A more detailed description of this alternative can be found in Treat et al. (1995).

\section{RATIONALE FOR SELECTION:}

Same as A4.2.1.3.

VI. ENABLING ASSUMPTIONS:

Same as A4.2.2.1.3.

VI. REQUIRED ANALYSES:

Same as A4.2.2.1.3.

VII. REQUIREMENTS SATISFIED:

\section{A. Performance Requirements:}

Same as A4.2.2.1.3.

B. Constraints:

Same as A4.2.2.1.3. 
This page intentionally left blank. 
I. ARCHITECTURE ID NUMBER: A4.2.2.1.3.2.

II. ARCHITECTURE TITLE: SST Retrieval LDMM - Leakage Operational Response System

III. ARCHITECTURE DEFINITION:

The leakage operational response is a graded approach to a confirmed or suspected SST leak. This approach is based on the leakage size and leakage rate (relative to the LTV), whether there is existing contamination in the soils surrounding the tank, and the amount of waste left in the tank.

If a high rate of leakage is inferred using leakage detection, the preferred operational response would be different than in the case of a low rate of leakage. The response for a high leakage rate is to pump out the tank as quickly as possible and rely on mechanical retrieval, robotic sluicing, or some other alternative to complete cleanout of the tank. In the case of a low rate of leakage, or where the LTV is high, the appropriate action would be to continue sluicing at the highest rate possible and use leakage detection to confirm that the leakage does not exceed the LTV or a present operations response level. There is also the possibility that the leakage volume will remain below the detection level or that very large and rapid leakage will occur at a rate that precludes usefulness of all available operational response. There are no effective operational responses for these cases. This system approach was described in Stuart et al. (1996).

\section{ALTERNATIVES CONSIDERED:}

The operational response to a leak during retrieval is limited to continuing waste retrieval or stabilize the SST by pumping out as much liquid as possible followed by final retrieval using an alternative technology. The alternatives considered include the baseline past-practice sluicing, limited sluicing, robotic sluicing, and mechanical retrieval.

- Past-practice sluicing was conducted in two waste retrieval campaigns:

(1) from 1952 to 1957 , as part of a system to recover uranium from the waste tanks and (2) from 1962 to 1978 , as part of a system to recover strontium. The retrieval techniques utilized sluicing and slurry pumping. In general the technique was successful, but was plagued with equipment failures. Optimized past-practice sluicing would consist of improved and updated retrieval and sluicing techniques that incorporate current administrative, radiological, and regulatory controls. Technical improvements include advanced nozzle designs, improved pumping systems, recirculation of the supernatant, and improved heating, ventilating, and air conditioning systems. 
- Limited sluicing is a waste mitigation technique proposed in Stuart et al. (1996). A layer of sludge/saltcake would be maintained on the vertical walls of the tanks to avoid further damage to the tank shell and to help retain whatever natural seal exists. Optimized past-practice sluicing and a telescoping pump would be used. A high degree of control would be exercised over the flow and direction of the nozzle spray when sluicing near the tank walls. Improved video monitoring would be employed to track and verify progress.

- Robotic sluicing would employ a type of robotic armed-based retrieval system that was first investigated at the Hanford Site in the mid-1970s. The technology is under development, but has not been tested in an actual Hanford Site SST (Treat et al. 1995). An attachment to the end of the robotic arm called an end effector would use high-pressure water jets to dislodge the waste. After the sludge is dislodged, the slurried mixture would be immediately vacuumed through a hose to an air separation system. Following separation the waste would proceed to a processing system.

- Mechanical retrieval, designed for removal of solid waste and debris by mechanical means as opposed to hydraulic means, is one of the armbased retrieval methods currently under consideration for use in the SSTs. It is one of several methods of retrieving waste from SSTs that have been investigated at the Hanford Site since the mid-1970s.

Mechanical retrieval would use a scoop-like end effector affixed to the end of the robotic arm for waste retrieval. The end effector would be capable of mechanically excavating the solid waste in the tank. A jackhammer end effector may be necessary for breaking up the rock-like saltcake and heels of sludge known to exist in some tanks. The excavated waste would be placed by the robotic arm into an in-tank mechanical waste conveyance system and removed from the SST for further processing.

\section{V . RATIONALE FOR SELECTION:}

Only past-practice sluicing, which is the baseline retrieval technology for tanks that are sound and have not previously leaked, is available, deployable, and proven reliable for waste retrieval. Planned equipment and procedural enhancements are expected to further improve waste retrieval rates using past-practice sluicing. This will reduce the sluicing time frame during which leakage can occur, thereby reducing overall leakage and public health risk.

The limited sluicing alternative, which is based on fundamental mechanical principles but has not been demonstrated in an SST, may prove to be effective in mitigating leakage. Robotic sluicing and mechanical retrieval may reduce leakage and associated risk by limiting the amount of drainable water in a tank. However, these technologies 
are not available and are unproven for applications similar to retrieval of waste from SSTs.

VI. ENABLING ASSUMPTIONS:

Same as A4.2.1.3.

VU. REQUIRED ANALYSES:

Same as A4.2.2.1.3.

VIII. REQUIREMENTS SATISFIED:

A. Performance Requirements:

Same as A4.2.2.1.3.

B. Constraints:

Same as A4.2.2.1.3. 
This page intentionally left blank. 


\subsection{REFERENCES}

Anderson, G., 1993, "Tank Waste Barriers, M-06-00" (letter 9303063 to J.D. Bauer, U.S. Department of Energy, Richland Operations Office, March 29, 1993), Washington State Department of Ecology, Olympia, Washington.

Anttonen, J.H., 1992, "TWRS National Technology Workshop, June 29, 30 and July 1, 1992" (letter 92-TRB-123 to addressees, August 17, 1992), U.S. Department of Energy, Richland Operations Office, Richland, Washington.

Camaioni, D.M., W.D. Samuels, S.A. Clauss, B.D. Lenihan, K.L. Wahl, J.A. Campbell, and W.J. Shaw, 1995, FY 95 Waste Aging Studies, PNL-10794, Battelle Pacific Northwest Laboratory, Richland, Washington.

Cruse, J.M., 1994, Functions and Requirements for Single-Shell Tank Leakage Mitigation, WHC-SD-WM-FRD-019, Rev. 0., Westinghouse Hanford Company, Richland, Washington.

Cruse, J.M., D.F. Iwatate, K.S. Tollefson, R.L. Treat, T.L Trenkler, and R.E. Lewis, 1995, Functions and Requirements for Hanford Single-Shell Tank Leakage Detection and Monitoring, WHC-SD-WM-FRD-021, Rev. 0, Westinghouse Hanford Company, Richland, Washington.

Delaney, C.D., K.A. Lindsey, and S.P. Reidel, 1991, Geology and Hydrology of the Hanford Site: A Standardized Text for Use in Westinghouse Hanford Company Documents and Reports, WHC-SD-ER-TI-003, Westinghouse Hanford Company, Richland, Washington.

Ellis, S.H., 1992, Waste Tank Project Administration, WHC-IP-0842, Rev. 0, Westinghouse Hanford Company, Richland, Washington.

Erickson, L., 1995, Supplemental Direction Regarding the Implementation of FY 1995 Retrieval, Treatment, and Immobilization, and System Engineering Program Areas, 95-RTI-003, U.S. Department of Energy, Richland Operations Office, Richland, Washington.

Foster Wheeler Environmental, 1996, Trade Study of Leakage Detection, Monitoring, and Mitigation Technologies to Support Hanford Single-Shell Tank Waste Retrieval, WHCSD-WM-ES-379, Rev. 0, prepared by Foster Wheeler Environmental Corporation for Westinghouse Hanford Company, Richland, Washington.

Gibbons, P.W., J.C. Sabin, M.C. Prather, and S. Krieg, 1993, Review of Prior Single-Shell Tank Waste Retrieval Process Studies, WHC-SD-WM-ES-252, Rev. 0, Westinghouse Hanford Company, Richland, Washington. 
Hagmann, D.B., 1995, Approach Plan for the Initial Single-Shell Tank Retrieval System Definition Effort, WHC-SD-WM-AP-039, Westinghouse Hanford Company, Richland, Washington.

Hanlon, B.M., 1996, Tank Farm Surveillance and Waste Status Summary Report for October 1995, WHC-EP-0182-91, Westinghouse Hanford Company, Richland, Washington.

Johnson, 1995, Technical Bases for the Leak Detection Surveillance of Waste Storage Tanks, WHC-SD-WM-TI-573, Rev. 1, Westinghouse Hanford Company, Richland, Washington.

Klem, M.J., 1990, Inventory of Chemicals Used at Hanford Production Plants and Support Operations (1944-1980), WHC-EP-0172, Rev. 1, Westinghouse Hanford Company, Richland, Washington.

Lewis, R.E. and S.S. Teel, 1994, A Survey of Existing and Emerging Technologies for External Detection of Liquid Leaks at the Hanford Site, PNL-10176, Pacific Northwest Laboratory, Richland, Washington.

Lewis, R.E., S.S. Teel, W.H. Wegener, and D.F. Iwatate, 1995, A Survey and Description of Candidate Technologies to Support Single Shell Tank Waste Retrieval, Leak Detection, Monitoring, and Mitigation, PNL-10755, Pacific Northwest Laboratory, Richland, Washington.

Lindsey, K.A., B.N. Bjornstad, J.W. Lindberg, and K.M. Hoffman, 1992a, Geologic Setting of the 200 East Area: An Update, WHC-SD-EN-TI-012, Rev. 0, Westinghouse Hanford Company, Richland, Washington.

Lindsey, K.A., M.P. Connelly, and B.N. Bjornstad, 1992b, Geologic Setting of the 200 West Area: An Update, WHC-SD-EN-TI-008, Rev. 0, Westinghouse Hanford Company, Richland, Washington.

Lowe, S.S., W.C. Carlos, J.J. Irwin, R. Khaleel, N.W. Kline, J.D. Ludowise, R.M. Marusich, and P.D. Rittman, 1993, Engineering Study of Tank Leaks Related to Hydraulic Retrieval of Sludge from Tank 241-C-106, WHC-SD-WM-ES-218, Rev. 1, Westinghouse Hanford Company, Richland, Washington.

Peck, L.G., 1996, Systems Engineering Management Plan, WHC-SD-WM-SEMP-002, Rev. 0, Westinghouse Hanford Company, Richland, Washington.

Reidel, S.P., K.A. Lindsey, and K.R. Fecht, 1992, Field Trip Guide to the Hanford Site, WHC-MR-0391, Rev. 0, Westinghouse Hanford Company, Richland, Washington.

RL, 1993, Hanford Mission Plan, Volume 1 - Site Guidance, DOE/RL-93-08, U.S. Department of Energy, Richland Operations Office, Richland, Washington. 
Schofield, J.S., 1994, Technical Bases for the Leak Detection Surveillance of Waste Storage Tanks, WHC-SD-WM-TI-573, Rev. 0, Westinghouse Hanford Company, Richland, Washington.

Schmittroth, F., F.M. Mann, T.H. DeLorenzo, and P.A. Rittman, 1993, Risk-Based Preliminary Assessment Supporting Closure of the Hanford Site Single-Shell Tanks as Landfills, WHC-EP-0692, Westinghouse Hanford Company, Richland, Washington.

Stuart, R.J., R.L. Fritz, B.D. Groth, T.L. Pehl, 1996, Operational Tank Leak Detection and Mitigation During Retrieval, Report No. 951126-001, Prepared by the ARES Corporation for Westinghouse Hanford Company, Richland, Washington.

Treat, R.L., B.B. Peters, R.J. Cameron, W.D. McCormack, T. Trenkler, M.F. Walters, J.K. Rouse, T.J. McLaughlin, and J.M. Cruse, 1995, Feasibility Study of Tank Leakage Mitigation Using Subsurface Barriers, WHC-SD-WM-ES-300, Rev. 1, Westinghouse Hanford Company, Richland, Washington.

Van Vleet, R.J., 1993, Radionuclide and Chemical Inventories for the Single Shell Tanks, WHC-SD-WM-TI-565, Westinghouse Hanford Company, Richland, Washington.

Wagoner, J.D., 1992, "National Environmental Policy Act (NEPA) Categorical Exclusion (CX) Determination: Site Characterization and Environmental Monitoring, Hanford Site, Richland, Washington" (memorandum 9208799 to C.M. Borgstrom, U.S. Department of Energy, December 4, 1992), U.S. Department of Energy - Richland Field Office, Richland, Washington.

WHC, 1991, Hanford Site Solid Waste Acceptance Criteria, WHC-EP-0063-3, Westinghouse Hanford Company, Richland, Washington.

WHC, 1992, Operating Specifications for Single-Shell Waste Storage Tanks, OSD-T-151-00013, Revision D-1, Westinghouse Hanford Company, Richland, Washington.

WHC, 1994, Operating Specifications for Tank Farm Leak Detection, OSD-T-151-00031, Rev. A-1, Westinghouse Hanford Company, Richland, Washington.

WHC, 1995, Hanford Site Tank Farms Facilities Interim Safety Basis, WHC-SD-WM-ISB001, Rev. 0I, Westinghouse Hanford Company, Richland, Washington.

WHC, 1996, Tank Waste Remediation System Functions and Requirements Document, WHCSD-WM-FRD-020, Rev. 0, Westinghouse Hanford Company, Richland, Washington. 
This page intentionally left blank. 
WHC-SD-WM-FRD-021 REV. 1

APPENDIX A

GENERAL REQUIREMENTS APPLICABLE TO TANK FARMS 
WHC-SD-WM-FRD-021 REV. 1

This page intentionally left blank. 


\section{A.1.0 GENERAL REQUIREMENTS}

In addition to the requirements allocated to specific functions as identified in the document, the following general requirements shall apply to leakage detection, monitoring, and mitigation during retrieval of SST waste. They are included here as general requirements because they would apply to design, development, and deployment of any system within the Hanford Site tank farms, regardless of function. Table A-1 shows the general requirements discussed in this appendix.

\section{A.1.1 DESIGN REQUIREMENTS}

The design of systems, structures, and components shall be in accordance with U.S. Department of Energy (DOE) Order 6430.1A, General Design Criteria, except where formal criteria deviations are approved by the cognizant DOE authority. The requirements of the "99" Sections and of Division 13 of that order, as applied to nonreactor nuclear facilities and radioactive liquid waste facilities, are applicable.

The design of systems, structures, and components shall comply with the requirements of DOE, Richland Operations Office (RL) Implementing Procedure (RLIP) 6430.1C, Hanford Plant Standards (HPS) Program, including but not limited to Standard Design Criteria specifically referenced in this document.

Systems, structures, and components important to safety shall be designed to withstand the effects of natural phenomena, including seismic, wind, and missile events. A graded approach to applying natural phenomena criteria shall be employed as described in DOE Order 5480.28, Natural Phenomena Hazards Mitigation, and Hanford Plant Standards, Standard Design Criteria HPS-SDC-4.1, Revision 11, Design Loads for Facilities.

Energy conservation shall be considered in the selection of components using the criteria given in DOE Order 6430.1A, with the objective to minimize consumption of nonrenewable energy sources and to encourage the use of renewable energy sources.

Systems, facilities, and services shall be designed for year-round operation.

Existing Site utilities shall be used to the maximum extent practicable.

\section{A.1.2 SAFETY REQUIREMENTS}

Structures, systems, and components are categorized into safety classes, as defined in WHCCM-1-3, Management Requirements and Procedures, MRP 5.46, "Safety Classification of Systems, Components and Structures." The safety classes for systems, structures, and components will be determined during a Hazard Analysis and Preliminary Safety Evaluation. 
WHC-SD-WM-FRD-021 REV. 1

Table A-1. SST Leakage Detection and Monitoring General Requirements.

\begin{tabular}{|l|l|}
\hline \multicolumn{1}{|c|}{ Requirement } & \multicolumn{1}{c|}{ Subject } \\
\hline \hline 10 CFR 835 & Occupational Radiation Protection \\
\hline 29 CFR 1910 & Occupational Safety and Health Standards \\
\hline ASME NQA-1 & Quality Assurance \\
\hline DOE-RL 5480.4C & ES\&H \\
\hline DOE-RL 6430.1C & General Design \\
\hline DOE 5400.1 & Environmental Protection \\
\hline DOE 5480.10 & Industrial Hygiene Program \\
\hline DOE 5480.28 & Natural Phenomena Hazards Mitigation \\
\hline DOE 5480.4 & ES\&H \\
\hline DOE 5480.7A & Fire Protection \\
\hline DOE 6430.1A & General Design \\
\hline PL 101-510 & Safety Measures - Watch List Tanks \\
\hline WAC 246-247 & Radiation Protection - Air Emissions \\
\hline WHC-CM-7-5 & Environmental Compliance \\
\hline WHC-EP-0063 & Solid Waste Acceptance Criteria \\
\hline
\end{tabular}


The design of systems, structures, and components shall ensure that a single failure does not result in the loss of capability of a safety class system to accomplish its required safety functions. To protect against single failures, the design shall include appropriate redundancy and shall consider diversity to minimize the possibility of concurrent common-mode failures of redundant items.

Personnel exposure to radiation and hazardous substances shall be mitigated by employing the as low as reasonably achievable (ALARA) process, which incorporates shielding and design configuration. Shielding shall be provided in accordance with the exposure limits of DOE Orders 5400.5, Radiation Protection of the Public and the Environment, and 5480.11, Radiation Protection for Occupational Workers.

Equipment and facilities shall be designed in accordance with the safety requirements of the . following:

\section{CFR 835, Occupational Radiation Protection}

29 CFR 1910, Occupational Safety and Health Standards

DOE Order 5480.4, Environmental Protection, Safety, and Health Protection Standards

RL Order 5480.4C, Environmental Protection, Safety, and Health Protection Standards for $R L$

DOE Order 5480.7A, Fire Protection

RL Implementing Directive (RLID) 5480.7, Fire Protection

DOE Order 5480.10, Contractor Industrial Hygiene Program

RLIP 5480.10, Industrial Hygiene Program

\section{A.1.3 QUALITY ASSURANCE REQUIREMENTS}

A project-specific quality assurance program plan (QAPP) shall be developed during Conceptual Design of any project implemented systems and approved/released prior to definitive design. The QAPP will implement the quality criteria of DOE Order 5700.6C, Quality Assurance, through the selective and judicious use of ASME NQA-1, Quality Assurance Program Requirements for Nuclear Facilities. The quality program shall provide for a graded approach to the selective application of those active requirements. The basis for establishing that graded approach is the safety classification assigned to systems, structures, and components as described in Section 1.2 above. 
Quality assurance (QA)/quality control (QC) activities for all contractors involved in design, construction, inspection, testing, and acceptance shall be executed in accordance with the QAPP. The QAPP shall be used by any design contractors to develop verification criteria in design documents, (drawings, specifications, test procedures), and to define QA interfaces for specific requirements and responsibilities on the project.

\section{A.1.4 ENVIRONMENTAL REQUIREMENTS}

The project shall comply with the requirements of DOE Order 5400.1, General Environmental Protection Program, as implemented by RLIP 5400.1, General Environmental Protection Program, and with the requirements of WHC-CM-7-5, Environmental Compliance.

The following paragraphs identify potential regulatory permits, approvals, and/or requirements applicable to installation and operation of leak detection and monitoring equipment within the SSTs or outside of the SSTs.

\section{National Environmental Policy Act (NEPA) Documentation - Title 10, CFR 1021}

A NEPA review will be required for all proposed actions at the Hanford Site. Documentation of the completed NEPA review process could include an Environmental Impact Statement (EIS), an Environmental Assessment (EA) or a Categorical Exclusion (CX). The EIS is required for proposed actions that could significantly affect the quality of the human environment. In cases where the need for an EIS is uncertain, an EA is prepared. A CX is issued by RL if the proposed action clearly would have no significant impact on the quality of the human environment. However, any action determined categorically excludable must be documented.

\section{State Environmental Policy Act (SEPA) - WAC 197-11}

Any action requiring a permit or license approval will require a SEPA evaluation. The SEPA applies to any project or proposal that meets the definition of an "action" in the SEPA rules. The SEPA rules define an "action" in WAC 197-11-704 as being either project or non-project actions. Project actions involve a decision on a specific project, such as a construction or management activity located in a defined geographic area. Projects are limited to the Washington State Department of Ecology's (Ecology's) decision to license, fund, or undertake any action that will directly modify the environment.

The SEPA requirements are triggered when a covered action is proposed that requires permit or license approval. For the purposes of constructing a leakage detection and monitoring system, Ecology will be the lead agency. The SEPA compliance must be completed before Ecology makes a decision on a permit or license, and a SEPA checklist must accompany the permit or license when transmitted to Ecology for approval. A permit or license may be conditioned or denied based upon information contained in the SEPA checklist or subsequent 
SEPA documentation. Compliance with SEPA is required for covered actions in addition to the normal permits or approvals that may be required for a given project. A standard SEPA checklist is provided in WAC 197-11-960.

\section{Controls for New Sources of Toxic Air Pollutants (TAPs) - WAC 173-460}

The WAC 173-460 limits emissions of approximately 690 TAPs. An owner or operator of a facility that will be a new TAP source is required to submit a notice of construction (NOC) to Ecology to allow for a new source review. This NOC and new source review will apply only to the new emissions unit and the TAPs emitted from that unit. These regulations require emissions of TAPs to be quantified in such detail as to determine compliance with the rule's provisions. After emissions have been quantified, TAP emissions that have increased (or if there were previously no emissions from the source) are compared to the small quantity emission rates. If the emission rate of the TAP is less than the small quantity emission rate, an NOC is not required. However, an NOC is required when the emission rate is above the associated small quantity emission rate.

The WAC 173-460 regulations also specify the level of control technology that must be implemented, depending on whether the sources are modifications to exiting units or new sources. For existing sources, only reasonably available control technology for toxics (T-RACT) is required. However, best available control technology for toxics (T-BACT) is required for increases in emissions from specified new sources. The NOC, including the determination of T-BACT, must be approved by Ecology before beginning construction of the new source.

\section{National Emission Standards for Hazardous Air Pollutants (NESHAPs), 40 CFR 61, Subpart H}

Radionuclides were designated as hazardous air pollutants in Section 112 of the Clean Air Act on December 27, 1979, and in U.S. Environmental Protection Agency (EPA) promulgated standards for radionuclide emissions on February 6, 1985. Therefore, radionuclide air emissions associated with full scale construction or operation of an underground barrier system will be regulated under 40 CFR 61, Subpart H, "National Emission Standards for Hazardous Air Pollutants (NESHAPs) of Radionuclides Other Than Radon from Department of Energy Facilities". Any new stationary source of radionuclide emissions is subject to a preconstruction review and approval by the EPA, Region X. Also, any new physical or operational activity that will provide any increase in potential emissions of radionuclides is defined as a modification that also may require approval.

\section{Radiation Protection--Air Emissions (RAEP), WAC 246-247}

The State of Washington Department of Health (DOH), Air Emissions and Defense Waste Section is authorized to implement regulations regarding radionuclide emissions from DOE facilities. According to WAC 246-247-050, the owner or operator of each source of airborne radionuclide emissions, including DOE facilities, shall register the source with the 
department. Upon a determination that registration of a particular source meets Ecology and DOH regulations, the DOH will issue a permit authorizing the emission source with such appropriate terms and limitations. Permits are required by WAC 246-247-060 for the release of radionuclides to the ambient air.

According to WAC 246-247-070, construction shall not begin on any new source that is required to be registered, until an NOC has been approved. The construction, installation, or establishment of a new regulated source of emissions shall utilize best available radionuclide control technology (BARCT).

\section{Air Operating Permit - WAC 173-401}

The WAC 173-401 establishes the elements of a comprehensive Washington State air operating permit program consistent with the requirements of Title $\mathrm{V}$ of the Federal Clean Air Act. A sitewide permit is required for processes within the Hanford Facility. This permit will address both radioactive and nonradioactive airborne emissions from all emission units that are above the listed threshold limits defined as significant under the Act. The airborne emissions include, but are not limited to, criteria pollutants and hazardous air pollutants (including radionuclides). In this regulation, Ecology also has established thresholds for regulated pollutants below which emissions would be considered insignificant for the purposes of the operating permit program. Ecology has proposed new sections to Chapter 173-401 to define Insignificant Emissions Units (IEUs) and activities. Categorically exempt units/activities may be omitted from the permit. Other IEU items/activities must be listed on the permit, but are exempt from the administrative requirements of the permit.

The permit will establish emission limits and conditions of operation restrictions for major sources on the Hanford Site. If a new NOC is required and an emissions unit becomes operational after the permit is issued by the state, a permit revision will be required within twelve months after commencing operation. This application for modification shall be prepared in accordance with WAC 173-401-725. The NOC and permit modification can be sought concurrently. Any NOC application and associated documentation should be retained for future use in the Air Emissions Inventory that will be supporting the preparation of the Title V Air Operating Permit application.

\section{State Waste Discharge Permit (SWDP) Program, WAC 173-216}

An SWDP is required before waste materiais from industrial, commercial, and municipal operations are discharged into ground and surface waters of the state and into municipal sewerage systems. An SWDP is not required for discharges of pollutants into navigable waters covered by a National Pollutant Discharge Elimination System (NPDES) permit program or for injection of fluids through wells, which is regulated by the Underground Injection Control Program. 


\section{Dangerous Waste Regulations - WAC 173-303; 40 CFR 264, 265, 270}

The Hanford Site SSTs are currently operating in a manner consistent with interim status. The EPA has determined that any unit that was in existence on the effective date of the Resource Conservation and Recovery Act (RCRA) regulations (November 19, 1980) and that filed a RCRA Section 3010 notification would be treated as if it had been issued a permit. These types of facilities are referred to as interim status facilities. Because the SSTs do not meet current regulatory requirements for dangerous waste treatment and storage tanks, they will be closed under interim status and a Part B permit required by WAC 173-303-806 will not be developed.

The WAC 173-303 establishes the requirements applicable to generators, transporters, and owners or operators of treatment, storage, and disposal (TSD) units. The WAC 173-303$400(3)$ (a) specifies that the requirements for interim status TSD units shall be those requirements set forth by the EPA in 40 CFR 265, Subparts F through R. Additionally, interim status TSD units must comply with Washington State's land disposal restrictions established in WAC 173-303-140 and the facility requirements in WAC 173-303-280 through 173-303-440.

Listed waste contaminated environmental media that is excavated or generated during installation of a leakage detection and monitoring system will require management as a listed dangerous waste unless Ecology determines that the soil in question does not contain listed waste constituents above residential health-based standards. To get a contained-in determination, a sampling and analysis plan must be developed and approved by Ecology and samples of sufficient quantity and quality must be obtained to characterize the media in question. Ecology will use the data obtained from the sampling efforts to make a contained-in determination. The management of listed waste contaminated environmental media and any other secondary waste generated during installation of leak detection and monitoring equipment must be carefully considered prior to generation. It is anticipated that any type of leak detection and monitoring equipment selected will generate a certain amount of secondary waste, in the form of contaminated media and others, that will require management as a dangerous waste. Minimizing this waste generation will be vital from a cost and scheduling perspective.

\section{Cultural Resource Review (CRR) - 36 CFR 800}

A CRR shall be performed before initiating any potential surface-disturbing activities onsite, or if any modifications are planned for any facility with the potential for inclusion on the National Register of Historic Places.

\section{Excavation Permit - 36 CFR 800}

An excavation permit is required before initiating any potential surface-disturbing onsite activities. 


\section{Endangered Species Approval - 50 CFR 402.6}

A. site assessment should be made to determine whether any planned activities have the potential to disturb any critical habitat used by threatened and endangered species.

Preoperational Monitoring of Facilities, Sites, and Operations - DOE Order 5400.1

Note: $\quad$ For more information see the Environmental Compliance Manual WHC-CM-7-5, Section 5.0, 5.4.2.1.g \& h, Section 8.0, 8.5.1.7, and Section 9.0,9.3.1.3.

An environmental study shall be conducted before startup of a site, facility, or process that has the potential for significant adverse environmental impact. This study should begin not less than one year and preferably two years before startup, so seasonal changes can be evaluated.

\section{Radiation Protection Standards - DOE Order 5400.5}

This DOE Order establishes standards and requirements that must be followed to protect members of the public and environment against undue risk from radiation. The general environmental protection program requirements are established in DOE Order 5400.1. DOE Order 5400.1 requires that all DOE Sites prepare an environmental monitoring plan. DOE/RL 91-50, Environmental Monitoring Plan, includes DOE/EH-0173T, Environmental Regulatory Guide for Radiological Effluent Monitoring and Environmental Surveillance, which provides specific guidance regarding environmental monitoring activities.

\section{A.1.5 DECONTAMINATION AND DECOMMISSIONING}

Existing equipment that is being replaced shall be decommissioned as necessary after the new systems are operational. Abandonment of equipment in place is permissible when that option can be shown to be the best economic and technical approach. Equipment and facilities shall be designed to facilitate decontamination and ultimate decommissioning in accordance with DOE Order 6430.1A, Section 1300 and DOE Order 5820.2A, Chapter 5. 
WHC-SD-WM-FRD-021 REV. 1

\section{APPENDIX B}

\section{EXAMPLE RISK-BASED LEAKAGE THRESHOLDS FOR}

HANFORD SITE SINGLE-SHELL TANKS 
WHC-SD-WM-FRD-021 REV. 1

This page intentionally left blank. 


\section{B.1.0 INTRODUCTION}

This appendix provides an example method for estimating preliminary leakage threshold values (LTVs) for Hanford Site single-shell tanks (SSTs) based on carcinogenic and toxicological risk contributions. Other approaches or models could be developed. An LTV is a risk-based quantity of leakage calculated for each tank, that equates to either an assumed allowable level of cancer risk or an assumed allowable hazard quotient. Risk is based on transport modeling of potential contaminants of concern leaked from an SST closed with a surface barrier. The contaminants are modeled to leach to groundwater and migrate downgradient where a future resident would be exposed through ingestion of groundwater obtained from a well and through ingestion of vegetables irrigated with the groundwater. The LTVs provide a basis for evaluating SST leakage detection technologies for individual tanks. The values developed in this appendix are examples only; a more detailed evaluation of leakage and negotiation with the regulators will be required to establish final acceptance criteria.

The LTVs are not intended as specific limitations to leakage because higher amounts of leakage may be acceptable and may not endanger public health and safety, depending on factors such as the amount of residual waste in the tank following sluicing, the amount and type of waste in nearby waste sites, and the final tank closure criteria. The LTVs serve as leakage limit guidelines that may be used during the formulation of operations retrieval and response plans. As such, an initial LTV near zero (or at least below the leak detection limit) does not mean that the tank waste cannot or should not be retrieved using hydraulic sluicing. There are numerous parameters or criteria inherent in an LTV that can be changed or adjusted, for example, making extra efforts to leave less than $360 \mathrm{ft}^{3}$ of residual waste or allowing for lower leakage thresholds for other tanks within the tank farm.

There is now, and will continue to be, high uncertainty in the contribution to overall risk by new leakage during sluicing and other sources of contaminants of concern. The criteria and approach used in this appendix to calculate LTVs need to be refined and peer-reviewed before submittal to the regulators as proposed allowable leakage volume criteria. Alternative approaches to calculation of LTVs could include different points of compliance, different bases for allowable public and worker risk, different assumptions regarding probable tank farm closure, or different assumptions regarding the exposed individual or population. An example of an alternate approach is to base LTVs on the risk resulting to an individual that used the Columbia River as a source for drinking water. The LTVs that would result from such a scenario may be less restrictive than those provided in this appendix.

\section{B.2.0 ANALYTICAL APPROACH}

Conceptually, the LTV represents the maximum quantity of waste that could be leaked during retrieval while maintaining overall risk below an accepted threshold. Additional 
contributors to the overall risk include risk from past SST leaks, risks associated with any residual waste that would be left in the SSTs after retrieval and closure, and risks associated with other contaminant sources such as releases from nearby ponds, cribs, and trenches. It should be noted that no attempt was made in this study to include risks associated with releases from ponds, cribs, or trenches. The methodology used in this appendix to determine the LTV is described below. A full description of the methods and assumptions used to calculate the LTVs are included in the remainder of this section.

1. The suite of carcinogenic and toxic constituents of concern (COCs) was established for the SSTs based on a risk approach described in Treat et al. (1995). The risk per unit mass [A] (specific risk index) of each COC released to the environment was defined in Appendix $C$ to the previous revision of this report (Revision 0 ). The specific risk index is based on the baseline case of retrieving SST waste using traditional past-practice sluicing and landfill closure of the SST farms. For this case, as described in Treat et al. (1995) it was assumed that closure would consist of structurally stabilizing the tanks (residual remaining in place) followed by installation of a protective surface barrier that limits recharge to $0.05 \mathrm{~cm} / \mathrm{yr}$ (Section B.2.1).

2. An overall maximum allowable risk $[B]$ for both carcinogenic and noncarcinogenic risks associated with a closed tank farm was assumed. The maximum allowable risks are assumed to be the same for each tank farm (Section B.2.2).

3. The potential for overlapping SST leakage plumes from adjacent tank farms was assessed and tank farms with overlapping plumes were consolidated into tank farm groups (Section B.2.3).

4. On a tank farm by tank farm basis, an estimate was made of the mass of COCs released to the environment from past SST leaks and the mass of COCs that eventually would be released as a result of residual waste left in the SST following retrieval. These COC masses, by tank farm group, were multiplied by the risk per unit mass, yielding the cumulative risks associated with past SST leaks $[C]$ (Section B.2.4) and residual waste [D] (Section B.2.5).

5. The risks from past SST leaks and residual waste were subtracted from the assumed overall maximum allowable risk. This difference was identified as the maximum acceptable risk from new SST leakage $[E]$, on a tank farm group basis (Section B.2.6).

$$
E=B-(C+D)
$$

6. An estimate was made, following logic developed in Treat et al. (1995) and best engineering judgement, of the number of tanks $[F]$ that would leak during retrieval, in each tank farm (Section B.2.7). 
7. The concentrations of COCs $[H]$ (mass per unit volume) in the liquid phase of each tank were determined from sample data. It was assumed that new SST leaks would have concentrations equal to these dissolved concentrations (Section B.2.8).

8. On an individual tank basis, the risk for each $\mathrm{COC}$ per unit volume of liquid waste was calculated as the product of the dissolved concentration of $\mathrm{COC}$ times the risk per unit mass for that COC. The risk for each of the COCs was summed to give the cumulative risk per unit volume [I] (Section B.2.8).

$$
I=\Sigma(H * A)
$$

9. The maximum allowable risk per tank [ $G]$ was determined by dividing each tank farm group's specific risk from new leakage by the number of tanks assumed to leak during retrieval (Section B.2.9).

$$
G=E / F
$$

10. The leakage threshold value [LTV] for each individual tank was calculated as quotient of the leakage risk allowable per tank divided by the risk per unit volume of leakage (Section B.2.9).

$$
L T V=G / I
$$

\section{B.2.1 CONSTITUENTS OF CONCERN}

The waste inventory in Hanford Site SSTs includes more than 150 chemicals and radionuclides; however, a relatively small subset of the constituents are considered COCs-i.e., they are sufficiently toxic and mobile and present in quantities large enough to produce risks to the public via groundwater that would exceed the U.S. Environmental Protection Agency's general acceptance thresholds. The COCs developed for Hanford Site SSTs are shown in Table B-1 and were based on data from Single-Shell Tank Constituent Rankings for Use in Preparing Waste Characterization Plans (Droppo et al. 1991). This study evaluated risks based on leakage and transport to groundwater and human health exposure through ingestion and use of groundwater for irrigation. Constituents that resulted in a potential health risk greater than $1 \times 10^{-4}$ for carcinogens and a hazard index (HI) greater than 1.0 for toxicants were determined to be COCs. The transport model used in Droppo et al. (1991) was based on an assumed recharge rate of $10 \mathrm{~cm} / \mathrm{yr}$ (4 in/yr), which is conservative relative to the assumed performance of closed tank farms.

The specific risk index values shown in Table B-1 were derived using the model and approach documented in the Feasibility Study of Tank Leakage Mitigation Using Subsurface Barriers (Treat et al. 1995). This study analyzed the performance of the Tank Waste Remediation System (TWRS) baseline alternative in terms of public risk exposure via 
Table B-1. Constituents of Concern and Risk Indexes for Hanford Site Single-Shell Tanks.

\begin{tabular}{|c|c|c|c|c|}
\hline Constituent & $\begin{array}{c}\text { Specific Activity } \\
(\mathrm{Bq} / \mathrm{g})\end{array}$ & $\begin{array}{c}\text { Specific Risk } \\
\text { Index (R/g or } \\
\text { HI/g) }\end{array}$ & $\begin{array}{c}\text { Maximum } \\
\text { Assumed } \\
\text { Solubility }(\mathrm{g} / \mathrm{L})\end{array}$ & $\begin{array}{c}\text { Solubility Basis } \\
\text { (Note 3) }\end{array}$ \\
\hline \multicolumn{5}{|l|}{ Radionuclides } \\
\hline Carbon, C14 & $1.65 \mathrm{E}+11$ & $1.36 \mathrm{E}-06$ & $6.73 \mathrm{E}-07$ & sw \\
\hline Iodine, I129 & $6.44 \mathrm{E}+06$ & $2.52 \mathrm{E}-13$ & $1.72 \mathrm{E}-03$ & sw \\
\hline Technetium, Tc99 & $6.29 \mathrm{E}+08$ & $3.58 \mathrm{E}-09$ & $2.70 \mathrm{E}-02$ & $\mathrm{sn} / \mathrm{BY}-102$ \\
\hline Uranium, U233 & $3.57 \mathrm{E}+08$ & Note 1 & & \\
\hline Uranium, U234 & $2.32 \mathrm{E}+08$ & Note 1 & & \\
\hline Uranium, U235 & $7.99 \mathrm{E}+04$ & Note 1 & & \\
\hline Uranium, U238 & $1.24 \mathrm{E}+04$ & $3.29 \mathrm{E}-15$ & $3.84 E+02$ & $\mathrm{sn} / \mathrm{BX}-112$ \\
\hline \multicolumn{5}{|c|}{ Chemicals/Elements } \\
\hline Arsenic, As & NA & $2.76 \mathrm{E}-15$ & $3.45 \mathrm{E}-01$ & $\mathrm{dr}$ \\
\hline Beryllium, Be & NA & Note 2 & & \\
\hline Cyanide, $\mathrm{CN}$ & NA & $5.32 \mathrm{E}-08$ & $9.13 \mathrm{E}-02$ & $\mathrm{sn} / \mathrm{C}-102$ \\
\hline Chromium, $\mathrm{Cr}$ & NA & $1.18 \mathrm{E}-16$ & $1.00 \mathrm{E}+01$ & sw \\
\hline EDTA & NA & $5.02 \mathrm{E}-07$ & $2.81 \mathrm{E}-02$ & $\mathrm{dr}$ \\
\hline Fluoride, $\mathrm{F}$ & NA & $7.52 \mathrm{E}-10$ & $6.02 \mathrm{E}+00$ & $\mathrm{sn} / \mathrm{T}-110$ \\
\hline Mercury, $\mathrm{Hg}$ & $\mathrm{NA}$ & $1.30 \mathrm{E}-06$ & $3.20 \mathrm{E}-01$ & $\mathrm{dr}$ \\
\hline Sodium, Na & NA & $2.75 \mathrm{E}-13$ & $3.56 \mathrm{E}+02$ & $\mathrm{dl} / \mathrm{SX}-104$ \\
\hline Nitrite, $\mathrm{NO}_{2}$ & $\mathrm{NA}$ & $9.09 \mathrm{E}-10$ & $1.41 \mathrm{E}+02$ & $\mathrm{dl} / \mathrm{C}-109$ \\
\hline Nitrate, $\mathrm{NO}_{3}$ & $\mathrm{NA}$ & $7.69 \mathrm{E}-10$ & $4.09 \mathrm{E}+02$ & $\mathrm{~d} l / \mathrm{SX}-104$ \\
\hline Antimony, Sb & NA & $9.26 \mathrm{E}-08$ & $8.46 \mathrm{E}+00$ & $\mathrm{dr}$ \\
\hline Sulfate, $\mathrm{SO}_{4}$ & $\mathrm{NA}$ & $1.81 \mathrm{E}-12$ & $9.70 \mathrm{E}+00$ & $\mathrm{sn} / \mathrm{A}-102$ \\
\hline Vanadium, $\mathrm{V}$ & NA & $4.29 \mathrm{E}-09$ & $8.46 \mathrm{E}+00$ & $\mathrm{dr}$ \\
\hline
\end{tabular}

Notes:

1 The uranium isotopes were combined in the analysis of U238.

2 Beryllium was not analyzed since no current reports indicate its presence in any tank.

3 Symbols for the solubility basis are as follows:

$\mathbf{d l} / \mathbf{x}-\mathbf{x x x}$ - solubility based on drainable liquid sample from tank $x-\mathbf{x x x}$

$\mathrm{sn} / \mathrm{x}-\mathrm{xxx}$ - solubility based on supernate sample from tank $\mathrm{x}-\mathrm{xxx}$

sw - solubility based on data from Serne and Wood (1990)

$\mathrm{dr}$ - solubility based on data from Droppo et al. (1991) 
groundwater. The specific risk index values indicate the potential peak risk to a maximally exposed individual (MEI) per gram of material released, assuming a 70-year MEI lifetime and distribution coefficients $\left(\mathrm{K}_{\mathrm{d}}\right)$ of zero for each of the COCs. The relative magnitude of human health risks were evaluated based on assumed exposure to contaminated groundwater at the point of interest immediately downgradient of the tank farm. Pathways by which contaminants were assumed to reach and expose a hypothetical individual at that location, based on the standards used at the Hanford Site, include:

- Drinking water ingestion

- Crop ingestion from farmland contaminated by irrigation from groundwater

- Animal product ingestion from animals fed contaminated forage and groundwater.

The exposure analyses were based on an assumed 70-year lifetime exposure to constant groundwater contaminant concentrations, which are based on the average value over the 70-year period. Relative health risks were evaluated separately for exposure to carcinogenic and noncarcinogenic materials. Carcinogenic health risk was expressed as the incremental lifetime cancer risk to an individual from exposure to radioactive contaminants and nonradioactive carcinogenic chemicals. The relative impact on an individual from exposure to noncarcinogenic toxic chemicals was evaluated by calculating the HI ratio of the calculated exposure level (dose) to a toxic threshold reference dose. An HI less than 1 is taken to indicate the probable absence of detrimental toxic effects.

It should be noted that the time at which such a peak would occur would be approximately 19,000 years following closure of the tank farms. The model results used to determine the risk factors (Treat et al. 1995) were based on a hypothetical tank farm consisting of twelve tanks in a three by four array, with average SST waste composition and geological features typical of the Hanford Site 200 East and 200 West Areas. Accordingly, the risk factors may be conservative or nonconservative under specific geologic and inventory conditions. Also, the risk factors do not take into account the potential superposition of contaminant plumes migrating from other sources such as cribs, ponds, and burial trenches. The specific risk index is determined by division of the relative health risk calculated in Treat et al. (1995) by the mass of constituents that produced the risk.

\section{B.2.2 MAXIMUM ALLOWABLE RISK THRESHOLDS}

The allowable risk thresholds were assumed to be $1 \times 10^{-4}$ for carcinogens and 1.0 for toxicants. The previous revision of this document (Revision 0 ) began with the thresholds as stated, then reduced them by two orders of magnitude to compensate for unknown or unaccounted sources of risk. This report addresses many of the sources of risk excluded from the Revision 0 report (e.g., residual waste, overlapping leakage plumes from adjacent tank farms). In addition, there are other sources, such as discharges to cribs or trenches, 
that are not included in this analysis. A conservative method of accounting for the risk contribution of sources that are not included in this analysis is to reduce the assumed risk thresholds by one order of magnitude to $1 \times 10^{-5}$ for carcinogens and 0.1 for toxicants. The impacts of using this assumption are discussed in the Section B.3.0.

\section{B.2.3 TANK FARMS GROUPS}

A worst-case risk scenario is a well drilled for drinking water and irrigation purposes downgradient of multiple tank farms where the contamination plumes from the tank farms would overlap. Water withdrawn from this hypothetical well would experience the combined impacts from the overlapping plumes. Tank farms that would create overlapping contamination plumes based on the relative locations of the tank farms and the direction of groundwater flow are the B, BX, and BY Tank Farms. These three tank farms were considered as a single tank farm group and each of the other tank farms was considered to be its own group. Maps of the tank farms and future groundwater flow directions in the 200 West and 200 East Areas are provided as Figures B-1 and B-2.

\section{B.2.4 RISK CONTRIBUTION FROM PAST LEAKAGE}

The risk contributions for past leakage from each tank were determined by multiplying the past leakage volume given in Table I-1 of the Tank Farm Surveillance and Waste Status Summary Report for October 1995 (Hanlon 1996) by the tank-dependent risk per volume and assumed concentrations (equal to concentrations of current interstitial liquor). If no volume of past leakage was given in Hanlon (1996) (i.e., a leak of unknown magnitude), the average volume of past leaks was assumed $(8,000$ gal [Hanlon 1996]). The risk contributions were then summed within a tank farm group to obtain a single risk contribution for each tank farm group.

\section{B.2.5 RISK CONTRIBUTION FROM RESIDUAL WASTE}

The risk contribution from residual waste is the risk resulting from waste left in the tank and tank concrete after completing retrieval operations. The amount of residue waste assumed was based on the Tri-Party Agreement Milestone M-45-00, which states:

Closure will follow retrieval of as much tank waste as technically possible, with tank waste residues not to exceed 360 cubic feet (cu. ft.) in each of the 100 series tanks, $30 \mathrm{cu}$. ft. in each of the 200 series tanks, or the limit of waste retrieval technology capability, whichever is less.

The risk contribution from residual waste was based on the maximum allowed residual waste volumes (360 or $30 \mathrm{ft}^{3}$ ) and the tank-dependent risks per volume of waste in each tank. The 


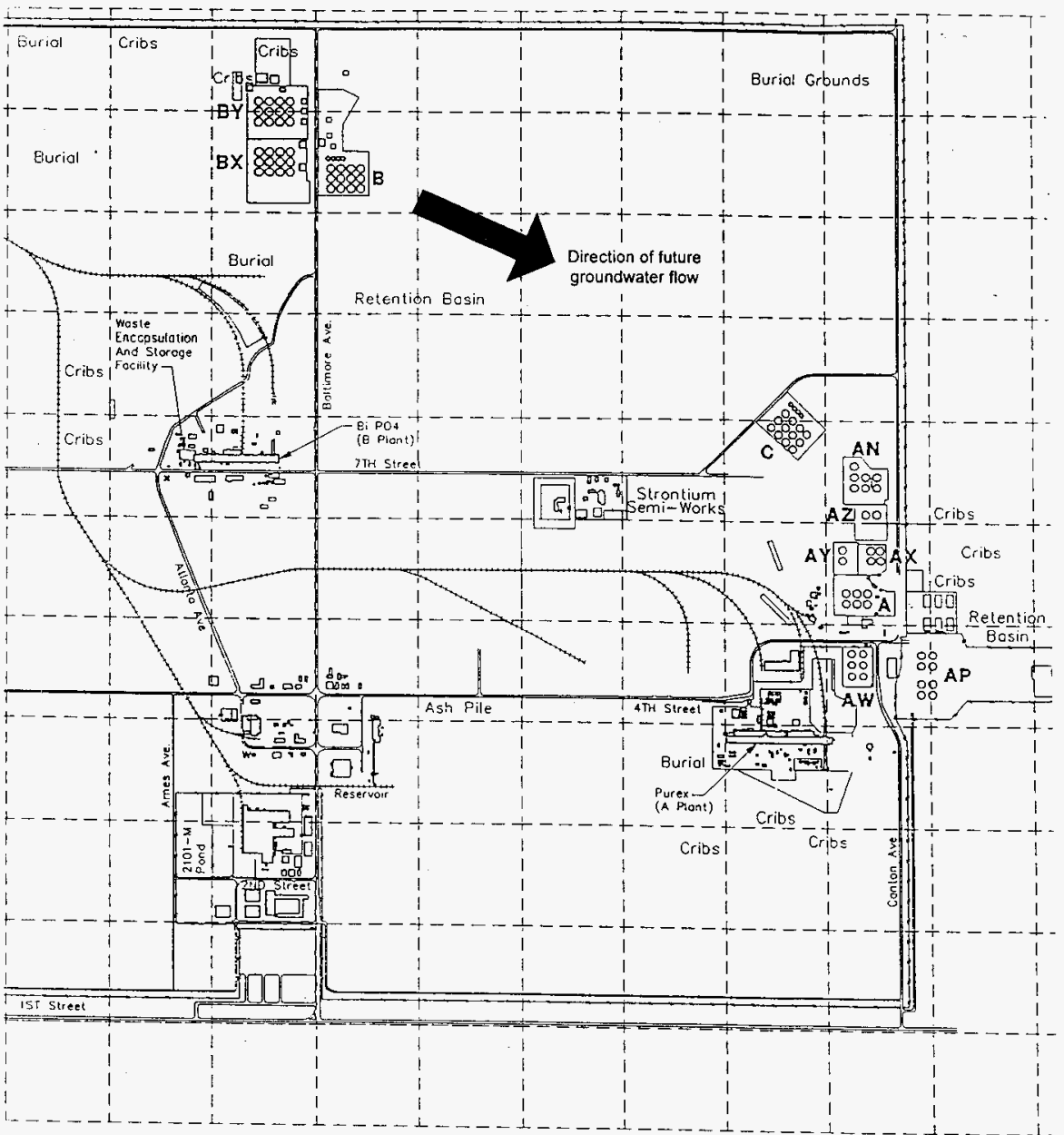

Figure B-1. 200 East Area Map Showing Tank Farms and Future Groundwater Flow Direction. 


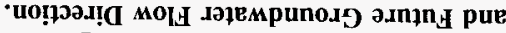

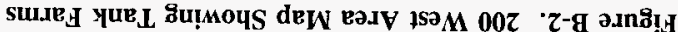

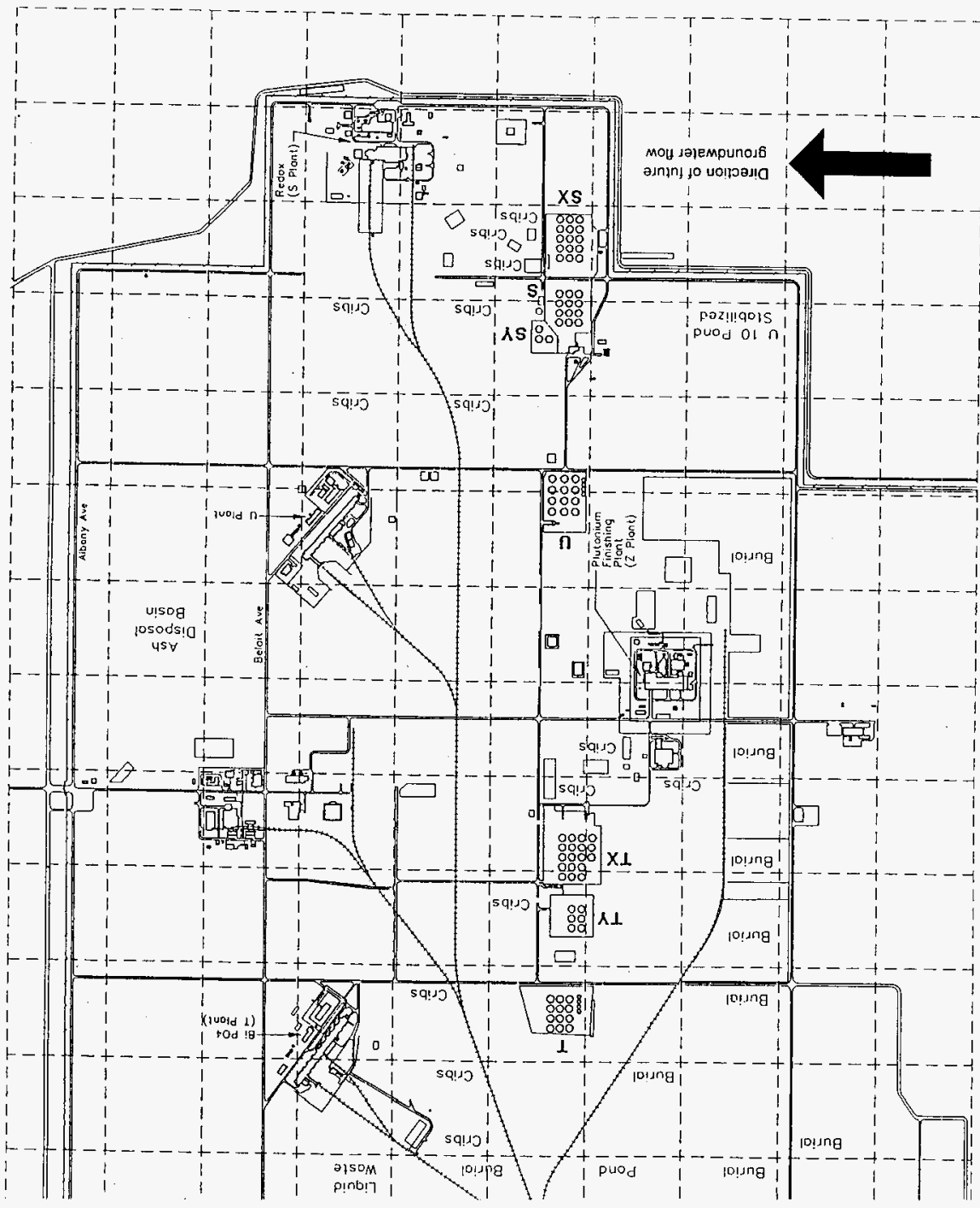


risk contributions for each tank were summed within a tank farm group to obtain a risk contribution for residual waste in each tank farm group.

In the case of three tank farm groups, AX Tank Farm, B Tank Farm Group (B, BX, BY), and SX Tank Farm, the risks associated with the residual waste exceeded one or both of the total allowable risk thresholds for the entire tank farm groupings. For these cases, the data were examined to isolate the tanks that have significant risks associated with the residual waste. The tanks that were determined to have excessive residual waste risks were tanks AX-104, B-111, BX-104, BX-105, BX-106, and SX-115. For several of these tanks, a detailed review of inventory data would likely find errors in the ${ }^{99} \mathrm{Tc}$ data (the risk driver).

For these special cases in which the residual waste risk exceeded the allowable risk threshold, it was assumed that a retrieval method other than past-practice sluicing may be required to reduce the volume of residual waste. It was assumed that the alternate retrieval method would be capable of reducing the residual waste to 1/10th that allowed in Tri-Party Agreement Milestone M-45-00 (36 or $3 \mathrm{ft}^{3}$ ). This is equivalent to a waste retrieval of $99.9 \%$, which was assumed in Treat et al. (1995) for the performance of robotic sluicing.

The tank inventories of the COCs were used to calculate the residual waste risks. The tank inventories of COCs were based on TRAC data or sample information contained in Van Vleet (1993). In cases where sample information indicated a larger inventory than estimated by TRAC, the sample information was conservatively used as the basis.

\section{B.2.6 RISK CONTRIBUTION FROM RETRIEVAL LEAKAGE}

The assumed allowable risk contribution from retrieval leakage is the difference between the assumed overall risk threshold values for each tank farm group and the sum of other risk contributions. The overall risk threshold values, as described in Section B.2.2, are $1 \times 10^{-4}$ for carcinogens and 1.0 for toxicants. Other risk contributions are limited in this report to past leakage risks and residual waste risks. Therefore, for each tank farm group, the carcinogenic risk contribution for retrieval leakage is equal to $1 \times 10^{-4}$ less the sum of the tank-farm-dependent risk contribution from past leakage and the tank-farm-dependent risk contribution from residual waste.

\section{B.2.7 RETRIEVAL LEAKS}

The number of new leaks assumed to occur during retrieval activities was based on data for past leaks and best engineering judgement. A total of 67 tanks have leaked in the past (Hanlon 1996). It is assumed that $60 \%$ of these tanks ( 40 tanks) will leak again during retrieval and $30 \%$ of the previously nonleaking tanks ( 24 tanks) will develop leaks during retrieval resulting in 64 tanks leaking during retrieval. This assumption follows that developed in Treat et al. (1995). The new leaks assumed for any given tank farm may not 
WHC-SD-WM-FRD-021 REV. 1

Table B-2. Past Tank Leakage and New Leakage Expected During Tank Retrieval.

\begin{tabular}{|l|c|c|c|c|c|}
\hline Tank Farm & $\begin{array}{c}\text { No. of } \\
\text { Tanks }\end{array}$ & $\begin{array}{c}\text { No. of Past } \\
\text { Leaks }\end{array}$ & $\begin{array}{c}\text { Expected } \\
\text { Leaks from } \\
\text { Sound Tanks }\end{array}$ & $\begin{array}{c}\text { Expected Leaks } \\
\text { from Non-Sound } \\
\text { Tanks }\end{array}$ & $\begin{array}{c}\text { Total Expected } \\
\text { Retrieval } \\
\text { Leaks }\end{array}$ \\
\hline A & 6 & 3 & 1 & 2 & 3 \\
\hline AX & 4 & 2 & 1 & 1 & 2 \\
\hline B & 16 & 10 & 2 & 6 & 8 \\
\hline BX & 12 & 5 & 2 & 3 & 5 \\
\hline BY & 12 & 5 & 2 & 3 & 5 \\
\hline B+BX+BY & 40 & 20 & 6 & 12 & 18 \\
\hline C & 16 & 7 & 3 & 4 & 7 \\
\hline S & 12 & 1 & 3 & 1 & 4 \\
\hline SX & 15 & 10 & 1 & 6 & 7 \\
\hline T & 16 & 7 & 3 & 4 & 7 \\
\hline TX & 18 & 8 & 3 & 5 & 8 \\
\hline TY & 6 & 5 & 0 & 3 & 3 \\
\hline U & 16 & 4 & 3 & 2 & 5 \\
\hline TOTALS & 149 & 67 & 24 & 40 & 64 \\
\hline
\end{tabular}


match the number of past leaks from that given farm. The past leak data and the estimate for retrieval leaks are provided in Table B-2.

\section{B.2.8 LEAKAGE VOLUME RISKS}

The risks for each $\mathrm{COC}$ in leakage from a given tank were calculated by multiplying the dissolved concentration of the COC, expressed as mass per unit volume, by the specific risk index for the COC, expressed as risk per mass, to obtain a risk per unit volume. The specific risk indexes for each COC are listed in Table B-1.

The dissolved concentrations for each COC were based on tank-specific liquid sample data (supernate or drainable liquid) as presented in Radionuclides and Chemical Inventories for the Single-Shell Tanks (Van Vleet 1993), Hanford Waste Form Releases and Sediment Interactions (Serne and Wood 1990), or Single-Shell Tank Constituent Rankings for Use in Preparing Waste Characterization Plans (Droppo et al. 1991). If no sample data were available, the solubility was assumed to be the ratio of the inventory of the given COC to the total waste volume of the tank, with the concentration limited to the maximum solubility observed in any liquid SST waste sample ever analyzed.

A tank-dependent leakage-risk-per-volume factor was calculated for each tank by summing the COC risk-per-volume factors for all COCs present in the tank.

\section{B.2.9 LEAKAGE THRESHOLD VALUES}

The LTV for each tank was determined by evenly apportioning the tank farm-dependent risk contribution from retrieval leakage among the estimated number of leaks in the tank farm group and then converting the risk values to volumes using leakage-risk-per-volume factors for each tank. The allowable volume per leak assigned to each tank within a tank farm group is the tank-dependent LTV, which represents the maximum allowable volume that may be leaked without exceeding the established overall risk thresholds for a tank farm group.

\section{B.3.0 RESULTS AND CONCLUSIONS}

Table B-3 provides a summary of the LTVs calculated for each tank using the example method described in Section 2. Two LTVs were calculated for each tank; the carcinogenicbased LTV and the toxicant-based LTV. These LTVS were compared for each tank and the lowest value was selected as the limiting tank LTV and presented in Table B-3. Figure B-3 graphically represents the limiting tank LTVs. These LTVs are dependent on many assumptions regarding existing tank inventories, retrieval effectiveness, leakage concentrations, closure design, and other factors. Each of these assumptions have a range of reasonable values that will affect the calculated LTVs for future retrieval cases. 
WHC-SD-WM-FRD-021 REV. 1

Table B-3. Threshold Leakage Values for Each Tank. (sheet 1 of 3)

\begin{tabular}{|c|c|c|c|c|c|}
\hline Tank & Volume & Cancer LTV & Toxicant LT & LTV & Limiting \\
\hline & (gal) & (gal) & (gal) & (gal) & Factor \\
\hline$A-101$ & $9.53 E+05$ & $1.58 E+08$ & $4.62 \mathrm{E}+04$ & $4.62 \mathrm{E}+04$ & Toxicant \\
\hline$A-102$ & $4.10 E+04$ & $3.84 \mathrm{E}+04$ & $1.04 \mathrm{E}+05$ & $3.84 \mathrm{E}+04$ & Cancer \\
\hline A-103 & $3.70 \mathrm{E}+05$ & $6.62 \mathrm{E}+04$ & $7.06 \overline{\mathrm{E}+04}$ & $6.62 E+04$ & Cancer \\
\hline A-104 & $2.80 E+04$ & $2,75 \mathrm{E}+06$ & $3.82 \mathrm{E}+04$ & $3.82 \mathrm{E}+04$ & Toxicant \\
\hline$A-10 \overline{5}$ & $1.90 E+04$ & $1.00 E+05$ & $1.54 E+05$ & $1.00 E+05$ & Cancer \\
\hline$A-106$ & $1.25 \mathrm{E}+05$ & $9.42 \mathrm{E}+04$ & $8.02 \mathrm{E}+04$ & $8.02 E+04$ & Toxicant \\
\hline$A \bar{X}-101$ & $7.48 E+05$ & $8.85 E+08$ & $1.81 E+05$ & $1.81 \mathrm{E}+05$ & Toxicant \\
\hline AX-102 & $3.90 \mathrm{E}+04$ & $4.64 \mathrm{E}+09$ & $1.97 \overline{E+05}$ & $1.97 \mathrm{E}+05$ & Toxicant \\
\hline$A \bar{X}-103$ & 1.12E+05 & $2.15 \mathrm{E}+06$ & $2.23 \mathrm{E}+05$ & $2.23 E+05$ & Toxicant \\
\hline$A X-104$ & $7.00 \mathrm{E}+03$ & $1.29 E+05$ & $6.19 E+04$ & $6.19 E+04$ & Toxicant \\
\hline B-10i & $1.13 E+05$ & $3.93 E+02$ & $1.81 \mathrm{E}+04$ & $3.93 E+02$ & Cancer \\
\hline $3-102$ & $3.20 \mathrm{E}+04$ & 1.67E+02 & $5.52 E+04$ & $1.67 \mathrm{E}+02$ & Cancer \\
\hline B-103 & $5.90 E+04$ & $7.24 E+01$ & $7.23 \bar{E}+04$ & $7.24 \mathrm{E}+01$ & Cancer \\
\hline$\overline{B-104}$ & $3.71 \mathrm{E}+05$ & $1.09 E+03$ & $1.71 \mathrm{E}+05$ & $1.09 E+03$ & Cancer \\
\hline B-105 & $3.06 \mathrm{E}+05$ & $1.55 \mathrm{E}+02$ & $4.34 E+04$ & $1.55 \mathrm{E}+02$ & Cancer \\
\hline B-106 & $1.17 \mathrm{E}+05$ & $6.10 \mathrm{E}+02$ & $3.77 E+04$ & $6.10 E+02$ & Cancer \\
\hline B- 107 & $1.65 \mathrm{E}+05$ & $9.80 \mathrm{E}+01$ & $1.74 E+04$ & $9.80 \mathrm{E}+01$ & Cancer \\
\hline B-108 & $9.40 E+04$ & $2.26 \mathrm{E}+01$ & $1.60 \mathrm{E}+04$ & $2.26 \mathrm{E}+0 \mathrm{~T}$ & Cancer \\
\hline B-109 & $1.27 E+05$ & $8.71 \mathrm{E}+01$ & $3.42 \mathrm{E}+04$ & $8.71 \mathrm{E}+01$ & Cancer \\
\hline $\mathrm{B}-110$ & $2.46 \mathrm{E}+05$ & $6.20 E+00$ & $2.22 \mathrm{E}+04$ & $6.20 \mathrm{E}+00$ & Cancer \\
\hline B-111 & $2.37 \mathrm{E}+05$ & $4.34 \mathrm{E}+00$ & $1.61 \mathrm{E}+04$ & $4.34 \mathrm{E}+00$ & Cancer \\
\hline $\bar{B}-112$ & $3.30 \mathrm{E}+04$ & $4.34 \mathrm{E}+0 \mathrm{C}$ & $1.27 E+04$ & $4.34 \mathrm{E}+00$ & Cancer \\
\hline $\mathrm{B}-20$ & $2.90 E+04$ & Not Availabi & $1.26 \bar{E}+04$ & $1.26 \mathrm{E}+04$ & Toxicant \\
\hline$B-202$ & $2.70 E+04$ & $1.60 E+02$ & $3,73 E+04$ & $1.60 E+02$ & Cancer \\
\hline $\mathrm{B}-203$ & $5.10 E+04$ & $1.12 \mathrm{E}+05$ & $9.50 \mathrm{E}+03$ & $9.50 \mathrm{E}+03$ & Toxicant \\
\hline B-204 & $5.00 \mathrm{E}+04$ & $2.11 E+06$ & $8.23 E+04$ & $8.23 E+C 4$ & Toxicant \\
\hline $6 \times-101$ & $4.30 E+04$ & $3.87 E+02$ & $2.79 E+04$ & $3.8 \bar{E}+02$ & Cancer \\
\hline $\mathrm{BX}-102$ & $9.60 \mathrm{E}+04$ & $4.34 \mathrm{E}+00$ & $2.47 \mathrm{E}+\mathrm{O} 4$ & $4.34 \mathrm{E}+00$ & Cancer \\
\hline $8 X-103$ & $6.60 \mathrm{E}+04$ & $4.62 \mathrm{E}+02$ & $1.65 E+05$ & $4.62 \mathrm{E}+02$ & Cancer \\
\hline $\mathrm{BX}-104$ & $9.90 \mathrm{E}+04$ & $1.68 \mathrm{E}+01$ & $3.23 E+04$ & $1.68 \mathrm{E}+01$ & Cancer \\
\hline$B \times-105$ & $5.10 \mathrm{E}+04$ & $1.83 \mathrm{E}+01$ & $3.89 \mathrm{E}+04$ & $1.83 \bar{E}+01$ & Cancer \\
\hline$B X-106$ & $4.60 \mathrm{E}+04$ & $4.34 E+00$ & $2.70 E+04$ & $4.34 E+00$ & Cancer \\
\hline$B X-107$ & $3.45 E+05$ & $4.80 \mathrm{E}+02$ & $3.59 \bar{E}+04$ & $4.80 \bar{E}+02$ & Cancer \\
\hline$B X-108$ & $2.60 E+04$ & $8.91 \mathrm{E}+02$ & $3.62 \mathrm{E}+05$ & $8.91 \mathrm{E}+02$ & Cancer \\
\hline BX-109 & $193 \mathrm{BE}+05$ & $2.03 E+02$ & $2.19 E+04$ & $2.03 E+02$ & Cancer \\
\hline$B X-110$ & $1.98 \mathrm{E}+05$ & $5.01 E+00$ & $2.07 E+04$ & $5.01 \mathrm{E}+0 \overline{0}$ & Cancer \\
\hline$B X-111$ & $2.11 \mathrm{E}+05$ & $5.34 E+00$ & $3.10 E+04$ & $5.34 E+00$ & Cancer \\
\hline$B X-112$ & $1.65 \bar{E}+05$ & $1.48 E+02$ & $4.6 \overline{1} \overline{E+04}$ & $1.48 E+02$ & Cancer \\
\hline$\overline{B Y}-101$ & $3.67 \mathrm{E}+05$ & $6.79 E+00$ & $1.31 E+04$ & $6.79 \overline{\mathrm{E}}+0 \mathrm{D}$ & Cancer \\
\hline BY-102 & $3.44 E+05$ & $4.34 E+00$ & $3.74 E+04$ & $4.34 \mathrm{E}+0 \overline{0}$ & Cancer \\
\hline BY -103 & $4.00 E+05$ & $1.66 \mathrm{E}+01$ & $3.93 E+04$ & $1.66 \mathrm{E}+01$ & Cancer \\
\hline$B Y-104$ & $4.06 \mathrm{E}+05$ & $7.45 E+00$ & $1.32 E+04$ & $7.45 \mathrm{E}+00$ & Cancer \\
\hline BY-105 & $5.03 E+05$ & $5.78 E+01$ & $2.61 E+04$ & $5.78 \mathrm{E}+01$ & Cancer \\
\hline$B Y-10 \overline{6}$ & $6.42 E+05$ & $2.20 \mathrm{E}+01$ & $3.75 E+04$ & $2.20 \mathrm{E}+01$ & Cancer \\
\hline$B Y-107$ & $2.66 \bar{E}+05$ & $9.89 E+00$ & $1.55 \mathrm{E}+04$ & $9.89 E+00$ & Cancer \\
\hline BY.108 & $2.28 \mathrm{E}+05$ & $8.51 \mathrm{E}+00$ & $1.38 \mathrm{E}+04$ & $8.51 \mathrm{E}+00$ & Cancer \\
\hline$\overline{\mathrm{BY}}-109$ & $4.23 \mathrm{E}+05$ & 2.13E+01 & $4.86 E+04$ & $2.13 \mathrm{E}+\mathrm{C} 1$ & Cancer \\
\hline BY-110 & $3.96 \mathrm{E}+05$ & $7.32 E+00$ & $1.34 E+04$ & $7.32 \mathrm{E}+00$ & Cancer \\
\hline$B Y-111$ & $4.59 \mathrm{E}+\overline{05}$ & $8.46 \mathrm{E}+\infty 0$ & $1.39 E+04$ & $8.46 E+00$ & Cancer \\
\hline$B Y-112$ & $2.91 E+05$ & $2.58 \mathrm{E}+01$ & $4.29 \mathrm{E}+04$ & $2.58 \mathrm{E}+0 \mathrm{~T}$ & Cancer \\
\hline $\mathrm{C}-101$ & $8.80 E+04$ & $9.75 E+04$ & $1.06 E+05$ & $9.75 E+04$ & Cancer \\
\hline $0-102$ & $4.23 \mathrm{E}+05$ & $9.34 E+05$ & $6.23 \mathrm{E}+05$ & $6.23 E+05$ & Toxicant \\
\hline $\mathrm{C}-103$ & $1.95 E+05$ & $3.70 E+05$ & $1.01 E+06$ & $3.70 \mathrm{E}+05$ & Cancer \\
\hline C-104 & $2,95 E+05$ & $5.20 E+05$ & $1.56 \mathrm{E}+05$ & $1.56 \bar{E}+05$ & Toxican: \\
\hline C-105 & $1.35 E+05$ & $5.91 E+04$ & $4.47 \mathrm{E}+04$ & $4 . \overline{47 \bar{E}+04}$ & Toxicant \\
\hline$\overline{C-106}$ & $2.29 \mathrm{E}+05$ & $1.09 E+05$ & $6 . \overline{17 E+04}$ & $6.17 E+04$ & Toxicant \\
\hline$C .10 \overline{7}$ & $2.75 E+05$ & $1.81 E+05$ & $3.53 E+05$ & $1.81 \mathrm{E}+05$ & Cancer \\
\hline $\mathrm{C}-10 \overline{8}$ & $6.60 \mathrm{E}+04$ & $8.09 \mathrm{E}+06$ & $4.56 E+05$ & $4.56 \overline{6}+05$ & Toxicant: \\
\hline
\end{tabular}


WHC-SD-WM-FRD-021 REV. 1

Table B-3. Threshold Leakage Values for Each Tank. (sheet 2 of 3)

\begin{tabular}{|c|c|c|c|c|c|}
\hline Tarik & Volume & Cancer LTV & Toxicant LT & LTV & Limiting \\
\hline & (gäl) & (gal) & $(g a \mid)$ & (gal) & Factor \\
\hline C-109 & $6.60 \mathrm{E}+04$ & $1.85 E+06$ & $2.01 E+05$ & $2.01 E+05$ & Toxicant \\
\hline$\overline{\mathrm{C}-110}$ & $1.87 E+05$ & 2.21E+05 & $3.16 \mathrm{E}+05$ & $2.21 \mathrm{E}+05$ & Cancer \\
\hline$\overline{\mathrm{C}-111}$ & $5 . \overline{70} \mathrm{E}+04$ & $1 . \overline{68 E+06}$ & $3.39 E+05$ & $3.39 \mathrm{E}+05$ & Toxicant \\
\hline$\overline{C-112}$ & $1.04 E+05$ & $2.30 \mathrm{E}+06$ & $2.30 \mathrm{E}+05$ & $2.30 E+05$ & Toxicant \\
\hline C-201 & $2.00 E+03$ & $1.70 E+08$ & $2.36 \mathrm{E}+05$ & $2.36 E+05$ & Toxicant \\
\hline $\mathrm{C}-202$ & $1.00 E+03$ & $4.30 E+06$ & $1.99 \mathrm{E}+09$ & $4.30 \mathrm{E}+06$ & Cancer \\
\hline $\mathrm{C}-203$ & $5.00 \mathrm{E}+03$ & $2.15 E+08$ & $9.94 E+10$ & $2.15 \mathrm{E}+08$ & Cancer \\
\hline C-204 & $3.00 \mathrm{E}+03$ & $4.78 E+09$ & $2.84 E+06$ & $2.84 E+06$ & Toxicant \\
\hline S-101 & $4.27 \mathrm{E}+05$ & $2.24 \mathrm{E}+05$ & $1.43 E+05$ & $1.43 E+05$ & Toxicant \\
\hline S-102 & $5.49 \mathrm{E}+05$ & $2.51 E+10$ & $2.38 E+05$ & $2.38 \mathrm{E}+05$ & Toxicant \\
\hline S-103 & $2.46 \mathrm{E}+05$ & $1.62 \mathrm{E}+10$ & $5.92 \mathrm{E}+05$ & $5.92 E+05$ & Toxicant \\
\hline S.104 & 2.94E+05 & $5.33 E+05$ & $1.57 \mathrm{E}+05$ & $1.57 \overline{\mathrm{E}}+05$ & Toxicant \\
\hline S-105 & $4.56 E+05$ & 1.33E+06 & $1.71 \mathrm{E}+05$ & $1.74 E+05$ & Toxicant \\
\hline S-10 6 & $4 . \overline{79 E+05}$ & $7.73 E+05$ & $1.67 \mathrm{E}+05$ & $1.67 \mathrm{E}+0 \overline{5}$ & Toxicarit \\
\hline S-107 & $3.76 E+05$ & $8.62 E+07$ & $2.22 E+05$ & $2.22 E+05$ & Toxicant \\
\hline S-108 & $6.04 E+05$ & $3.13 \mathrm{E}+05$ & $2.54 E+05$ & $2.54 E+05$ & Toxicant \\
\hline $8-109$ & $5.06 \mathrm{E}+05$ & $9.13 E+04$ & $1.55 E+05$ & $9.13 E+04$ & Cancer \\
\hline S-110 & $3.90 \mathrm{E}+05$ & $1.03 E+05$ & $1.62 \mathrm{E}+05$ & $1.03 \mathrm{E}+05$ & Cancer \\
\hline S-111 & $5.96 E+05$ & $2.11 \mathrm{E}+05$ & $2.15 E+05$ & $2.11 E+05$ & Cancer \\
\hline S-112 & $5.23 E+05$ & $6.20 \mathrm{E}+04$ & $1.31 \mathrm{E}+05$ & $6.20 \mathrm{E}+04$ & Cancer \\
\hline $\bar{X}-101$ & $4.56 E+05$ & $8.04 E+05$ & $1.45 \mathrm{E}+05$ & $1.45 \mathrm{E}+05$ & Toxicant \\
\hline $5 x-102$ & $5.43 E+05$ & $1.67 E+07$ & $2.82 E+04$ & $2.82 E+04$ & Toxicant \\
\hline $5 X-103$ & $6.52 \mathrm{E}+05$ & $2.52 \mathrm{E}+04$ & $1.47 E+04$ & $1.47 \mathrm{E}+04$ & Toxicant \\
\hline $5 \times-104$ & $6.14 \mathrm{E}+05$ & $8.84 \mathrm{E}+04$ & $2.49 E+04$ & $2.49 E+04$ & Toxicant \\
\hline $5 X-105$ & $6.83 E+05$ & $4.23 E+04$ & $3.18 \mathrm{E}+04$ & $3.18 E+04$ & Toxicant \\
\hline $5 x-106$ & $5.36 \mathrm{E}+05$ & $7.75 E+04$ & $1.65 E+05$ & $7.75 \mathrm{E}+04$ & Cancer \\
\hline $5 x-107$ & $1.04 \mathrm{E}+05$ & $4.82 E+07$ & $8.58 \mathrm{E}+04$ & $8.58 \mathrm{E}+04$ & Toxicant \\
\hline $5 \bar{X}-108$ & $8 . \overline{10 E+04}$ & $3.7 \overline{\mathrm{E}+07}$ & $3.44 E+04$ & $3.44 \mathrm{E}+04$ & Toxicant \\
\hline $5 x-109$ & $2.50 \mathrm{E}+05$ & $2.13 \mathrm{E}+08$ & $3.44 E+04$ & $3.44 E+04$ & Toxicant \\
\hline $5 X-110$ & $6.20 \mathrm{E}+04$ & $2.90 \mathrm{E}+07$ & $3.44 \mathrm{E}+04$ & $3.44 E+04$ & Toxicant \\
\hline$S x-111$ & $1.25 \mathrm{E}+05$ & $5.77 \mathrm{E}+07$ & $7.68 \mathrm{E}+04$ & $7.68 \mathrm{E}+04$ & Toxicant \\
\hline$S X-112$ & $9.20 \mathrm{E}+04$ & $3.04 E+06$ & $3.44 \mathrm{E}+04$ & $3 . \overline{44 E+04}$ & Toxicant \\
\hline$S X-113$ & $2.60 \mathrm{E}+04$ & $2.52 E+04$ & $3.44 \mathrm{E}+04$ & $2.52 \mathrm{E}+04$ & Cancer \\
\hline$\overline{S X-114}$ & $1.81 E+05$ & $5.62 \mathrm{E}+07$ & $3.44 \mathrm{E}+04$ & $3.4 \overline{\mathrm{E}+04}$ & Toxicant \\
\hline$S x-115$ & $1.20 \mathrm{E}+04$ & $2.52 E+04$ & $3.41 \mathrm{E}+04$ & $2.52 \mathrm{E}+04$ & Cancer \\
\hline$T-101$ & $1.02 \mathrm{E}+05$ & $1.57 E+05$ & 1.23E+05 & $1.23 \mathrm{E}+05$ & Toxicant \\
\hline$T-102$ & $3.20 \mathrm{E}+04$ & $1.38 \mathrm{E}+06$ & $2.29 \mathrm{E}+05$ & $2.29 \mathrm{E}+05$ & Toxicant \\
\hline $\mathrm{T}-103$ & $2.70 \mathrm{E}+04$ & $2.39 \mathrm{E}+05$ & $2.83 E+05$ & $2.39 E+05$ & Cancer \\
\hline$T-104$ & $445 \mathrm{E}+05$ & $8.89 E+06$ & $2,44 E+05$ & $2.44 \mathrm{E}+05$ & Toxicant \\
\hline$T-10 \overline{5}$ & $9.60 \mathrm{E}+04$ & $6.79 E+07$ & $4.11 \mathrm{E}+05$ & $4.11 \overline{E+05}$ & Toxicant \\
\hline$T-106$ & $2.10 \mathrm{E}+04$ & $3.54 \mathrm{E}+06$ & $9.07 E+04$ & $9.07 \bar{E}+04$ & Toxicant \\
\hline $\mathrm{T}-107$ & $1.80 E+05$ & $6.52 \mathrm{E}+08$ & $1.02 E+06$ & $1.02 \mathrm{E}+06$ & Toxicant \\
\hline$T-108$ & $4.40 E+04$ & $6.50 E+06$ & $3.70 \mathrm{E}+0 \overline{05}$ & $3.70 \mathrm{E}+05$ & Toxicant \\
\hline$T-10 \overline{9}$ & $5.80 \mathrm{E}+04$ & $1.78 E+06$ & $3.42 \mathrm{E}+05$ & $3.42 E+05$ & Toxicant \\
\hline$T-110$ & $3.79 \mathrm{E}+05$ & $2.53 E+09$ & $6.40 \mathrm{E}+\overline{0} 5$ & $6.40 E+05$ & Toxicant \\
\hline$T-111$ & $4.53 \mathrm{E}+05$ & $1.05 \mathrm{E}+09$ & $1.23 \mathrm{E}+09$ & $1.05 E+09$ & Cancer \\
\hline$T-112$ & $5.70 E+04$ & $4.74 E+07$ & $5.18 \mathrm{E}+05$ & $5.18 E+05$ & Toxicant \\
\hline$T-201$ & $2.90 \mathrm{E}+04$ & Not Ávailabl & $5.35 E+13$ & $5.35 E+13$ & Toxicant \\
\hline$T-202$ & $2.10 E+04$ & $2.47 \bar{E}+11$ & $4.84 E+05$ & $4.84 \mathrm{E}+0 \mathrm{D}$ & Toxicant \\
\hline $\bar{T}-203$ & $3.50 \mathrm{E}+04$ & $4.12 \mathrm{E}+10$ & $4.15 E+05$ & $4 . \overline{15 E}+\overline{C 5}$ & Toxicant \\
\hline$T-204$ & $3.80 \mathrm{E}+04$ & $2.76 \mathrm{E}+10$ & $3.09 \mathrm{E}+05$ & $3.09 E+05$ & Toxicant \\
\hline$\overline{T X}-101$ & $8.70 E+04$ & $3.29 E+06$ & $7.02 \bar{E}+04$ & $7.02 E+04$ & Toxicant \\
\hline $\mathrm{TX}-102$ & $2.17 \mathrm{E}+05$ & $8.64 \overline{E+05}$ & $6.74 \mathrm{E}+04$ & $6.74 E+04$ & Toxicant \\
\hline$T X-103$ & $1.57 \mathrm{E}+05$ & $2.67 E+06$ & $1.58 \mathrm{E}+0.5$ & $1.58 \mathrm{E}+0.5$ & Trexicant \\
\hline TX-104 & $6.50 E+04$ & $4.74 E+11$ & $6.12 E+04$ & $6.12 \bar{E}+04$ & Toxicant \\
\hline$T X-105$ & $6.09 E+05$ & $2.99 \mathrm{E}+05$ & $1.50 E+05$ & $1.50 \mathrm{E}+05$ & Toxicant \\
\hline $5 x-106$ & $4.53 \mathrm{E}+05$ & $1.50 E+06$ & $8.79 E+05$ & $8.79 \mathrm{E}+05$ & Toxicani \\
\hline$T X-107$ & $3.60 \mathrm{E}+\overline{\mathrm{O4}}$ & $3.62 \mathrm{E}+12$ & $1.39 E+05$ & $1.39 \mathrm{E}+05$ & Toxicant \\
\hline
\end{tabular}


Table B-3. Threshold Leakage Values for Each Tank. (sheet 3 of 3)

\begin{tabular}{|c|c|c|c|c|c|}
\hline Tank & Volume & Cancer LTV & Toxicant LT & LTV & Limiting \\
\hline & (gal) & (gal) & (gal) & (gal) & Factor \\
\hline TX-108 & $1.34 E+05$ & $1.69 E+05$ & $6.00 E+04$ & $6.00 \mathrm{E}+04$ & Toxicant \\
\hline $7 X-109$ & $3.64 E+05$ & $3.08 E+04$ & $4.94 E+04$ & $3.08 \mathrm{E}+04$ & Cancer \\
\hline$T X-140$ & $4.62 \mathrm{E}+05$ & $8.19 E+04$ & 1.11E+05 & $8.19 E+04$ & Cancer \\
\hline TX-111 & $3.70 E+05$ & $3.48 \mathrm{E}+05$ & $1.88 \mathrm{E}+05$ & $1.88 \mathrm{E}+05$ & Toxicant \\
\hline TX-112 & $6.49 E+05$ & $1.53 E+06$ & $1.74 E+05$ & $1.74 \mathrm{E}+05$ & Toxicant \\
\hline TX-113 & $6.07 E+05$ & $1,44 E+06$ & $1.91 \mathrm{E}+05$ & $1.91 E+05$ & Toxicant \\
\hline$T X-114$ & $5.35 \mathrm{E}+05$ & $1.16 \mathrm{E}+06$ & $4.62 \mathrm{E}+05$ & $4.62 \mathrm{E}+05$ & Toxicant \\
\hline TX-115 & $6.40 \mathrm{E}+05$ & $1.64 E+06$ & $2.59 E+05$ & $2.5 \overline{9 E}+05$ & Toxicant \\
\hline TX-116 & $6.31 \mathrm{E}+05$ & $4.53 \mathrm{E}+06$ & $9.81 E+04$ & $9.81 E+04$ & Toxicant \\
\hline TX-117 & $6.26 \mathrm{E}+05$ & $2.56 \mathrm{E}+06$ & $1.43 E+05$ & $1.43 E+05$ & Toxicant \\
\hline$T X-118$ & $3.47 E+05$ & $3.08 \mathrm{E}+04$ & $4.83 E+04$ & $3.08 \mathrm{E}+04$ & Cancer \\
\hline TY-101 & $1.18 E+05$ & $2.25 \mathrm{E}+06$ & $2.63 E+05$ & $2.63 E+05$ & Toxicant \\
\hline TY-102 & $6.40 E+04$ & $8.02 E+04$ & $2.99 \mathrm{E}+05$ & $8.02 E+04$ & Cancer \\
\hline TY-103 & $1.62 E+05$ & $1.81 \mathrm{E}+06$ & $4.63 E+05$ & $4.63 E+05$ & Toxicant \\
\hline$T Y-104$ & $4.60 \mathrm{E}+04$ & $6.02 E+05$ & $8.89 \mathrm{E}+05$ & $6.02 \mathrm{E}+05$ & Cancer \\
\hline TY- 105 & $2.31 \mathrm{E}+05$ & $6.76 E+05$ & $8.01 E+C 5$ & $6.76 \mathrm{E}+05$ & Cancer \\
\hline$\overline{T Y}-106$ & $1.70 \mathrm{E}+04$ & $2.19 \mathrm{E}+05$ & $5.95 E+05$ & $2.19 \mathrm{E}+05$ & Cancer \\
\hline $\mathrm{U}-101$ & $2.50 E+04$ & $1.06 \mathrm{E}+05$ & $7.71 E+07$ & $1.06 \mathrm{E}+05$ & Cancer \\
\hline U-102 & $3.74 E+05$ & $5.65 \mathrm{E}+05$ & $2.52 E+05$ & $2.52 \mathrm{E}+05$ & Toxicant \\
\hline U-103 & $4.68 \mathrm{E}+05$ & $3.24 \mathrm{E}+09$ & $1.83 E+05$ & $1.83 E+0.5$ & Toxicant \\
\hline U-104 & $1.22 \mathrm{E}+05$ & $1.02 \mathrm{E}+08$ & $1.69 \mathrm{E}+0 \mathrm{~S}$ & $1.02 \mathrm{E}+08$ & Cancer \\
\hline U-105 & $4.18 E+05$ & $1.14 \mathrm{E}+09$ & $1.94 \mathrm{E}+05$ & $1.94 \mathrm{E}+05$ & Toxicant \\
\hline U-106 & $2.26 E+05$ & $1.34 E+14$ & $2.35 E+05$ & $2.35 \mathrm{E}+05$ & Toxicant \\
\hline U-107 & $4.06 \mathrm{E}+05$ & $3.68 \mathrm{E}+05$ & $8.00 E+05$ & $3.68 \mathrm{E}+05$ & Cancer \\
\hline U-108 & $4.66 \mathrm{E}+05$ & $5.33 E+08$ & $1.73 E+05$ & $1 . \overline{3 E+05}$ & Toxicant \\
\hline U-109 & $4.63 E+05$ & $3.93 \mathrm{E}+06$ & $8.56 \mathrm{E}+05$ & $8.56 \mathrm{E}+05$ & Toxicant \\
\hline$U-110$ & $1.86 E+05$ & $7.88 \mathrm{E}+06$ & $1.49 E+05$ & $1.49 \mathrm{E}+05$ & Toxicant \\
\hline U-111 & $3.29 \mathrm{E}+05$ & $1.25 E+06$ & $1.38 \mathrm{E}+05$ & 1.38E+05 & Toxicant \\
\hline U-112 & $4.90 \mathrm{E}+04$ & $1.40 \bar{E}+05$ & $1.29 \mathrm{E}+05$ & $1.29 \mathrm{E}+05$ & Toxicant \\
\hline U-201 & $5.00 E+03$ & $8 . \overline{33 E+04}$ & $1.05 \mathrm{E}+05$ & $8.33 \mathrm{E}+04$ & Cancer \\
\hline $\mathrm{U}-202$ & $5.00 \mathrm{E}+03$ & $8.33 \mathrm{E}+04$ & $5.89 E+05$ & $8.33 \mathrm{E}+04$ & Cancer \\
\hline$\overline{\mathrm{U}-203}$ & $3.00 \mathrm{E}+03$ & $6.36 E+04$ & $5.47 \mathrm{E}+\overline{04}$ & $5.47 \mathrm{E}+04$ & Toxicant \\
\hline U-204 & $3.00 E+03$ & $2.49 E+05$ & $8.44 \mathrm{E}+04$ & $8.44 E+04$ & Toxicant \\
\hline
\end{tabular}




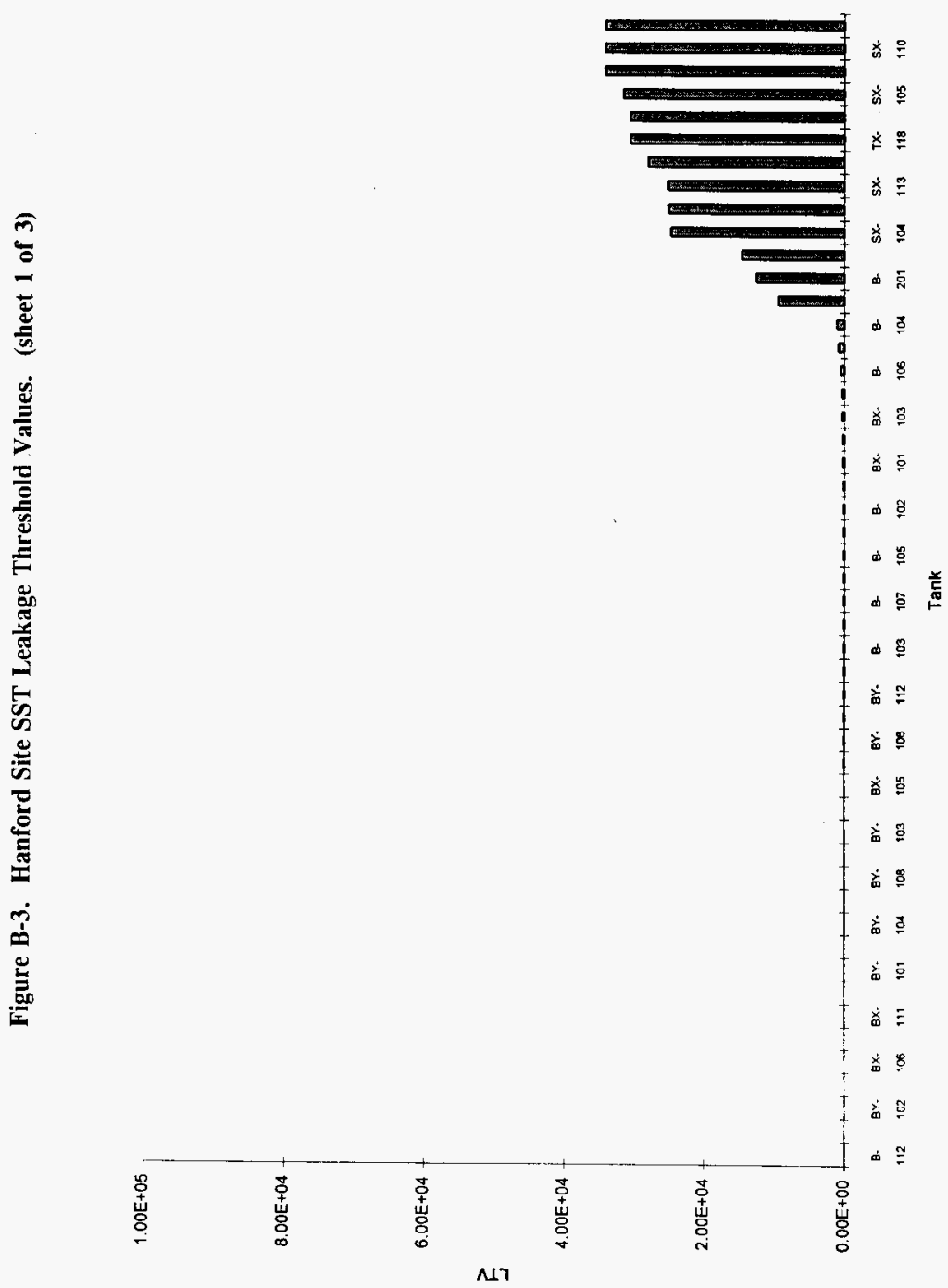




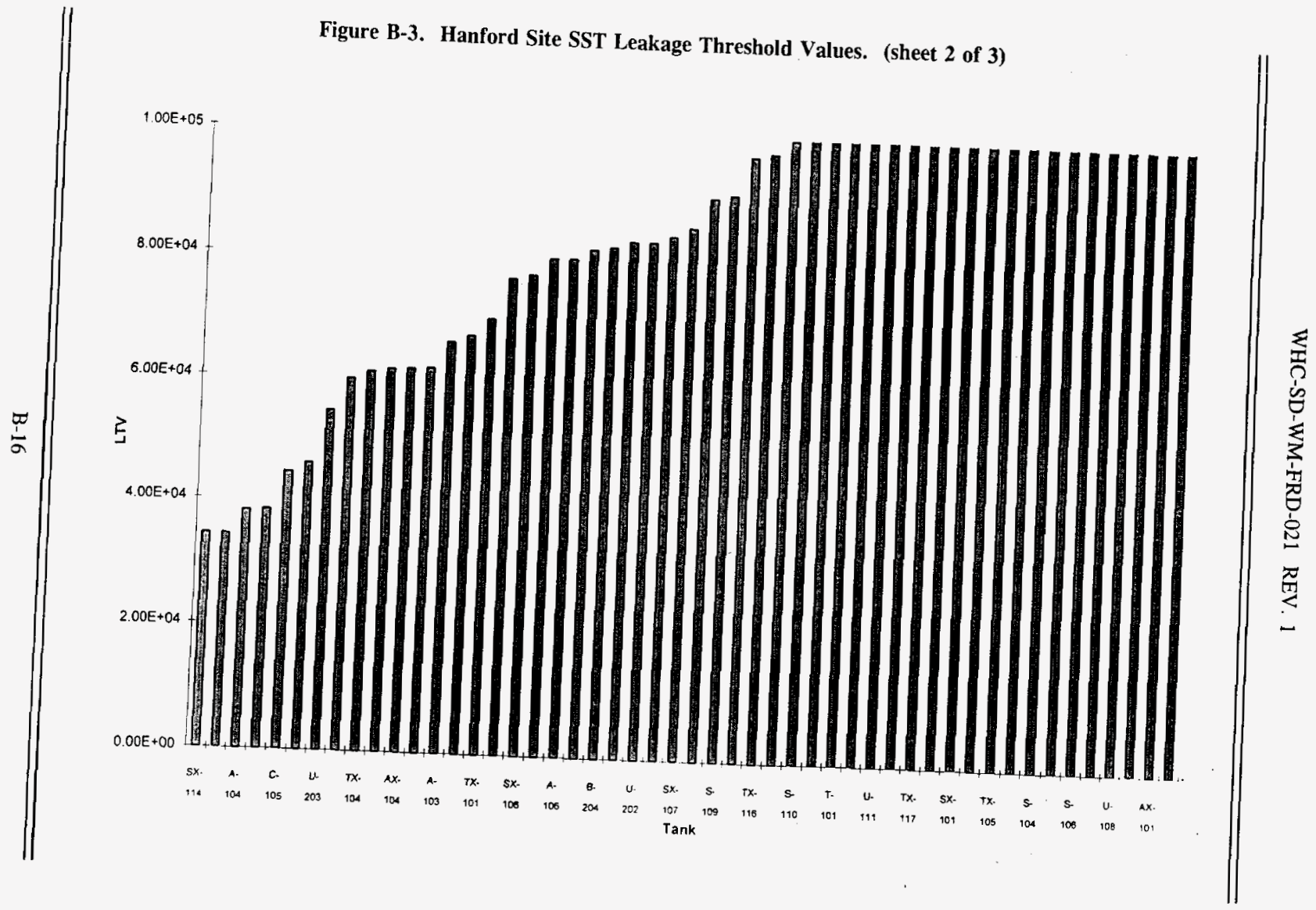




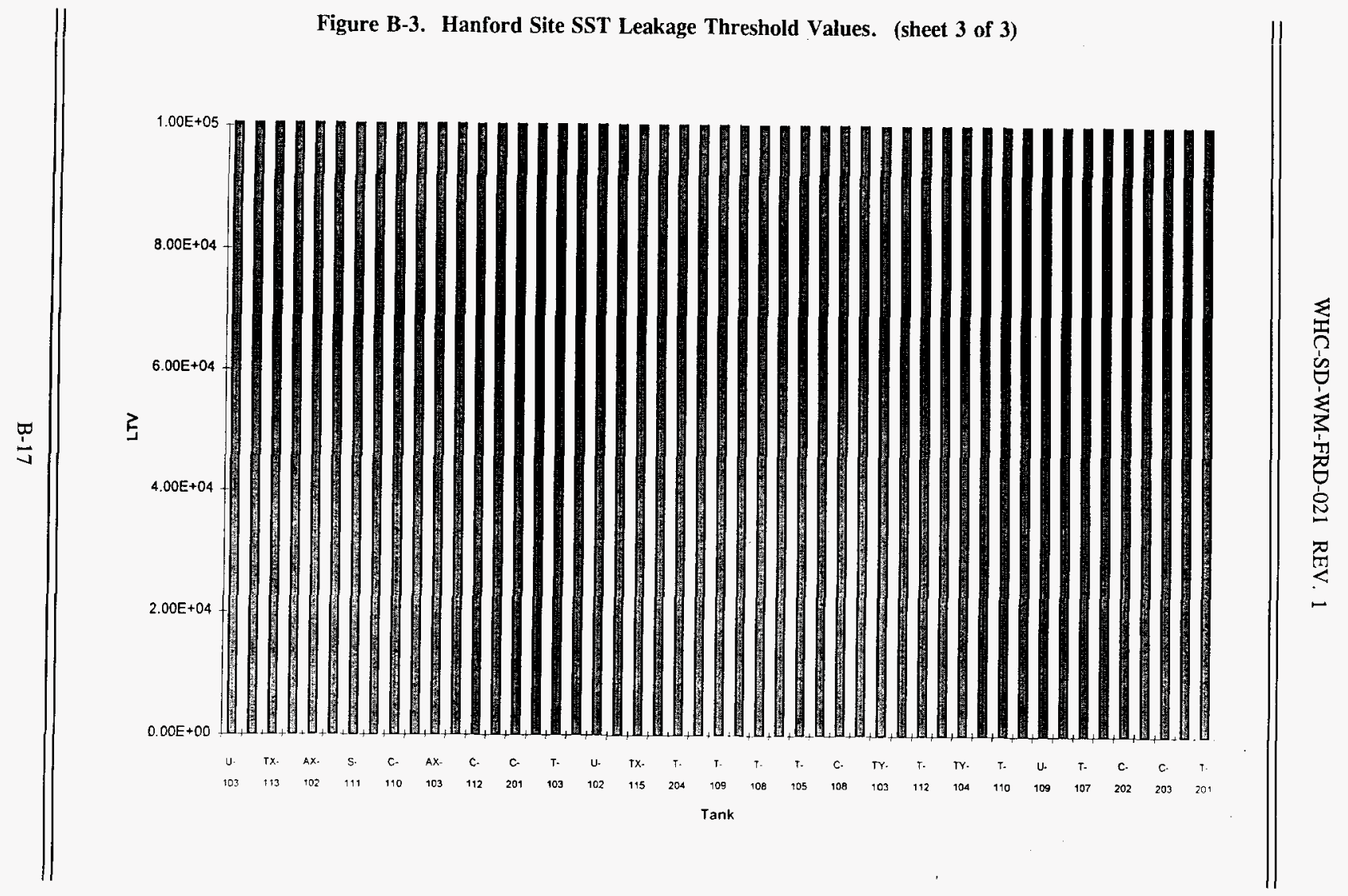


The LTVs developed in this report are examples and serve only as planning guidelines. While they build on the work performed in Revision 0 of this document, there remain other sources of risk that should be considered. These include residual waste that has advected into the tank concrete and contaminant plumes from cribs, trenches, and ponds. Additionally, it must be assumed that current data on past leakage are approximate or incomplete. Because variables such as the amount of waste heel remaining after retrieval and tank integrity during retrieval will change on a tank-by-tank basis and affect final LTV determinations, the LTVs presented in Table B-3 are considered to be qualitative; however these LTVs are useful for indicating that one tank may be more amenable to retrieval using past-practice sluicing than another tank.

The overall risk threshold levels assumed in the development of the LTVs are $1 \times 10^{-4}$ for carcinogens and 1.0 for toxicants. These thresholds were based on the upper limits of regulatory guidance for cleanup of hazardous waste sites under the Resource Conservation and Recovery Act and the Comprehensive Environmental Response, Compensation, and Liability Act. However, it can be argued that the LTVs should be reduced because there are other risk sources and uncertainties that are not included in this analysis. To investigate the impact of a conservative reduction, the LTV analysis was performed using risk thresholds of $1 \times 10^{-5}$ for carcinogens and 0.1 for toxicants. The LTVs for all tank farm groups were reduced to zero under this assumption. The impacts of the conservative risk threshold reduction are summarized in Table B-4.

Table B-4. Impacts of Overall Acceptable Risk Threshold

\begin{tabular}{|l|c|c|}
\hline \multicolumn{1}{|c|}{ Risk Thresholds } & $\begin{array}{c}\text { Number of Tanks with } \\
\text { LTV }<\mathbf{1 , 0 0 0} \text { gal }\end{array}$ & $\begin{array}{c}\text { Tank Farms LTV } \\
<\mathbf{1 , 0 0 0} \text { gal }\end{array}$ \\
\hline \hline $\begin{array}{l}\text { Carcinogenic Risk Threshold: } 1 \times 10^{-4} \\
\text { Toxicant Risk Threshold: } 1.0\end{array}$ & 37 & B Group (B, BX, BY) \\
\hline $\begin{array}{l}\text { Carcinogenic Risk Threshold: 1 } 1 \times 10^{-5} \\
\text { Toxicant Risk Threshold: 0.1 }\end{array}$ & 149 & All tank farm groups \\
\hline
\end{tabular}

\section{B.4.0 REFERENCES}

Droppo, J.G., D.L. Strenge, J.W. Buck, B.L. Hoopes, R.D. Brockhaus, M.B. Walter, and G. Whelan, 1991, Multimedia Environmental Pollutant Assessment System (MEPAS) Application Guidance, PNL-7216, Battelle-Pacific Northwest Laboratory, Richland, Washington.

Hanlon, B.M., 1996, Tank Farm Surveillance and Waste Status Summary Report for October 1995, WHC-EP-0182-91, Westinghouse Hanford Company, Richland, Washington. 
Serne, R.J. and M.I. Wood, May 1990, Hanford Waste Form Releases and Sediment Interactions, PNL 7297, Battelle Pacific Northwest Laboratories, Richland, Washington.

Treat, R.L, B.B. Peters, R.J. Cameron, W.D. McCormack, T. Trenkler, M.F. Walters, J.K. Rouse, T.J. McLaughlin, and J.M. Cruse, 1995, Feasibility Study of Tank Leakage Mitigation Using Subsurface Barriers, WHC-SD-WM-ES-300, Rev: 1, Westinghouse Hanford Company, Richland, Washington.

Van Vleet, R.J., 1993, Radionuclide and Chemical Inventories for the Single Shell Tanks, WHC-SD-WM-TI-565, Westinghouse Hanford Company, Richland, Washington. 
WHC-SD-WM-FRD-021 REV. 1

This page intentionally left blank. 
WHC-SD-WM-FRD-021 REV. 1

APPENDIX C

ITEMS NEEDING FURTHER RESOLUTION

C-i 
WHC-SD-WM-FRD-021 REV. 1

This page intentionally left blank. 


\section{APPENDIX C}

The functional decomposition and analysis reflected in this document required a number of assumptions to be made; also, a number of issues were identified. The issues, assumptions, and required analyses specific to leak detection, monitoring, and mitigation during retrieval of single-shell-tank (SST) waste are described in the following table.

\begin{tabular}{|c|c|}
\hline Issue or Enabling Assumption/Required Analyses & $\begin{array}{c}\text { Requirement or } \\
\text { Architecture }\end{array}$ \\
\hline $\begin{array}{l}\text { Time Frame. The leakage detection system shall be capable of detecting a leak within } \\
\text { a time frame that allows for operational response. } \\
\text { Required Analysis } \\
\text { In conjunction with the Hanford Site Systems Engineering approach, } \\
\text { development and documentation of quantitative requirements for the time frame } \\
\text { and accuracy of leakage detection during retrieval of SST waste will need to be } \\
\text { performed, on a tank-by-tank basis, prior to the stan of sluicing a tank. } \\
\text { Parameters needing to be determined include, but are not limited to, the } \\
\text { minimum volume of leakage to be detected. }\end{array}$ & 4.2.2.1.1 P1 \\
\hline $\begin{array}{l}\text { Reliability } \\
\text { The system shall be capable of detecting leakage with an acceptable probability of } \\
\text { detection and a minimal probability of false alarm. } \\
\text { Required Analysis } \\
\text { In conjunction with the Hanford Site Systems Engineering approach, } \\
\text { development and documentation of quantitative requirements for the reliability } \\
\text { of the system during retrieval of SST waste will need to be performed. }\end{array}$ & $\begin{array}{l}4.2 .2 .1 .1 \mathrm{P} 2 \\
4.2 .2 .1 .2 \mathrm{P} 2\end{array}$ \\
\hline $\begin{array}{l}\text { External Deployment } \\
\text { If deployed external to the tank, the system shall be capable of deployment in the soils } \\
\text { surrounding the SSTs. } \\
\text { Required Analysis } \\
\text { In conjunction with the Hanford Site Systems Engineering approach. } \\
\text { identification and documentation of physical restrictions for the deployment of } \\
\text { extermal systems during retrieval of SST waste will need to be perforned on a } \\
\text { tank-by-tank basis. }\end{array}$ & $\begin{array}{l}4.2 .2 .1 .1 \mathrm{P} 4 \\
4.2 .2 .1 .2 \mathrm{P} 3 \\
4.2 .2 .1 .3 \mathrm{P} 2\end{array}$ \\
\hline $\begin{array}{l}\text { In-Tank Operation } \\
\text { If deployed in-tank, the system shall be capable of surviving/functioning under current } \\
\text { and planned in-tank physical conditions. } \\
\text { Required Analysis } \\
\text { In conjunction with the Hanford Site Systems Engineering approach, } \\
\text { development and documentation of physical and radiological conditions for the } \\
\text { operation of an internal system, for use during retrieval of SST waste, will } \\
\text { need to be performed on a tank-by-tank basis. }\end{array}$ & $\begin{array}{l}4.2 .2 .1 .1 \text { P5 } \\
4.2 .2 .1 .3 \text { P3 }\end{array}$ \\
\hline
\end{tabular}


WHC-SD-WM-FRD-021 REV. 1

\section{Issue or Enabling Assumption/Required Analyses}

External Operation

If deployed external to the tank, the system shall be capable of withstanding the physical and radiological conditions of the subsurface environment.
Requirement or Architecture

4.2.2.1.1 P6

4.2.2.1.2 P4

4.2.2.1.3 P4

\section{Required Analysis}

In conjunction with the Hanford Site Systems Engineering approach, development and documentation of physical and radiological conditions for operation of an external system, for use during retrieval of SST waste, will need to be performed.

Enabling Assumption - Retrieval Method

Retrieval of the SST waste will be conducted using traditional past-practice sluicing as the primary approach.

A4.2.2.1.1

A4.2.2.1.2

A4.2.2.1.3

\section{Required Analysis}

The method for retrieval for each of the SSTs will need to be determined on a tank-by-Iank basis, and the architecture for LDMM given in this document will need to be refined as necessary.

\section{Enabling Assumption - Tank Farm Closure}

The SST Tank Farms will be closed as landfills with appropriate closure and post-closure supporting activities. It is further assumed that the basic closure methodology will consist of structurally stabilizing the tanks (residual remaining in

place) followed by installation of a protective surface barrier.

\section{Required Analysis}

Baseline closure conditions of the SST Tank Farms will need to be established and documented. The architecture for leakage detection during retrieval of SST waste could be impacted significantly by the level of closure. 


\section{DISTRIBUTION SHEET}

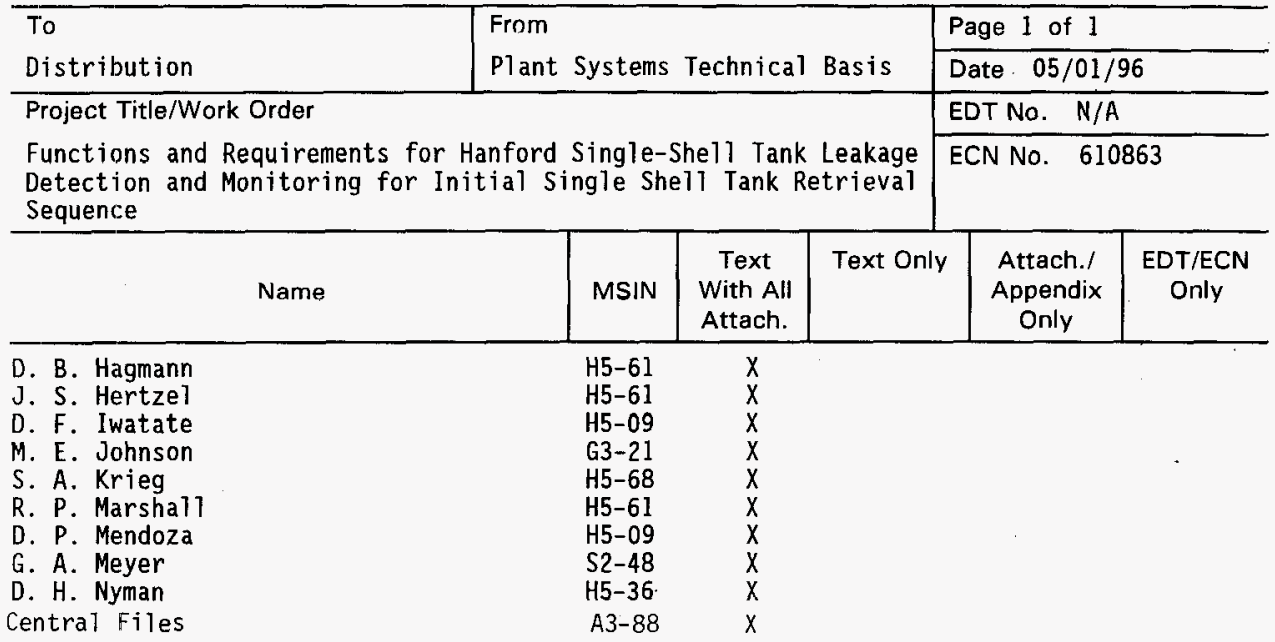

